\title{
CEREMONIA Y CONFLICTO: ENTRADAS REALES EN BARCELONA EN EL CONTEXTO DE LA GUERRA CIVIL CATALANA $(1460-1473)^{1}$
}

\author{
CEREMONY AND CONFLICT: \\ ROYAL ENTRIES IN BARCELONA \\ IN THE CONTEXT OF THE CATALAN CIVIL WAR \\ (1460-1473)
}

\author{
Miguel Raufast Chico \\ Institución Milà y Fontanals \\ CSIC, Barcelona
}

\begin{abstract}
Resumen: Este estudio recorre las ceremonias de entrada real que se celebraron en Barcelona, entre 1460 y 1473, a la luz de su significación y trascendencia en relación al conflictivo período marcado por la Guerra Civil Catalana (1462-1472). Partiendo de la premisa de que este tipo de eventos son susceptibles de reflejar la realidad sociopolítica en la que tienen lugar, se intenta aquí determinar en qué medida las recepciones ofrecidas por la ciudad a la monarquía durante estos años pueden contribuir a explicar la génesis, desarrollo y conclusión del conflicto bélico que enfrentó a las instituciones del Principado con Juan II.
\end{abstract}

Palabras clave: Entrada real; Ceremonia; Conflicto; Barcelona; Guerra Civil Catalana; Siglo XV.

\begin{abstract}
This study examines the royal entry ceremonies celebrated in Barcelona between 1460 and 1473, in the light of their meaning and importance in relation to the unsettled period marked by the Catalan Civil War (1462-1472). Starting from the premise that these sort of events are likely to reflect the sociopolitical reality in which they occur, it sets out to determine just how far the receptions offered to the monarchy by the city during these years can contribute towards explaining the origin, development and conclusion of the warlike conflict which set the institutions of the Principate against John II.
\end{abstract}

Keywords: Royal Entry; Ceremony; Conflict; Barcelona; Catalan Civil War; 15th Century.

${ }^{1}$ Este trabajo se inscribe en el marco del Proyecto de Investigación aprobado y financiado por la DGCYT: "La Corona de Aragón en el Mediterráneo medieval: puente entre culturas, mediadora entre Cristiandad e Islam" (HUM2007-61131), dirigido por la Dra. Roser Salicrú Lluch.

Quiero agradecer la valiosa colaboración de Esther Redondo e Iván Armenteros en la elaboración y diseño del plano que acompaña este artículo.

Abreviaturas utilizadas: ACA $=$ Archivo de la Corona de Aragón; $\mathrm{ACB}=$ Archivo de la Catedral de Barcelona; $\mathrm{AHCB}$ = Archivo Histórico de la Ciudad de Barcelona; $\mathrm{AMLl}=$ Archivo Municipal de Lleida; ARV = Archivo del Reino de Valencia; $B C=$ Biblioteca de Cataluña; $C$ $=$ Cancilleria; $\mathrm{CC}=$ Consell de Cent; CODOIN = Colección de Documentos Inéditos del Archivo de la Corona de Aragón; f., ff. = folio, folios; Ms = Manuscrito; r = recto; reg. = registro; $\mathrm{s}$. f. $=$ sin foliar; $\mathrm{v}=$ verso 


\section{SUMARIO}

1. Introducción.- 2. Ceremonia y conflicto.- 3. La entrada real como conflicto (1460-1461).4. El conflicto y sus ceremonias (1462-1471).- 5. Ceremonias para después de una guerra (1472-1473).- 6. Conclusión.

\section{INTRODUCCIÓN}

Entre 1416 y 1458 , es decir, el período del reinado de Alfonso el Magnánimo en la Corona de Aragón, Barcelona apenas tuvo ocasión de celebrar ceremonias solemnes de recepción con motivo de las entradas de la monarquía. En realidad, tras la modesta primera entrada de Alfonso como nuevo soberano en 1416 -condicionada por la muerte todavía reciente de su padre, Fernando I- y la acogida con la que se festejó, en 1423, su regreso a la ciudad después del fracaso inicial de la aventura napolitana, no puede hablarse de experiencia ceremonial alguna que merezca el calificativo de entrada real. La permanente ausencia del monarca desde 1432, instalado ya para siempre en tierras italianas, así como la inexistencia, en todo ese tiempo, de un primogénito al trono, acabó limitando drásticamente las posibilidades expresivas del municipio en dicho sentido. Como consecuencia de ello, mientras la entrada triunfal de Alfonso el Magnánimo en Nápoles, en 1443, casi ha alcanzado rango de paradigma ceremonial ${ }^{2}$, poco puede destacarse, sin embargo, de las estrictamente protocolarias recepciones con las que, en estos años, Barcelona solemnizó algunas de las visitas de la reina María, esposa del monarca, o del futuro Juan II, hermano de Alfonso y rey de Navarra, ambos desempeñando la lugartenencia general en Cataluña ${ }^{3}$.

Por el contrario, tan sólo en los 15 primeros años del reinado de Juan II, desde 1458 hasta 1473, los habitantes de dicha ciudad fueron testigos de no menos de ocho entradas reales, en su mayoría de gran trascendencia, no sólo para la vida de la propia Barcelona, sino para todo el conjunto del Principado. Tal desproporcionada acumulación ceremonial -comparada, especialmente, con lo sucedido en los 50 años anteriores- se concentró, de forma significativa, en torno a un período tumultuoso, inestable y altamente conflictivo como fue el que caracterizó a los preámbulos, desarrollo y conclusión de la Guerra Civil Catalana (1462-1472). Así, tras la celebración

\footnotetext{
${ }^{2}$ Véanse, al respecto, los trabajos de Hope MAXWELL SNYDER, Triumphs and Pageants at the Aragonese Court in Naples, "Atalaya", 7 (1996), pp. 41-62, y de Francesc MASSIP, De ritu social a espectacle del Poder: l'Entrada triomfal d'Alfons el Magnànim a Nàpols (1443), entre la tradició catalana $i$ la innovació humanística en XVI Congresso Internazionale di Storia della Corona d'Aragona (Napoli, Caserta, Ischia,1997), 2 vols., Napoli, 2000, vol. II, pp. 1859-1889.

${ }^{3}$ Señalemos, a título de ejemplo, la que se efectuó en 1446, con motivo de la llegada de la reina a Barcelona, tal como ha quedado recogida en la recopilación archivística realizada, en el siglo XVI, por Pere Joan CoMES, Libre de coses asanyalades (Barcelona, 1878, p. 117); o la que tuvo lugar,, en 1454, en honor del rey de Navarra, durante su entrada en la ciudad como nuevo lugarteniente general en Cataluña, según consta en el Llibre de les Solemnitats de Barcelona (eđición de Agustí DURAN I SANPERE y Josep SANABRE, 2 vols., Barcelona, 1930-1947, vol. I, pp. 208-209).
} 
inaugural con la que Barcelona distinguió la primera visita de Juan II, como nuevo soberano de la Corona de Aragón, y de su esposa, la reina Juana, en noviembre de 1458, la cadencia ceremonial de la ciudad en relación a este tipo de eventos pasó a intensificarse de manera inesperada. Las graves diferencias entre el monarca y su primer hijo, el príncipe de Viana, con el tema de la primogenitura real como telón de fondo; el desencuentro político y posterior enfrentamiento armado entre las instituciones catalanas y Juan II; y la azarosa desaparición de algunos de los principales personajes designados por el Principado para sustituir a dicho rey en el trono, dieron pie a que, entre 1460 y 1473, las recepciones solemnes ofrecidas a la monarquía por parte de la ciudad de Barcelona cobrasen una intensidad y adquiriesen una repercusión desconocidas hasta la fecha. Algunas de ellas contribuyeron a incentivar el conflicto, y otras sirvieron para escenificar su conclusión, mientras que todas, en su conjunto, llegaron a expresar -en tanto que reflejo incuestionable- la realidad política del Principado en dicho período.

Son estas entradas reales, así como el fragmento de historia que contienen en su interior, las que se intentará analizar en el presente trabajo. Su estudio nos ha de permitir no únicamente relacionar ceremonia y conflicto en sus diferentes variantes, sino profundizar algo más en la tradición y los modelos celebrativos de recepción de la Barcelona del siglo $\mathrm{XV}^{4}$, al mismo tiempo que nos adentramos en los años de una Guerra Civil Catalana que, a pesar de su dimensión histórica, de su complejo desarrollo, y de lo, hasta cierto punto, insólito de algunos de sus rasgos definitorios, continúa presentando, a día de hoy, un gran déficit a nivel historiográfico ${ }^{5}$.

\footnotetext{
${ }^{4}$ Para una aproximación al tema de la entrada real en lạ Barcelona bajomedieval, véanse Lenke KoVACS, La ciutat com a escenari: les entrades reials $i$ la festa urbana, "Barcelona. Quaderns d'Història", 9 (2003), pp. 71-82; Kenneth KREITNER Music and Civic Ceremony in Late Fifteenth-Century Barcelona. Tesis doctoral inédita, Duke University, 1990; Miguel RAUFAST CHICO, Negociar la entrada del rey? La entrada real de Juan II en Barcelona (1458), "Anuario de Estudios Medievales", 36/1 (2006), pp. 295-333; IDEM, "E vingueren los officis e confraries $a b$ llurs entremeses e balls". Una aproximación al estamento artesanal en la Barcelona bajomedieval, a partir del estudio de las ceremonias de entrada real, "Anuario de Estudios Medievales", 36/2 (2006), pp. 651-686; IDEM, ¿Una misma ceremonia para dos dinastías? Las entradas reales de Martín el Humano (1397) y Fernando I (1412) en Barcelona, "En la España Medieval", 30 (2007), pp. 91-129; IDEM, La entrada real de Martín el Joven, rey de Sicilia, en Barcelona. (1405): Solemnidad. economía y conflicto, "Acta Historica et Archaeologica Mediaevalia", 27 (2006-2007), pp. 89-119; IDEM, Imágenes para una ceremonia: la entrada real en la Barcelona bajomedieval, en Gemma Teresa COLESANTI (ed.), Le usate leggiadrie. I cortei, le cerimonie, le feste e il costume nel'Mediterraneo tra XV e X'VI secoli, Montella, 2008 (en prensa); IDEM, ¿Recibir al primogénito? Política y ceremonia en las entradas del príncipe de Viana en Barcelona (1460 y 1461), en Eloisa RAMÍREZ VAQUERO; Roser SALICRÚ I LLUCH (eds.), Navarra y la Corona de Aragón en la Edad Media (en prensa).

${ }^{5}$ Tal como ha vuelto a poner de manifiesto la reciente aparición del libro de Alan RYDER, The Wreck of Catalonia. Civil War in the Fifteenth Century, Oxford, 2007. En su introducción, el autor no duda en mostrar su sorpresa ante la escasa atención prestada por la historiografía catalana a dicho conflicto, señalando cómo, tras la publicación, en 1973, de la obra de Santiago Sobrequés y Jaume Sobrequés, La guerra civil catalana del segle XV, la investigación sobre el tema parece haber quedado abandonada. Aunque la afirmación de Ryder sea, quizás, excesivamente drástica, lo que resulta innegable es que no existe ninguna obra básica de refêrencia sobre este asunto realizada con posterioridad al título mencionado. Ofrecemos aquí una lista, a efectos meramente ilustrativos, de la cronología de dicha producción: Joseph CALMETTE, Louis XI, Jean II et la révolution catalane (1461-1473), Geneve, 1977 (edición original de 1902); Antoni RovIRA I VIRGILI, Història Nacional de Catalunya, vol. VI, Barcelona, 1931, pp. 496-596; Jaume SOBREQUÉS I VIDAL, Los orígenes de la Revolución catalana del siglo XV Hestudios de Historia Moderna", II (1952), pp. 3-96; Jaume VICENS VIVES, Juan II de Aragón (1398-1479). Monarquía
} 
Siempre desde la perspectiva de la ceremonialidad urbana -es decir, potenciando la interpretación de la entrada real como una manifestación más de la fuerte ritualidad cívica que caracteriza al municipio bajomedieval y a sus instituciones ${ }^{6}-$, dicho período presenta, además, un interés añadido. La inseguridad inherente a todo estado de confrontación bélica, la precaución frente a la amenaza exterior e, incluso, la desconfianza respecto a la debilidad interior, elevaron exponencialmente, durante la duración del conflicto, la conciencia del municipio barcelonés como espacio amurallado susceptible de devenir hermético. El obsesivo control de los portales de la ciudad establecido por el gobierno consistorial, la capacidad para graduar los filtros de acceso al recinto urbano en función de las necesidades de cada momento, y las estrictas medidas destinadas a garantizar la defensa de Barcelona frente al ataque del enemigo proporcionan un marco privilegiado -a través de su excepcionalidad y aparente sentido paradójico- para el estudio de una ceremonia que responde al nombre de "entrada" y que fundamenta su existencia en el tránsito solemne entre el exterior y el interior de todo núcleo urbano. Así, entre 1460 y 1473, los grandes momentos de apertura ritual de la ciudad de Barcelona se alternaron -cuando no convivieron estrechamente- con movimientos opuestos de retracción, en lo que podríamos calificar de verdadero discurso gestual que, trascendiendo el contexto político y militar, afectaba la esencia orgánica del propio municipio. Dicha particularidad nos ha de permitir, en último extremo, poder apreciar con especial nitidez el alcance -real y simbólico- de la relación diferencial, no siempre armoniosa, entre los espacios que separa la muralla urbana; un aspecto que, a pesar de formar parte del sentido básico

y revolución en la España del siglo XV, Barcelona, 1952 (edición actualizada en Pamplona, 2003); Santiago SOBREQUÉS I VIDAL y Jaume SOBREQUÉS I CALLICÓ, La guerra civil catalana del segle XV, 2 vols., Barcelona, 1973; Manuel J. PELÁEZ ALBENDEA, La actuación político-militar de Hugo Roger III de Pallars durante la guerra civil de 1462-1472, Barcelona, 1975. Ramón ROSSELló I VAQUER, La revolta menorquina contra Joan II (1463-1472), Palma, 1981; Prim BERTRAN I ROIGÉ, Târrega en la revolta catalana contra Joan II, "Ilerda", 43 (1982), pp. 359375; Bernard DOUMERC, Les Vénitiens dans la tourmente de la guerre civile en Catalogne (14621472), "Le Moyen Age", 101 (1995), pp. 41-63; Assumpta SERRA I CLOTA, Anàlisi de la guerra civil catalana (1462-1472) a partir de les actuacions locals, en Enfrontaments civils: postguerres $i$ reconstruccions (Segons Congrés Recerques, Lleida, 2002), 2 vols., Lleida, 2002, vol. I, pp. 83-103; Jaume SOBREQUÉS I CALLICÓ, Extraterritorialitat del poder polític del Consell de Cent durant la guerra civil catalana del segle XV, en XVII Congrés d'Historia de la Corona d'Aragó (Barcelona, Poblet, Lleida, 2000), Barcelona, 3 vols., 2003, vol. III, pp. 923-934.

${ }^{6}$ Acerca de la importancia del ritual cívico bajomedieval, son de obligada referencia los trabajos ya clásicos de Richard Trexler y de Edward Muir sobre las ciudades de Florencia y Venecia, respectivamente: Richard C. TREXLER, Public Life in Renaissance Florence, New YorkLondon, 1980; Edward MuIR, Civic Ritual in Renaissance Venice, Princeton, 1981. En el mismo sentido, son igualmente destacables, entre otras, las aportaciones de Jacques RosSIAUD, Les rituels de la fête civique à Lyon, XIIe-XVIe siècles, en Jacques CHIFFOLEAU; Lauro MARTINES; Agostino PARAVICINI (eds.), Riti e rituali nelle società medievali, Spoleto, 1994, pp. 285-307; Peter ARNADE, Realms of Ritual. Burgundian Ceremony and Civic Life in Late Medieval Ghent, Ithaca-London, 1996; y Elodie LECUPPRE-DESJARDIN, La ville des cérémonies. Essai sur la comunication politique dans les anciens Pays-Bas bourguignons, Turnhout, 2004. Para una interesante matizacion sobre la ceremonialidad cívica urbana frente a las ceremonias de la realeza, véanse David NICHOLAS, In the Pit of the Burgundian Theater State. Urban Traditions and Princely Ambitions in Ghent, 1360-1420, en Barbara HANAWALT; Kathryn L. REYERSON (eds.) City and Spectacle in Medieval Europe, Minneapolis, $1994, \mathrm{pp} .271-295$. Francesco SENATORE, Cerimonie regie e cerimonie civiche a Capua (secoli XV-XVI), en Giovanna PETTI BALBI; Giovanni VITOLO (eds.), Linguaggi e pratiche del potere. Genova e il Regno di Napoli tra Medioevo ed Età moderna, Salerno, 2007, pp. 151-205. 
de la entrada real bajomedieval, no parece haber recibido toda la atención que merecería a la hora de analizar este tipo de ceremonias ${ }^{7}$.

\section{CEREMONIA Y CONFLICTO}

En 1451, dos conflictos surgidos, de manera casi simultánea, en las localidades de Tàrrega y Castelló d'Empúries reclamaron la intervención de las autoridades barcelonesas ${ }^{8}$. En tanto que detentadores, en nombre del propio municipio de Barcelona, de la jurisdicción señorial sobre dichas poblaciones, los consellers ${ }^{9}$ tuvieron que mediar en la resolución de dos situaciones de abierto enfrentamiento institucional que, a pesar de sus diferentes circunstancias, compartían un rasgo común: en ambas, la expresión del conflicto aparecía ligada, en mayor o menor medida, a lo ceremonial. Si nos detenemos un instante en ellas es, precisamente, por lo que de ilustrativo tienen -tanto por sí mismas como por su casual coincidencia temporal-para lo que aquí se pretende tratar.

Así, a inicios de febrero de 1451, los ediles barceloneses habían compartido con un reducido consejo de señalados miembros de la oligarquía municipal el contenido de sendas cartas que, enviadas por el obispo de Vic y

${ }^{7}$ El concepto de espacio "sacro-politizado" esgrimido por Nilda Guglielmi para referirse al interior de la ciudad bajomedieval comienza, precisamente, por la diferenciación que, mediante puertas y murallas, se establece con respecto al espacio exterior. Véanse, para esta cuestión, Nilda GUGLIELMI, L'image de la porte et des enceintes d'aprés les chroniques du Moyen Age (Italie du Nord et du Centre), en Jacques HEERS (comp.), Fortifications, portes de villes, places publiques, dans le monde méditerranéen, París 1985, pp. 103-120; EADEM, Muros y puertas en el paisaje urbano (Italia del centro y del norte. Siglos XIII-XV), "Acta Historica et Archaeologica Mediaevalia", 9 (1988), pp. 333-359; José Luis CORRAL LAFUENTE, Significado y símbolo de la ciudad medieval: elementos semióticos en el mundo urbano de Europa occidentál (1350-1550), "Revista de Historia Jerónimo Zurita", 56 (1987), pp. 131-160. Por lo que se refiere a la entrada real, Ana Isabel Carrasco ha relacionado el concepto de "rito de paso", elaborado por el antropólogo Arnold Van Gẹnepe, con estas ceremonias, al considerar que su materialización escenifica desde la separación inicial entre visitante y comunidad receptora -murallas, puertas cerradas- hasta la integración final del primero - celebración solemne de su llegada-, pasando por las fases intermedias de tensión y desconfianza que preceden dicha aceptación -negociación de los términos que marcarán el desarrollo del evento (véase Ana Isabel CARRASCO MANCHADO, Símbolos y ritos: el conflicto como representación, en José Manuel NIETO SORIA (dir.), La monarquía como conflicto en la Corona castellano-leonesa (c. 1230-1504), Madrid, 2006, pp. 489-546, y especialmente las pp. 539-544). Para una perspectiva similar, véanse también Gerritt JASPER SCHENK, Enter the Emperor. Charles IV and Siena Between Politics, Diplomacy, and Ritual (1355 and 1386), "Renaissance Studies" 20/2 (2006), p. 171; Edward MuIR, Fiesta y rito en la Europa Moderna, Madrid, 2001, pp. 301-305.

${ }^{8}$ En esta época, tanto Tàrrega como Castelló d'Empúries pertenecían a la ciudad de Barcelona. En 1391, el infante Martín, para poder financiar su expedición a Sicilia, había vendido Tàrrega, junto a otras localidades como Sabadell, Terrassa, Elx y Crevillent, al municipio barcelones. Posteriormente, en 1409, el propio Martín, ạhora ya como rey de la Corona de Aragón, había empeñado Castelló d'Empúries a dicho municipio en garantía del préstamo concedido por éste para la guerra de Cerdeña. Para más detalles acerca del dominio de Barcelona sobre estas dos poblaciones, véanse Josep Maria SEGARRA I MALLA, Història de Tàrrega, 3 vols. Tàrrega, 19842005, vol. I, pp. 229-317; Enrique RIERA FORTIANA, Etapa barcelonesa del Condado de Ampurias (1409-1456), "Annals de l'Institut d'Estudis Empordanesos", 1976, pp. 259-285. Igualmente, sobre las diferentes formas de incorporación de municipios a la jurisdicción de la I CALliCó, Història de Barcelona, 9 vols., Barcelona, 1991-1997, vol. İII, pp. 361-368.

${ }^{9}$ Magistrados supremos del gobierno de la çiudad, elegidos anualmente entre los miembros integrantes del Consell de Cent, máximo organismo rector del municipio barcelonés. 
por el procurador de Barcelona en el Condado de Empúries, ponían en conocimiento del consistorio los altercados que habían tenido lugar, respectivamente, en Tàrrega y en Castelló d'Empúries ${ }^{10}$.

En la primera de ellas -siguiendo el orden en el que fueron abordadas en la mencionada reunión- se denunciaba la extraña situación en la que se hallaban los miembros del clero de Tàrrega, puesto que, tras haber salido del recinto urbano en ceremonial procesión, como cada fin de año, con destino al cercano monasterio del Carmen, a su regreso se habían encontrado con las puertas de la villa cerradas y con la rotunda negativa de las autoridades civiles a volver a abrirlas para permitir su reingreso en ella. Según exponía el obispo de Vic en su misiva, los regidores de Tàrrega habían recurrido a dicha medida de fuerza para obligar al estamento eclesiástico a reducir los intereses que, en ese momento, cobraba sobre la deuda a largo plazo (censales) emitida por el municipio. No contentos con ello -se condenaba también en la carta-, los pahers habían llegado a forzar la sacristía de la iglesia mayor y habían permitido que, aún estando la villa en entredicho, se oficiasen misas dentro de sus murallas, mientras el clero era obligado a permanecer fuera de las mismas $^{11}$. Ante lo anómalo -nos atreveríamos a añadir que casi surrealistade la situación, el obispo de Vic acababa solicitando a los consellers barceloneses que hicieran uso, con urgencia, de su autoridad para que las cosas pudieran volver rápidamente a su cauce normal.

Tras la lectura de la carta, los participantes en la reunión consistorial habían pasado a examinar, de forma casi inmediata, el documento procedente de Castelló d'Empúries. En él, el procurador del Condado hacía un detenido relato del conflicto protocolario que había enfrentado a los representantes de la ciudad de Barcelona con las autoridades locales durante el desarrollo de una procesión en la iglesia mayor de la villa. Según se exponía en dicha relación, un inicial desacuerdo acerca del lugar a ocupar por parte de uno de los oficiales barceloneses en la comitiva procesional había acabado perturbando profundamente la ceremonia -hasta el punto que gran parte de la representación municipal se había negado a participar en ella- y, como consecuencia de ello, había llegado, incluso, a afectar a la convivencia política de la localidad, puesto que el batlle de Castelló d'Empúries, uno de los principales implicados en el altercado, había acabado momentáneamente, por disposición del

\footnotetext{
${ }^{10}$ La carta del obispo de Vic - a cuya diócesis pertenecía, en aquellos momentos, la villa de Tàrrega- había sido redactada el 6 de febrero de 1451 (AHC'B, CC, Lletres comunes originals, $\mathrm{X}-21$, f. 21r), mientras que la del procurador del Condado de Empúries llevaba fecha del 3 de febrero de 1451 (ibídem, f. 20r-v). La reunión de las autoridades barcelonesas en la que se debatió sobre estos asuntos tuvo lugar el 9 de febrero de 1451 (AHCB, CC, Deliberacions, II-17, ff. $16 \mathrm{v}-17 \mathrm{r})$.

${ }^{11}$ «com, alguns dies passats, lo clero de la dita vila era anat, per un cap d'any, al monastir del Carme, qui és fora la dita vila, e, quant volgué entrar en la dita vila, los portals foren tancats, que no'ls lexaren entrar en la dita vila. E que los pahers han fet obrir en la sacristía e n'an tret ço que s'an volgut, e han feta celebrar missa e fer offici en temps d'entradit. E tot acò és estat fet per tant com lo dit clero no vol reducir los censals que reeben sobre la dita vila al for que la dita vila volria» (ibidem, f. 16v).
} 
procurador barcelonés, entre rejas ${ }^{12}$. Por dicho motivo, y tras anunciar que ya había tomado las primeras medidas para depurar responsabilidades por lo sucedido en la frustrada ceremonia, el procurador ponía en manos de los consellers la decisión final a tomar sobre el conflicto ${ }^{13}$.

Portales cerrados, ceremonias convulsas, divergencias institucionales, desacuerdos protocolarios. En un instante, a lo largo de una misma sesión consistorial, el conflicto y su escenificación, así como la relación entre ceremonia y conflicto, habían desfilado -casi en visión panorámica- ante las autoridades barcelonesas. Y, sin embargo, nada de todo ello pudo resultar excesivamente sorprendente a los ojos de los consellers y los miembros de su consejo asesor, puesto que se trataba, en definitiva, de situaciones vividas, una y otra vez, por parte de cualquier comunidad urbana bajomedieval.

En cierto modo, el caso de Tàrrega no es, de hecho, más que la manifestación extrema -y un tanto paródica- de una realidad habitual que nos llevaría a contemplar el acceso físico y la permanencia en el interior de todo recinto urbano bajomedieval como el resultado de una negociación. En definitiva, tanto el mercader como el viajero, tanto aquél que aspira a ser un día ciudadano de pleno derecho como aquél que ya hace tiempo que lo es, tanto los extraños como los conocidos, y por supuesto, también el rey y su corte, necesitan, para poder entrar en la ciudad -y, en ocasiones, también para salir de ella-, ofrecer alguna garantía, establecer un compromiso previo, aceptar el cumplimiento de unas normas ineludibles (que van desde lo económico hasta lo espiritual $)^{14}$. El lenguaje cotidiano de las puertas, que, como prolongación de la voluntad de las autoridades municipales, segrega,

\footnotetext{
${ }^{12}$ «com, lo die de madona Sancta Maria prop passat del present mes de febrer, segons és acustumat, se fahia processó dins la esglèya major de la dita vila, e mister Galceran Torró, asesor del dit procurador, se fou mès aprés del vaguer, e lo batle li dix que aquell loch no era del dit asesor, que ans era del dit batle, e tirà lo dit asesor, e lo dit procurador, qui anava primer, vehent lo escàndol, manà al dit batle que lexàs anar lo dit asesor en aquell loch on era, e los cònsols, qui anaven a la altra part, digueren al dit procurador que, pus ell volia que axí:s fes, que els ni lo dit batle no $\mathrm{y}$ irien, e manaren a lurs verguers que tornassen atràs, e los dits cònsols e batle, e molts dels pròmens, se tornaren a sseure, que no anaren a la dita processó. E lo dit procurador, vehent lo escàndol quị s'era seguit, al daprés dinar levà lo bastó al dit batle e 1 feu metre a la presó. E, aprés, a supplicació dels dits consols, lo fon traure de la presó e-1 fon arrestar en casa sua» (ibídem, ff. 16v-17r). Al igual que en la anterior nota, transcribimos aquí, por su mayor concreción y claridad expositiva, los fragmentos que, sobre dicho conflicto, aparecen en las deliberaciones del consistorio barcelonés, si bien las cartas originales del obispo de Vic -para el caso anterior- y, muy especialmente, la del procurador del Condado d'Empúries, ofrecen una más detallada y pormenorizada descripción de los hechos.

${ }^{13}$ No iremos más allá en el desenlace y resolución de ambos conflictos, puesto que no es ese el motivo por el cual los hemos traído aquí a colación. Señalemos, en cualquier caso, que, el 10 de febrero de 1451, los consellers se dirigían al procurador del Condado de Empúries, felicitándole por su actuación y notifiçando la pronta intervención del consistorio barcelonés, una vez conocidos todos los detalles de la investigación que ya se estaba llevando a cabo (AHCB, CC, Lletres closes, VI-16, f. 12r). Por lo que respecta a Tàrrega, a finales de ese mismo mes sus puertas seguían cerradas: en carta fechada el 25 de febrero de 1451, los consellers de Barcelona insistían ante las autoridades de la villa, exigiendo la apertura de los portales de la misma y el pago de las cantidades debidas a los acreedores del erario municipal: «sabut havem com vosaltres denegats paga als creadors censalistas d'aqueixa vila de Tàrrega e, per aquesta causa, tenits tenquats los portals de la dita vila, qui és cosa perjuciosa e de fort mal eximpli, e qui mereix punició» (ibidem, f. 20r).

${ }^{14}$ Véase, para una reflexión de carácter general sobre algunos de estos aspectos, Jean-Pierre GUILHEMBET, Entrer en ville: interrogations et perspectives, en Françoise MICHAUD-FRÉJAVILLE;
} Noëlle DAUPHIN; Jean-Pierre GUILHEMBET (dirs.), Entrer en ville, Rennes, 2006, pp. 11-33. 
excluye y discrimina -en la misma medida que reconoce, acepta y distingue-, puede llegar, en determinadas circunstancias, a transformarse en verdadera medida de fuerza: la ciudad se hermetiza ante el peligro de la llegada del enemigo, pero también para impedir la presencia del señor no deseado ${ }^{15}$, o para evitar la traición del desafecto ${ }^{16}$.

Por su parte, el agitado desencuentro entre autoridades acaecido en Castelló d'Empúries, con motivo de la colocación de personalidades en una comitiva procesional, no era más que la enésima escenificación de una misma y perpetua realidad. En la ciudad bajomedieval -pero cómo asegurar que ello no sucede en todas las épocas-, procesiones, exequias fúnebres, desfiles y ceremonias de recepción aparecen siempre sometidos a un estricto protocolo, mediante el cual son capaces de reflejar el orden social que las envuelve. Todo acto público o evento institucional, cualquier ocasión en la que el cuerpo social urbano, o parte de él, se somete a representación, exige una impecable adecuación entre su puesta en escena y aquello que es susceptible de simbolizar. Aún más, el objetivo último de todas estas manifestaciones colectivas, por encima del acto puntual que las convoca, parece apuntar a la reconstrucción, ideal y armónica, de una jerarquizada estructura social. Es precisamente esa necesidad de conjugar cohesión y estratificación la que da pie a que toda ceremonia urbana sea una potencial oportunidad para evidenciar la fricción entre ambas.

Dentro de ese contexto, el lugar ocupado por los participantes en dichas ceremonias pretenderá ser la exacta representación de su estatus social y, por ello, toda modificación en lo primero podrá ser entendida como un

\footnotetext{
${ }^{15}$ En 1368, las autoridades de Castellón, en su negativa a quedar bajo dominio del infante Juan -a quien su padre, el rey Pedro el Ceremonioso, habia cedido la ciudad-, habían ordenado cerrar, uno tras otro, todọs los portales de la misma, para así impedir la entrada del nuevo señor. Según refería el propio infante, en carta dirigida a su progenitor, los habitantes de Castellón habían llegado a arrojarle piedras desde lo alto de las murallas para hacerle desistir de su intento de tomar posesión de la localidad (ACA, C, reg. 1735, f. 7V. La carta del infante Juan, donde se describe la impactante anécdota, ya ha sido transcrita por Daniel GIRONA I LLAGOSTERA, Itinerari de l'Infant En Joan, fill del rei Én Pere III, en III Congreso de Historia de la Corona de Aragón. 2 vols., Valencia, 1923, vol. II, p. 304). Igualmente, en 1461, la reina María, esposa de Juan IÎ -en aquel momento ya en pleno proceso de confrontación con las instituciones del Principado, a raíz de la detención del principe de Viana-, había visto como, tras ser rechazada por Barcelona, era posteriormente la villa de Terrasșa la que no sólo le négaba también la entrada, sino que incluso amenazaba con recurrir a la violencia si ésta persistía en su intento de alojarse en dicha localidad (Josep Maria SANS I TRAVÉ (ed.), Dietari o Llibre de Jornades (1411-1484) de Jaume Safont, Barcelona, 1992, p. 134). Ejemplos similares de puertas cerradas frente a la llegada del monarca han sido registrados, para el reino de Castilla, por A. I. CARRASCO, Símbolos y ritos. el conflicto como representación, pp. 539-544. Véanse también, en un contexto europeo, los ejemplos recogidos por Michel POPULER, Les entrées inaugurales des princes dans les villes. Usage et signification. L'exemple des trois comtés de Hainaut, Hollande et Zélande entre 1417 et 1433, "Revue du Nord", 304 (1994), pp. 25-52

${ }^{16} \mathrm{En} 1462$, tal como se preocupaba de precisar Jaume Safont en su dietario, Barcelona había cerrado, a cal y canto la mayoría de sus portales, no tan sólo para defenderse del asedio exterior de las tropas đ̣e Juan II, sino tạmbién para prevenir cualquier accción contraproducente planeada desde el interior de la propia ciudad: «e foren peradats los demés portals de la ciutat a pedra e a morter, no pas per por dels enemichs qui eren defora, mas per por de molts traÿdors que havia dins la present ciutat»(J.M. SANS (ed.), Dietari o Llibre de Jornades, p. 170).
} 
atentado a lo segundo ${ }^{17}$. La minuciosidad y la vehemencia con la que -a raíz de cualquier divergencia al respecto, como es el caso del comentado ejemplo de Castelló d'Empúries- se reacciona ante cualquier anomalía en el orden de precedencia considerado como establecido es una clara muestra de la importancia atribuida al poder de la escenificación ${ }^{18}$. Autoridades municipales, oficiales reales, instituciones supralocales, dignidades eclesiásticas, estamentos ciudadanos, comunidades religiosas, son protagonistas, en uno u otro momento, de este tipo de episodios. En ellos, tradición y presente, memoria y reivindicación, prerrogativas y aspiraciones compiten como expresión del consustancial juego de fuerzas que afecta, en todos sus niveles, al conjunto de la sociedad urbana bajomedieval.

Así, en 1431, con motivo de las exequias de la reina Violante, viuda del rey Juan I, en Barcelona, serán los conventos femeninos de Valldonzella y de Jonqueres los que esgriman sus eternas diferencias acerca del orden a ocupar en todo acto solemne ${ }^{19}$. En 1436, sin embargo, durante los funerales por la muerte de la reina Leonor, viuda del rey Fernando I, serán los propios consellers barceloneses los que se enfrenten a los diputados de la Generalitat a causa de la colocación de algunos oficiales de esta última institución en la comitiva procesional $^{20}$. Y en 1479 , en los actos organizados tras la muerte del rey Juan II, serán los miembros de la corte real quienes mantengan un enconado pulso con los ediles municipales de Barcelona acerca de la disposición general del séquito fúnebre ${ }^{21}$.

\footnotetext{
${ }^{17}$ Puede encontrarse una argumentación similar en Wim BLOCKMANS; Esther DONCKERS, SelfRepresentation of Court and City in Flanders and Brabant in the Fifteenth and Early Sixteenth Centuries, en Wim BloCKMANS; Antheun JANSE (eds.), Showing Status. Representation of Social Positions in the Late Middle Ages, Turnhout, Brepols, 1999, pp. 91-92.

${ }^{18}$ No entraremos aquí en la ya conocida discusión acerca de la capacidad performativa de los rituales y sus ceremonias. Señalemos, en todo caso, que si, para Richard Trexler, el ritual no sólo expresa, sino que crea el orden político, para Elodie Lecuppre-Desjardin, por el contrario, la ceremonia se limita a acompañar dicho orden político. Peter Arnadẹ, por su parte, sostiene que lo simbólico no es algo externo a la realidad, sino parte de esa misma realidad, mientras que Georges Balandier, a la hora de referirse a la sociedad medieval, no duda en calificarla de "teatralizada". Véanse, para estas diferentes apreciaciones del tema, R. TREXLER, Public Life in Renaissance Florence; E. LECUPPRE-DESJARDIN, La ville des cérémonies; P. ARNADE, Realms of Ritual; Georges BALANDIER, Le pouvoir sur scènes, Paris, 1980. Igualmente, es obligado citar aquí al antropólogo Clifford GEERTZ, el gran activador de todo este debate, y su obra, ya clásica, Negara: The Theatre State in 19th Century Bali, Princeton, 1980.

${ }^{19}$ De hecho, ni uno ni otro participaron en dicho funeral, puesto que, para evitar todo conflicto -y dado que ambos monasterios ya se habían significado negativamente en ese sentido durante las exequias de la reina Sibila, esposa de Martín el Humano, en 1406-, las autoridades barcelonesas, de acuerdo con el canciller real, habían prohibido, de manera indefinida, su presencia en toda solemnidad fúnebre celebrada en la ciudad. Véase Llibre de les Solemnitats de Barcelona, vol. I, pp. 50-51.

${ }^{20}$ Finalmente, los diputados de la Generalitat -o Diputación del General, institución que actuaba como delegación permanente de las Cortes catalanas, y que tenía su residencia oficial en Barcelona-, en muestra de desacuerdo, habían abandonado la comitiva y se habían desplazado por su cuenta hasta la Catedral (ibídem, pp. 69-70).

${ }^{21}$ Tras sendas consultas en los registros del archivo real y del municipal, se pudo comprobar que era a las autoridades barcelonesas a las que, por tradición, competía el ordenamiento protocolario de personalidades durante las exequias reales celebradas en la ciudad (ibídem, $\mathrm{p}$ 306). Puede encontrarse una breve aproximación a este conflicto en Flocel SABATÉ, Lo senyor rei és mort!, Lleida, 1994, p. 186.
} 
Por su parte, ciudadanos honrados, mercaderes y artesanos aparecen igualmente inmersos en esta misma dinámica. En 1425, el estamento mercader barcelonés se negará a desfilar en la hueste municipal si no es junto a los ciudadanos honrados y bajo un mismo pendón identificativo, en un intento por salvar escénicamente la distancia que los separa de los miembros de la elite urbana $^{22}$. Y en 1433, coincidiendo con la celebración anual del Corpus, un destacado grupo de mercaderes barceloneses se desmarcará provocativamente de las procesiones y desfiles cívicos que acompañan dicha festividad, en señal de protesta ante el lugar ocupado por su máximo representante -uno de los dos cònsols de mar de la ciudad- en dichos actos públicos ${ }^{23}$.

Es precisamente la procesión general del Corpus -junto a las entradas reales- uno de los momentos básicos para la escenificación de la estructura artesanal urbana. La importancia de la ordenación protocolaria de los distintos oficios en estos desfiles -en tanto que expresión de la jerarquización interna de dicho estamento- genera una notable tensión entre sus componentes y es causa de continuas diferencias e incidentes que necesitan de la intermediación de las autoridades municipales para poder ser resueltos. En 1520, los consellers de Barcelona, para poner fin a la repetida disputa que, en torno al tema de la precedencia ceremonial en la procesión del Corpus, se desataba cada año entre los oficios artesanales de la ciudad, se vieron obligados a fijar, con minucioso detalle, el lugar exacto que cada uno de ellos debía ocupar en dicha celebración ${ }^{24}$.

Obviamente -como ya hemos apuntado anteriormente-, este tipo de situaciones conflictivas, a pesar de poseer sentido por sí mismas, son además capaces de contener $-\mathrm{y}$, en cierta medida, esconder y disfrazar- todo tipo de

\footnotetext{
${ }^{22}$ Mediante ordenanza pública, las autoridades de Barcelona acabaron determinando que los mercaderes debían concurrir a la hueste de la ciudad bajo su propio pendón, tal como así había venido sucediendo desde siempre. Para este episodio, véase Carmen BATLLE, La crisis social y económica de Barcelona a mediados del siglo XV, 2 vols., Barcelona, 1973, vol. I, pp. 137-138.

${ }^{23} \mathrm{El}$ grupo de mercaderes, encabezado por el propio cònsol de mar, se había exhibido por las calles de Barcelona a lomos de sus monturas, paralelamente a los actos presididos por los consellers. El gesto, finalmente, comportó importantes represalias de orden político y económico sobre los mercaderes participantes en dicha discrepancia ceremonial. El altercado ha quedado registrado con detalle en la documentación municipal de la época (AHCB, CC, Deliberacions. II-1, ff. 16v-25r), habiendo ya sido abordado, en su momento, por C. BATLLE, La crisis social y económica de Barcelona, pp. 138-140.

${ }^{24}$ «per cessar tota natura de disordres y diferències que entre los dits officis e confreries se porien seguiir per causa de les precedències o graduaments de aquells, segons que en lo passat és stat vist, si present no y era» (AHCB, CC, Ordinacions, IV-12, ff. 179r). Para una reflexión sobre el estamento artesanal barcelonés, en relación a su participación en las ceremonias cívicas de la ciudad, véase M. RAUFAST, "E vingueren los officis e confraries ab llurs entremeses e balls". Igualmente, para otros casos comparables de conflictividad ceremonial en el mundo artesanal de la Europa medieval, véanse, a título de ejemplo, P. ARNADE, Realms of Ritual, pp. 55-56; Maria Isabel FALCÓN PÉREZ, Las cofradías artesanales de la Edad Media. Aspectos religiosos y sociales, en Maria BARCELO CRESPÍ (ed.), La manufactura urbana $i$ els menestrals (SS. XIII-XVI) (IX Jornades d'Estudis Històrics Locals, Palma, 1990), Palma, 1991, p. 210 Rodrigo J. FERRER FORTUNY, Mundo urbano y discurso procesional en la Valencia bajomedieval, en Isabel Moll BLANES (ed.), La vida quotidiana en la Valencia bajomedieval (III Jornades d'Estudis Historics Locals, Palma, 1983), Palma, 1985, pp. 182-183; Alexandra F. JOHNSTON, The Guild of Corpus Christi and the Procession of Corpus Christi in York, "Medieval Studies", 38 (1976), p. 382, Katharina SIMON-MUSCHEID, Les documents normatifs et les «vécus» d'après les inventaires. Les cas de Bâle et de la région du Haut-Rhin, en Pascale LAMBRECHTS; JeanPierre Sosson (eds.), Les métiers au Moyen Age. Aspects économiques et sociaux, Louvain-laNeuve, Université Catholique de Louvain, 1994, p. 321.
} 
discordancias ajenas a lo escénico que encuentran en el evento ceremonial una clara oportunidad para emerger a la superficie. En consecuencia, la lectura de estos episodios se enriquece y complica al mismo tiempo. Siguiendo esta idea, podríamos plantearnos hasta qué punto el altercado acaecido en la iglesia de Castelló d'Empúries, con el cual abríamos este apartado, no era tan sólo una visible confrontación en torno al poder de la escenificación, sino también la posible expresión ocasional de tensiones de índole política y económica entre los que tomaban parte en él ${ }^{25}$. Tensiones que, como hemos podido comprobar en el caso de las puertas cerradas de Tàrrega -el otro ejemplo descrito en el inicio del apartado-, podían llevar a prescindir de todo protocolo y, calculadamente, transformar la iniciativa ceremonial en una contundente declaración de intenciones.

De todos estos aspectos -y es por ello que les hemos dedicado nuestra atención- participa la ceremonia de entrada real en la Barcelona bajomedieval. Su materialización precisa de múltiples negociaciones, dado que en ella confluyen, por un lado, la escenificación, en su forma más solemne, de la relación ciudad-visitante, y, por otro, la visualización de la estructura sociopolítica de la urbe. Los preámbulos rituales que demoran el momento del ingreso del monarca en el recinto amurallado ${ }^{26}$; la trascendencia que rodea el instante en el que éste realiza el juramento por el cual se compromete a respetar las libertades y privilegios de la $\operatorname{ciudad}^{27}$; la importancia de la designación de aquellas personalidades que acompañarán al visitante a lo largo de su ceremonial desplazamiento por las calles de Barcelona ${ }^{28}$; la necesaria participación de los oficios artesanales en el festivo, pero ordenado, desfile

\footnotetext{
${ }^{25}$ Por ejemplo, las derivadas del habitual control que desde Barcelona, en aras a garantizar el aprovisionamiento de la misma, se efectuaba sobre la comercialización de la producción cerealística del Condado d'Empúries. En el mismo mes de febrero de 1451 en el cual se había producido el conflicto ceremonial entre los representantes institucionales de ambas localidades, los consellers barceloneses apremiaban a su procurador para que evitara la salida incontrolada de cereal desde el Condado hacia otros destinos que no fueran la propia ciudad de Barcelona. Ambos asuntos -el conflicto ceremonial y el cerealístico - llegaron a aparecer reunidos, por esas fechas, en una misma carta enviada por los consellers a dicho procurador (AHCB, CC, Lletres closes, VI-16, f. 12r. 1451, febrero, 10. Barcelona). Acerca de la relación económica entre Barcelona y el Condado d'Empúries, véase E. RIERA, Etapa barcelonesa del Condado de Ampurias.

${ }^{26}$ La tradición imponía que el ilustre visitante fuera recibido, a una cierta distancia de los muros de la ciudad, por parte de las autoridades municipales, acompañadas de una selecta representación de los distintos estamentos urbanos, en una ceremonia perfectamente graduada que excluía toda iniciativa individual. Esa misma tradición disponía que el monarca, en su primera visita como tal, había de alojarse, como mínimo una noche, en las inmediaciones de la ciudad antes de poder penetrar en ella. Para una visión desglosada de las fases que componían la ceremonia de entrada real en la Barcelona bajomedieval, remitimos, a partir de ahora, a L. KOVACS, La ciutat com a escenari; M. RAUFAST, Imágenes para una ceremonia.

${ }^{27}$ Dicho juramento -que, en Barcelona, el nuevo rey realizaba ya en el interior del recinto urbano, instalado en un catafalco honorífico- establecía las bases fundamentales de la relación contractual con el municipio y, por tanto, era objeto de meticulosas observaciones. En 1458, en su entrada en la ciudad de Lleida, Juan II se había negado a realizar el juramento que le presentaba la ciudad, al detectar que no seguía exactamente al pie de la letra el texto de los que habían efectuado sus antecesores en el trono (AML1, Cerimonial Antich, reg. 700, f. 47r).

${ }^{28}$ Ya fuera sosteniendo las varas del palio que cubría y ensalzaba la figura del visitante, sujetando las riendas de su montura, o bien llevando los cordones ceremoniales que servían para conducir al ilustre jinete a través de la ciudad. Consellers, altos cargos municipales y personalidades de los diferentes estamentos barceloneses acaparaban tradicionalmente la mayor parte de estas designaciones.
} 
con el que se honra la presencia del soberano ${ }^{29}$; el donativo que la ciudad concederá graciosamente al rey con motivo de dicha primera visita ${ }^{30}$; e incluso la celebración de las justas urbanas que han de añadir espectacularidad al evento $^{31}$, son potenciales fuentes de discordia, a las cuales habría que sumar la propia capacidad de la ceremonia, en su conjunto, para convertirse en conflicto.

Conflictos, por tanto, internos -siempre desde un punto de vista urbano-, puesto que se nutren de los desajustes entre la imagen armónica que la ciudad pretende ofrecer de sí misma en toda entrada real y la realidad tensionada de su estructura social ${ }^{32}$, pero también externos, dado que la ceremonia nace del encuentro entre los intereses - no necesariamente coincidentes, en ocasiones incluso antagónicos- de dos universos distintos -el municipio y la monarquía-, poseedores de ritualidad escénica propia, creadores ambos de simbología política y, por tanto, capaces de interpretar en términos diferentes el sentido de un mismo gesto, de una misma celebración ${ }^{33}$.

En definitiva, es dentro de este contexto básico de eventuales fricciones, de latente -cuando no explícita- conflictividad, donde se desarrolla toda entrada real. La propia dimensión del evento y su trascendencia política confieren mayor relevancia, si cabe, a cualquier anomalía en su puesta en escena $^{34}$, pero, aún así, mantiene una clara proximidad con lo que ya ha sido expuesto en este apartado. Portales cerrados, ceremonias convulsas, divergencias institucionales, desacuerdos protocolarios, la entrada del rey contiene, en sí misma, el conflicto; es capaz de reflejar tensiones -económicas, sociales, políticas- ajenas a ella; y, en último extremo, por encima de

\footnotetext{
${ }^{29}$ Desfile que, como ya hemos indicado anteriormente, estaba sujeto a todo tipo de tensiones internas en relación al orden ocupado en él por las distintas agrupaciones artesanales.

${ }^{30}$ Heredera de una tradición claramente relacionada con las prácticas del mundo feudal, la concesión del donativo distinguía la autoridad del visitante, y únicamente reyes, reinas y primogénitos tenían derecho a él. Una lujosa vajilla de plata -de mayor valor en el caso del soberano- era la forma adoptada por dicho donativo en la Barcelona bajomedieval.

${ }^{31}$ Por norma general, eran los miembros de la elite urbana barcelonesa -los ciutadans honratslos que se señalaban en esta práctica de raigambre caballeresca tradicionalmente asociada a la nobleza. En 1458, un desacuerdo entre los consellers de Barcelona acerca de los elegidos para participar en las justas organizadas con motivo de la entrada real de Juan II, había desembocado en un cruce de acusaciones en el que se había llegado a cuestionar la fidelidad al rey de uno de los discrepantes: «som forsats creura vós, e tots aquells que tals actes fan e ginyen, no trobar pler en la successió del dit senyor rey, e menys en sa beneventurada entrada» (AHCB, Manuscrits L, Ceremonial, 1.M.I.1, s. f.).

${ }^{32}$ Véase, para un particular ejemplo de esta cuestión, Jean TRICARD, Le consul, le moine et le roi: entrées royales et antagonismes urbains à Limoges au $X V^{e}$ siècle en Patrick BOUCHERON; Jacques CHIFFOLEAU (comps.), Religion et société urbaine au Moyen Age, París, 2000, pp. 403412 .

${ }^{33}$ Una cirçunstancia que, en cierta medida, queda reflejada en lọ variados calificativos que han sido esgrimidos por los historiadores a la hora de intentar definir la entrada real (ceremonia de inauguración, contrato social, triunfo político, acto de sumisión, etc.), y que muestran esa doble lectura de la ceremonia, según se quiera destacar el papel dẹsempenado en ella por la monarquía o por las instituciones urbanas. Para un intento de reflexión sobre esta cuestion, en relación a la Barcelona bajomedieval, véanse M. RAUFAST, ¿Negociar la entrada del rey?; IDEM, ¿Una misma ceremonia para dos dinastías?

${ }^{34}$ La anécdota pertenece a Eḍward Muir: en 1484, trạs la entrada de Carlos VIII en París, la totalidad del Parlamento de la ciudad fue sometida a juicio por parte del tribunal real, al haberse detectado cambios injustificados en el regulado orden de colocación de aquellos que habían recibido al monarca a su llegada (E. MUIR, Fiesta y rito en la Europa Moderna, p. 298).
} 
todo protocolo, puede llegar a transformarse en una verdadera y concluyente declaración de intenciones.

\section{LA ENTRADA REAL COMO CONFLICTO (1460-1461)}

En 1458, Barcelona recibía, con una solemnidad casi olvidada, a Juan II, el nuevo monarca de la Corona de Aragón ${ }^{35}$. El tiempo transcurrido desde la última vez que la ciudad había celebrado una entrada real -más de cuarenta años-, había obligado a las autoridades municipales -y también al propio reya buscar en la memoria de los archivos -así como en la de las personas- para acomodar dicho evento a las pautas ya difuminadas de la tradición ${ }^{36}$. Finalmente, la pista había sido encontrada y, tras las pertinentes deliberaciones, el consistorio barcelonés había decidido que la entrada de Juan II siguiese, paso a paso, el modelo de la recepción solemne que la ciudad había ofrecido a su padre, Fernando I, en $1412^{37}$.

De acuerdo a dicha disposición, y con el beneplácito del propio Juan II, el 21 de noviembre de 1458 el nuevo soberano había sido recibido institucionalmente por los representantes de la ciudad a una cierta distancia de la misma y, esa misma noche, se había alojado en el cercano monasterio de Valldonzella, a la espera de poder efectuar su entrada en Barcelona un día después. El 22 de noviembre, atravesando el Portal de les Drassanes -así llamado por su proximidad a las atarazanas de la ciudad (véase figura anexa ${ }^{38}$ )-, el rey había accedido al interior del recinto amurallado y, desde un catafalco honorífico instalado en la plaza de Framenors -junto al convento de

\footnotetext{
${ }^{35}$ Segundo hijo de Fernando I y hermano de Alfonso el Magnánimo, Juan II ya era, desde 1425, rey de Navarra, gracias a su matrimonio con Blanca, hija de Carlos III el Noble. En su compleja $\mathrm{y}$, muy a menudo, tormentosa trayectoria política destacaba también, hasta ese momento, su enconada oposición a la rama trastámara reinante en Castilla y sus reiteradas $-\mathrm{y}$ agitadas- intervenciones en la política de dicho reino. Acerca de la figura de este monarca, veanse, entre otros, J. VICENS VIVES, Juan II de Aragón; IDEM, Els afers castellans de Joan II de Catalunya-Aragó, "Butlletí de la Societat Catalana d'Estudis Histọrics", I (1952), pp. 17-24; Amancio FERNÁNDEZ TORREGROSA, Aspectos de la política exterior de Juan II de Aragón, "Estudios de Historia Moderna", II (1952), pp. 99-132; Jose María de FRANCISCo OLMOS, Juan II de Aragón y el nacimiento del príncipe Juan. Consejos políticos a Fernando el Católico, "En la España Medieval", 18 (1995), pp. 241-256; M ${ }^{\mathrm{a}}$ Isabel OSTOLAZA, D. Juan de Aragón y Navarra, un verdadero príncipe Trastámara, "Aragón en la Edad Media", XVI (2000), pp. 591610; Julio VALDEÓN, Los trastámaras. El triunfo de una dinastía bastarda, Madrid, 2001, pp. 233-259.

${ }^{36}$ Para todo lo referente al largo proceso de preparación que precẹdió a la entrada de Juan II en Barcelona, así como sobre los detalles de su materialización, remitimos, a partir de ahora, a M. RAUFAST, ¿Negociar la entrada del rey?. Puede encontrarse, igualmente, una aproximación a la relación de dicha entrada con la tradición celebrativa de este tipo de ceremonias en la Barcelona bajomedieval en IDEM, ¿Una misma ceremonia para dos dinastías?.

${ }^{37}$ Como ya hemos comentado en el inicio de este artículo, la entrada real de Alfonso el Magnánimo en Barcelona, en 1416, había carecido -debido a la muerte todavía reciente de Fernando I- del brillo y la solemnidad habituales, y, por ello, no aparecía como un modelo válido a seguir en esta oportunidad.

${ }^{38}$ Figura a la cual remitimos, a partir de ahora, para la ubicación exacta de los elementos de carácter urbanístico (calles, plazas, portales, edificios) que irán apareciendo a lo largo de este artículo.
} 
Sant Francesc-, había jurado respetar los privilegios de la ciudad. Dicho gesto había activado el inicio de la exhibición de los oficios artesanales, cuyos miembros habían desfilado ante el monarca acompañados de bailes y representaciones, y, luego, el monarca los había seguido en su trayecto solemne hacia el centro del núcleo urbano. Bajo palio, rodeado por los dirigentes municipales, guiada su montura por escogidos ciudadanos de todos los estamentos, Juan II había recorrido las principales calles de Barcelona, engalanadas para la ocasión, y, en las inmediaciones de la Catedral, había sido acogido en procesión por el clero para ser conducido, a continuación, al interior del templo. Por último, acabada la liturgia religiosa, el rey se había dirigido, flanqueado de nuevo por los regidores barceloneses, al Palacio Episcopal, donde había de alojarse durante su estancia en la ciudad. Justas urbanas, hogueras celebrativas y algarabías populares habían añadido mayor vistosidad a un evento que, a manera de colofón, comportaba la concesión, por parte del municipio, de un costoso donativo en forma de vajilla de plata. Del mismo modo, un día más tarde, la ciudad había repetido una ceremonia prácticamente idéntica en honor de la reina Juana, esposa del monarca.

La fidelidad a la tradición por parte del consistorio barcelonés no era, en todo caso, un pretendido homenaje a las prácticas de la ciudad en el pasado, sino un recurso indispensable para garantizar, inicialmente, la salvaguarda de los intereses de la misma. Así, al igual que Juan II se preocupaba por conocer los detalles de las entradas que sus predecesores en el trono habían realizado en Barcelona -en una minuciosa pesquisa que, sospechamos, tenía como objetivo evitar cualquier tipo de merma en su dignidad real-, los dirigentes municipales también recurrían a un similar - pero aún más preciso- ejercicio de memoria para prevenir que nada, durante la nueva ceremonia, pudiese ir en detrimento del prestigio y honor adquiridos por la ciudad a lo largo de los años.

Y, sin embargo, apenas recuperada la tradición, ésta comenzó a diluirse en las aguas de un presente torrencial. El conflicto entre Juan II y el príncipe de Viana, primero, y la Guerra Civil Catalana, después, determinaron que ya nada fuera igual a partir de 1460 . En realidad, hasta 1479, con la primera visita de Fernando II como sucesor del fallecido Juan II, Barcelona no volvería a experimentar una relativa sensación de normalidad en este tipo de ceremonias. Entre esos años, pero básicamente en el período comprendido entre 1460 y 1473 , las recepciones ofrecidas por la ciudad a la monarquía estuvieron siempre marcadas por la urgencia del momento. Es, precisamente, ese rasgo de inmediatez el que confiere una dimensión histórica añadida a las entradas reales que, desde este instante, serán objeto de nuestra atención.

\section{1460}

¿Cómo recibir a aquel que se autopresentaba como "primogénito de Aragón y de Sicilia", a pesar de que, sin embargo, nunca había sido reconocido oficialmente como tal por su progenitor, el rey? ¿Qué ceremonia organizar para contentar a uno, sin desautorizar al otro? A finales de marzo 
de 1460, la llegada del príncipe de Viana a Barcelona obligó a los regidores municipales a enfrentarse a esa disyuntiva. Al desembarcar en la playa de la ciudad, procedente de Mallorca, Carlos de Viana traía consigo el permanente conflicto que lo enfrentaba desde hacía años con su padre, Juan II, y lo depositaba a las puertas de la misma Barcelona ${ }^{39}$. Instalado en el monasterio de Valldonzella -el mismo en el que el rey se había alojado antes de su entrada en 1458-, el príncipe se entrevistaba discretamente en la noche del 28 de marzo con los delegados enviados por la ciudad y, tres días después, en la tarde del 31 de marzo, entraba en ella con la solemnidad atribuible a un primogénito y de manera muy similar a como lo había hecho su padre dos años antes ${ }^{40}$. Así había sido decidido por el consistorio barcelonés, en la mañana del 29 de marzo, tras la consulta de los registros escritos de anteriores recepciones ofrecidas, en el pasado, por el municipio, tanto a hijos de reyes como a primogénitos. Con dicha resolución, en la cual la tradición ceremonial parecía convivir con la apuesta política, Barcelona $-\mathrm{y}$, con ella, el resto del Principado- acababa asumiendo como propio un conflicto que, hasta ese momento, siempre había contemplado desde una prudente distancia ${ }^{41}$.

Pocos días después de la celebración, la ciudad quedaba enredada para siempre en la compleja, ambigua y diplomáticamente enrevesada disputa paterno-filial. A ojos de Juan II -tal como el propio soberano exponía por carta, desde Navarra, a los consellers-, resultaba inaceptable que Barcelona hubiese concedido trato de primogénito a quien aún no lo era, y prohibía taxativamente que, en adelante y sin su permiso, ello volviese a producirse en cualquier punto del Principado. En otras palabras -retomando los conceptos

${ }^{39}$ Las diferencias irreconciliables entre padre e hijo se remontaban hasta 1441 , cuando, tras la muerte de la reina Blanca, ambos -en tanto que esposo y primogénito, respectivamente, de la armada se habían ido alternando con frágiles concordias e inestables fases de tregua hasta que, finalmente, desposeído de todo derecho a al trono, el príncipe de Viana se había visto obligado a abandonar Navarra en 1456. En su periplo europeo, Carlos había visitado la corte de su tío, Alfonso el Magnánimo, en Nápoles, para instalarse, a continuación, en 1458, en Sicilia. Finalmente, fruto de un nuevo intento de acercamiento diplomático con Juan II, ahora ya rey de la Corona de Aragón y de Navarra, el príncipe había llegado, en agosto de 1459, a la isla de Mallorca, a la espera de poder regresar, de nuevo, a la Península. La concordia firmada entre padre e hijo a inicios de 1460, aunque posibilitaba dicho retorno, mantenía, sin embargo, la prọibición de visitar el reino de Navarra y no se pronunciaba en ningún sentiḍo acerca de la primogenitura oficial reclamada por el príncipe, un reconocimiento que le hubiese convertido automaticamente en el futuro sucesor de Juan II en el trono de la Corona de Aragón. Acerca de todo lo relacionado con este largo conflicto, véanse George DESDEVISES DU DEZERT, Don Carlos de Aragón, Príncipe de Viana, Pamplona, 1999 (Edición original en París, 1889); J. VICENS VIVES, Juan II de Aragón; IDEM, Trajectòria mediterrània del Príncep de Viana, Barcelona, 1961; Eloisa RAMÍREZ VAQUERo, Blanca, Juan II y el Príncipe de Viana, Pamplona, 1986.

${ }^{40} \mathrm{Al}$ igual que Juan II, el príncipe de Viana había contemplado, desde un catafalco construido en la plaza de Framenors, el desfile de los oficios de la ciudad, había recorrido bajo palio las calles de la ciudad, y había sido recibido por el clero en procesión antes de visitar la Catedral. Puede encontrarse una descripción coetánea de dicha ceremonia en Manual de Novells Ardits, vulgarment apellat Dietari del Antich Consell Barceloní, 28 vols., Barcelona, 1892-1992, vol. II, pp. 332 .

${ }^{41}$ En un trabajo anterior, ya hemos intentado ofrecer una lectura política de la recepción ofrecida por Barcelona al príncipe de Viana en marzo de 1460 , relacionando, además, dicha entrada con la actividad que, como intermediadora en el conflicto entre padre e hijo, había venido desplegando la ciudad hasta entonces. Por tanto, para todos los detalles acerca de esta ceremonia y de su interpretación, remitimos, a partir de ahora, a Miguel RAUFAST CHICO, ¿Recibir al primogénito?. 
expuestos en el apartado anterior-, para el monarca, Carlos de Viana no solamente había ocupado un lugar que no era exactamente el suyo en la ceremonia de entrada en Barcelona, sino que, de hecho, toda la puesta en escena de la misma desvirtuaba la realidad de las cosas, reconstruyendo y legitimando un orden dinástico que no existía y que, además, podía ser entendido como una amenaza contra los intereses y el estatus del soberano.

La importancia y trascendencia atribuida a lo escénico quedó nuevamente de manifiesto apenas un mes y medio más tarde, cuando, a mediados de mayo de 1460, Barcelona recibió al conjunto de la familia real. Tras un encuentro previo en Igualada entre los reyes, que regresaban desde Aragón, y el príncipe de Viana, en lo que era el primer paso de una aparente reconciliación final, el grupo había efectuado su entrada en Barcelona con un orden intencionadamente preciso, mediante el cual se pretendía recomponer visualmente la posible fractura creada por la anterior recepción ofrecida al príncipe. Así, sin mayor solemnidad de la que, según el código ceremonial de la ciudad, correspondía a la ocasión ${ }^{42}$, Juan II había sido recibido institucionalmente en el exterior de las murallas para, a continuación, ser acompañado directamente hasta su alojamiento en el interior de un recinto urbano iluminado con profusión por tal motivo. Tras él, la reina y Carlos de Viana -quienes precedían, a su vez, al resto del séquito real- habían sido acogidos con idéntica atención. De esta forma, cabalgando entre el rey, su madrastra y sus hermanastros, el príncipe aparecía teatralmente integrado en un esquema de representación dinástico que, prescindiendo de cualquier referencia al tema de la primogenitura, aspiraba a eliminar toda confusión al respecto ${ }^{43}$.

A pesar de todo ello, el armonioso intento de puesta en escena no fue, en realidad, más que la fugaz antesala de un estallido retardado en el que acabaron detonando no una, sino dos vías de extrema conflictividad. En diciembre de 1460, mientras el consistorio barcelonés seguía embarcado en un tan enconado como infructuoso e inacabable debate acerca de la elección

${ }^{42}$ La tradición ceremonial de la Barcelona bajomedieval determinaba que la máxima solemnidad en la celebración de una entrada tan sólo podía ser dispensada al rey, la reina y el primogénito al trono en su primera visita a la ciudad, mientras que el resto de la familia real tenía derecho a recepciones mucho más modestas, al igual que los miembros de otras dinastías extranjeras. En sus posteriores llegadas a Barcelona, tanto el rey como la reina y el primogénito no podían reclamar una distinción equivalente a la de su primera entrada, si bien la ciudad -a manera de voluntaria concesión, nunca por establecida obligación- podia, en función de las circunstancias, acceder a ello. Para un intento de esbozo del código ceremonial imperante, con respecto a este tipo de eventos, en la Barcelona del siglo XV, véase M. RAUFAST, ¿Recibir al primogénito?.

${ }^{43}$ Acorde a esta intencionalidad, el dietario de la Generalitat identificaba, con un detallismo digno de mención, a los participantes en la entrada: «Aquest die entraren en Barchinona lo senyor rey, la senyora reyna, lo senyor don Karles, príncep de Viana, fill primer nat del dit senyor e de la reyna dona Blancha de Navarra, quòndam, primera muller sua, 1 infant don Fferrando, fill del dit senyor rey e de la senyora reyna huy benaventuradament regnant, don Johan, archabisbe de Ceragoça, e don Alonso, fills naturals del dit senyor rey; lo comte d'Empúries, nabot del dit senyor, e en companyia lur los bisbes de Gerona, d'Euna e de Vich, lo comte de Prades, mestra de Munteça, e molts altres barons, cavallers, gentils hòmens e altres familia lur» (Josep Maria SANS I TRAVÉ (dir.), Dietaris de la Generalitat de Catalunya, 10 vols., Barcelona, 1994, vol. I, p. 155). De hecho, en esas fechas, Juan II persistía en su negativa a permitir que el príncipe de Viana pudiese ser tratado como primogénito bajo ningún concepto. Para una primera aproximación a esta ceremonia y a las circunstancias que rodearon su desarrollo, vease $\mathbf{M}$. RAUFAST, ¿Recibir al primogénito?. 
de representantes para las Cortes convocadas por Juan II en Lleida -en lo que era una clara expresión de la división política que caracterizaba a la ciudad, escindida en los bandos rivales de la Biga y la $\mathrm{BusCa}^{44}$, el monarca procedía a detener, en la misma Lleida, al príncipe de Viana, acusado de tratar en secreto con el rey de Castilla ${ }^{45}$. A la larga, uno y otro conflicto, coexistiendo, enredándose, desembocarían, junto a otras circunstancias, en un mismo desenlace: la Guerra Civil Catalana iniciada en $1462^{46}$.

\section{1461}

Todo el proceso, primero diplomático, luego plenamente militarizado, puesto en marcha por parte del Principado, desde inicios de diciembre de 1460 hasta los primeros días de marzo de 1461, en aras a conseguir la liberación del príncipe de Viana, constituye un punto fundamental de inflexión en la relación de las instituciones catalanas con la monarquía, sin el cual resulta difícil entender la tremenda grieta que, posteriormente, se estableció entre ellas ${ }^{47}$. La creación del Consell del Principat -comisión de urgencia que integraba a representantes de los tres brazos parlamentarios catalanes-; la persistente y decidida actuación de las numerosas embajadas enviadas desde Cataluña ante Juan II -en representación tanto del propio Principado como de los principales núcleos urbanos del mismo, con la ciudad de Barcelona a la cabeza-; la

\footnotetext{
${ }^{44}$ En 1453, la intervención de Alfonso el Magnánimo había provocado que el gobierno municipal de Barcelona, tradicionalmente acaparado por la élite urbana -los ciutadans honratsque integraba el grupo de la Biga, pasara a manos del sector opositor que, compuesto principalmente por mercaderes y artesanos, respondía al nombre de la Busca. De la combinación entre las medidas reformistas impulsadas por los nuevos dirigentes y la resistencia de la oligarquía a perder el dominio político de la ciudad surgía un agitado escenario en el que los actores, en ocasiones, olvidaban el nuevo papel que les hábía sido asignado. En 1458, ante los altercados y malentendidos provocados por esa cuestión, el consistorio municipal había teniḍo que obligar a aquellos que habían desempeñado el cargo de conseller en el pasado a desistir de intentar participar en las ceremonias y actos públicos utilizando dicha pretérita atribución (AHCB, CC Deliberacions, II-11, ff. $21 \mathrm{r}-23 \mathrm{v}$. 1458, mayo, 12). Acerca de este agitado período en el gobierno de la Barcelona del siglo XV, remitimos al clásico estudio realizado por C. BATLLE, La crisis social y económica de Barcelona a mediados del siglo XV.

${ }^{45}$ Así recogía Jaume Safont, escribano de la Generalitat, dicha detención en su dietario: «Dimarts, a II de deembre MCCCCLX, III hores passades aprés del seny de l'Avemaria, lo senyor rey, essent en la ciutat de Leyda, a on celebrava corts als cathalans, apresonà son fill lo il·lustre don Karles, príncep de Viana, e lo noble don Johan de Beamunt, prior de Navarra, e Gome de Fris, de casa del dít príncep, per la qual presó tota aquella nit e lo sendemà, axí per los convocats per la cort, com encara per tots los pobles de Leyda tant hòmens com dones e infants, se moch gran dol e grans gemechs per tota aquella ciutat. E de aquesta presó se seguiren molts mals en Cathalunya» (J.M. SANS (ed.), Dietari o Llibre de Jornades, p. 124).

${ }^{46}$ La frase de Carme Batlle intenta resumir esta interrelación: «En ese preciso momento, tan grave, la agitada vida del príncipe de Viana interfirió como factor decisivo en la división interna de Barcelona y la anuló un instante para hacerla luego todavía más profunda» (C. BATLLE, $L a$ crisis social y económica de Barcelona a mediados del siglo $X V$, vol. I, p. 352).

${ }^{47}$ Un proceso que reclama urgentemente ser estudiado a fondo, no sólo por lo que tiene de impresionante ejemplo de puesta en escena de la práctica diplomática bajomedieval, sino debido también a las importantes formulaciones de carácter jurídico y político que en él llegaron a exponerse. Remitimos, en cualquier caso, para una aproximación a esta cuestión, a los trabajos, ya lejanos en el tiempo, de G. DESDEVISES, Don Carlos de Aragón, pp. 337-354, y J. VICENS VIVES, Juan II de Aragón, pp. 222-227, así como al mucho más reciente de Jaume SOBREQUÉS I CALLICÓ, El primer memorial de greuges del catalanisme polític: l'ambaixada de la Diputació del General $i$ del Consell del Principat a Joan II (1460-1461), "Butlletí de la Societat Catalana d'Estudis Històrics", XVI (2005), pp. 9-35.
} 
progresiva y finalmente radical transformación del discurso utilizado -las iniciales y respetuosas peticiones de favor al rey habían dado paso, ante la negativa de éste, a duros alegatos de carácter constitucional que incumbían, antes que a la puntual libertad del príncipe de Viana, a los irrenunciables privilegios del territorio catalán-; la capacidad para legitimar, basándose en dicha argumentación, la actuación armada frente al soberano; y el triunfo definitivo de toda esta presión sobre la figura momentáneamente empequeñecida del monarca de la Corona de Aragón, suponían una notable modificación en el juego de fuerzas habitual entre señor y súbditos. En consonancia con todo ello, la escenificación del regreso de Carlos de Viana a Barcelona -tras abandonar su prisión en Morella, en el reino de Valencia, donde su padre lo había confinado en febrero de 1461- no pudo evitar reflejar el pulso recién mantenido con Juan II, aunque sin perder nunca de vista las exigencias del código ceremonial de la ciudad.

En realidad, y a pesar de las apariencias, la espectacular entrada del príncipe en Barcelona, en marzo de 1461, no era tanto la recepción del ahora ya abiertamente reconocido como primogénito ${ }^{48}$, como la celebración del éxito de su liberación, con lo que ello tenía de autohomenaje y ostentación por parte de los que habían participado en ella, esto es, la Generalitat y el propio municipio barcelonés. A diferencia de Tortosa y Tarragona, ciudades en las que Carlos de Viana, en su trayecto desde Morella, había sido recibido con la solemnidad máxima -según correspondía a la primera visita de un primogénito al trono ${ }^{49}$-, Barcelona no contemplaba dicha opción, puesto que, tal como había sido recordado en sesión consistorial del 9 de marzo, el príncipe ya había sido acogido como tal en su entrada de 1460. Ahora, más allá de los gestos de alegría por su liberación, la ceremonia, intrínsecamente, debía ceñirse a la solemnidad mucho más modesta con la que se honraban las posteriores visitas de los miembros fundamentales de la familia real ${ }^{50}$. Y, sin embargo, sobre dicho esquema ceremonial básico y reconocible, se operó, al mismo tiempo, una llamativa transmutación, hasta el punto que tanto el habitual recibimiento institucional del visitante en el exterior de la ciudad como el protocolario recorrido por las calles del recinto urbano quedaron condicionados -casi sepultados- bajo el gran despliegue de orden militar que

\footnotetext{
${ }^{48} \mathrm{El} 7$ de febrero de 1461 -el mismo día en que se había aprobado por parte del Consell del Principat el reclutamiento de tropas para obtener la liberación del príncipe de Viana- el Consell de Cent barcelonés decidía otorgar a éste la titulación nominal de primogénito, en tanto que atribución «que Déu e natura li han donat», y obviaba definitivamente la voluntad contraria -y legítima- de Juan II (AHCB, CC, Deliberacions de guerra, III-1, f. 70r).

${ }^{49} \mathrm{La}$ entrada en Tortosa había tenido lugar el 4 de marzo de 1461, mientras que la recepción en Tarragona se celebró el 8 de ese mismo mes. En ambas ceremonias, de todos modos, la solemnidad y tradición celebrativas convivieron con las medidas de precaución diplomática y militar que imponía la inestabilidad política del momento. Para una inicial toma de contacto con dichas entradas, véase M. RAUFAST, ¿Recibir al primogénito?.

${ }^{50}$ Así ha quedado recogida dicha argumentación en los registros de deliberaciones del Consell de Cent barcelonés: «lo dit Concell deliberà, pus li era stada ja feta festa quan novament vench en Barchinona, ara no li·n sia feta, sino que sia receptat ab aquella honor que primogènit déu ésser receptat, ffahent e cantant per les sglèsies Te Deum laudamus de la sua delliurança, e encare fahent alimares per la ciutat e mostrant-ne aquella alagria que, de tant felicísima nova, mostrar-se déu» (AHCB, CC, Deliberacions de guerra, III-1, f. 100r).
} 
acompañó la ceremonia. Una demostración de fuerza cuya escenificación, por otro lado, reunía diversas lecturas: ¿orgulloso mensaje al derrotado Juan II, reivindicación del papel jugado por las tropas del Principado, o mero -pero aparatoso- ejercicio de precaución ante el peligro de cualquier reacción inesperada por parte del monarca? ${ }^{51}$.

El 12 de marzo de 1461, desde la cercana localidad de Sant Boi, el príncipe de Viana había iniciado la aproximación a Barcelona, discurriendo por un camino que, en su totalidad, aparecía flanqueado por hombres de armas, mientras que niños con cañas, espadas de madera y banderolas de papel interrumpían el paso del primogénito lanzando alabanzas a su persona y censurando la actitud de los malos consejeros de Juan II. Tras encontrarse con autoridades del Principado, consellers de Barcelona, representantes del clero y de la nobleza catalanas, y miembros de los estamentos del municipio, Carlos había penetrado en la ciudad y atravesado un escenario urbano inundado de milicianos y elementos armados del artesanado barcelonés hasta llegar a su alojamiento definitivo ${ }^{52}$.

Mediante la concesión final al primogénito del donativo que la intervención de Juan II había impedido hacer efectivo en $1460^{53}$, la ciudad de Barcelona daba por cerrado un ciclo ceremonial iniciado, en 1458, con la entrada de Juan II. Las recepciones solemnes ofrecidas al rey, a la reina y al heredero al trono configuraban una imagen global dinástica que, en teoría, debía resultar tranquilizante para el presente y el futuro del reino (y del municipio). Sin embargo, el coste real de todo ello, por lo mucho que se había puesto en juego, se revelaba, en esta ocasión, como un lastre insalvable de efectos completamente opuestos. En junio de 1461, tras la firma de la Capitulación de Vilafranca, Cataluña pasaba a contar con un soberano que, ahora, necesitaba del permiso de las instituciones catalanas para penetrar siquiera en el territorio del Principado, y con una reina limitada prácticamente a ejercer de intermediaria entre unos y otros, mientras que el primogénito aparecía, en tanto que lugarteniente perpetuo, como el verdadero depositario

\footnotetext{
${ }^{51}$ Inicialmente, Carlos de Viana había llegado hasta Tarragona acompañado de su madastra, la reina Juana -quien había sido la encargada de escenificar su Tiberación en el castillo de Morella el 1 de marzo-, y de un destacamento realista al mando del maestre de Montesa. Desde Barcelona se había trabajado, en todo momento, por separar al príncipe del resto de la comitiva. Finalmente, y ante la insistencia de los embajadores del Consell del Principat y de la propia ciudad, la reina Juana se había visto obligada a permanecer en Vilafranca del Penedés, mientras el primogénito se dirigía, custodiado por los embajadores catalanes, hacia el municipio barcelonés. Igualmente, en esas fechas, los rumores sobre posibles movimientos de tropas organizados por Juan II en las fronteras con Aragón y Navarra eran cada vez más frecuentes.

${ }^{52}$ El mismo 12 de marzo, consellers y diputados de la Generalitat habían coordinado la disposición escénica de las tropas participantes en la recepción (AHCB, CC, Lletres patents, VIII8 , f. 39r., con fecha original errónea de 1462 para las disposiciones de las autoridades barcelonesas; CODOIN (Levantamiento y guerra de Cataluña en tiempos de Juan II, vols. XVIXXVI, Barcelona, 1858-1864), XVI, pp. 5-6, para las de los diputados). El dietario de la Generalitat contiene la descripción coetanea más precisa que se conserva de esta entrada (véase J. M. SANS (dir.), Dietaris de la Generalitat, vol. I, p. 160). Acerca de la preparación y desarrollo de dicho evento, véase M. RAUFAST, ¿Recibir al primogénito?

${ }^{53}$ Puede encontrarse un detallada descripción de las piezas que componían la lujosa vajilla de plata entregada al príncipe de Viana en Llibre de les Solemnitats de Barcelona, vol. I, pp. 237 238.
} 
de la fidelidad a la monarquía ${ }^{54}$. Y aunque, a medio plazo -dada la edad ya avanzada de Juan II-, el nuevo escenario político presentaba una lógica irrefutable, la realidad es que, en el presente, el alcance de la conciliación resultaba tan inviable $-\mathrm{y}$, nos atreveríamos a decir, surrealista- como lo era, en definitiva -salvando las distancias-, aquella imagen del clero de Tàrrega, detenido en 1453 ante las puertas de la villa e imposibilitado de regresar al interior del recinto urbano, que veíamos en el apartado anterior de este artículo.

El inesperado fallecimiento del príncipe de Viana, en septiembre de 1461, acabó por descomponer aún más el frágil e irreal equilibrio surgido de la Capitulación de Vilafranca. En cumplimiento de lo allí pactado, era ahora el infante Fernando -primer hijo de Juan II con la reina Juana, y futuro Fernando II, a partir de 1479- quien, en tanto que nuevo primogénito, debía trasladarse rápidamente al Principado para asumir la función vacante de la lugartenencia general. Pero ahora, sin embargo, quien llegaba no era un hijo enfrentado a su padre, sino aquél que había sido designado por el monarca para ser su sucesor, y que, además, debido a su corta edad -apenas nueve años-, se presentaba obligatoriamente acompañado de su madre, la reina. Dichas circunstancias motivaron que, tras un proceso negociador previo marcado por la desconfianza y el recelo, la entrada de Fernando, junto a la reina, en Barcelona, a mediados de noviembre de 1461, fuese un fiel reflejo -en el cual no faltaban ni los desencuentros ni los fúnebres presagios- de la enrarecida atmósfera que dominaba, en aquellos momentos, la vida política de Cataluña ${ }^{55}$.

Procedentes de Martorell, a donde habían llegado tras su paso por Lleida y Cervera, la reina y el primogénito se habían instalado con celeridad en el monasterio de Valldonzella, el 13 de noviembre de 1461, sin esperar siquiera a ser recibidos institucionalmente por las autoridades barcelonesas. El intencionado desencuentro, en una maniobra mediante la cual la reina intentaba forzar su presencia, como tutora del infante Fernando, en la ceremonia de entrada de éste en Barcelona, había sido contestado, desde la

\footnotetext{
${ }^{54}$ La firma definitiva de la Capitulación de Vilafranca entre Juan II, el príncipe de Viana y las instituciones del Principado tuvo lugar el 21 de junio de 1461. Casi inmediatamente, el 24 de ese mismo mes, Carlos dẹ Viana juró en Barcelona el cargo de lugarteniente general en Cataluña, mientras que el 30 de julio se celebró, en la misma ciudad, la solemne ceremonia por la que era reconocido oficialmente como primogénito al trono, a pesar de la protesta de Juan II ante la ilegitimidad de dicha proclamación. Para un intento de análisis del contenido y consecuencias políticas de la Capitulación de Vilafranca, véanse G. DESDEVISES, Don Carlos de Aragón, pp. 383-390; J. VICENS VIVES, Juan II de Aragón, pp. 228-232.

${ }^{55}$ A finales de septiembre de 1461 , la Generalitat daba ya instrucciones a sus embajadores para que insistieran ante Juan II acerca de la posibilidad de que el infante Fernando pudiese viajar solo, sin la compañía de su maḍre, hasta Barcelona, en lo que era un intento, esta vez sin ệxito, de repetir una operación similar a la que había tenido lugar en 1461 con el príncipe de Viana y la propia reina Juana (ACA, Generalitat, reg. 904, f. 108r. Barcelona, 1461, septiembre, 29). Por su parte, en noviembre, el monarça, desde Calatayuḍ, seguía manif̣estanḍo sus dudas a la reina sobre la conveniencia de que el infante y ella continuasen su viaje hacia Barcelona, una vez llegados a Lleida y jurado allí Fernando como primogénito (ACA, C, reg. 3411, f. 33r. Calatayud, 1461, noviembre, 9). Ambos documentos han sido tratados en Nuria CoLL JULIÀ, Doña Juana Enriquez, 2 vols., Madrid, 1953, obra a la cual remitimos para todo lo referente a la negociación, preámbulos y materialización final de la entrada de Fernando, como primogénito, en Barcelona.
} 
ciudad, con el recurso a la parsimonia diplomática: a pesar de su presura inicial, los ilustres visitantes se vieron finalmente conminados a permanecer recluidos en Valldonzella -a unos cientos de metros de las puertas de la ciudad-por espacio de ocho días hasta que los diputados de la Generalitat y el consistorio municipal, tras la revisión minuciosa del texto de la Capitulación de Vilafranca, consideraron que nada se oponía a que la reina Juana actuase como tutora del infante en los actos de la celebración y permitieron que comenzasen a ultimarse los preparativos de la misma.

El 21 de noviembre, por fin, el férreo hermetismo de la ciudad desaparecía y Fernando, siempre seguido de cerca por su madre, entraba en Barcelona con la solemnidad que correspondía a la primera visita del primogénito al trono. El modelo de la recepción ofrecida en honor de su padre, Juan II, en 1458 volvía -al igual que había sucedido con motivo de la entrada del príncipe de Viana en 1460- a ser convocado: penetrando por el Portal de les Drassanes, el infante había llegado hasta la plaza de Framenors para, tras encontrarse allí con los consellers, acceder al catafalco profusamente ornamentado desde el cual iba a contemplar el desfile de los oficios barceloneses. Finalizada la exhibición artesanal ${ }^{56}$, el primogénito había recorrido, bajo palio, precedido por la espada real ${ }^{57}$, custodiada su montura por autoridades y personalidades, y anunciado por músicos y juglares, el tradicional itinerario ceremonial que conducía hasta la Catedral, a través de la calle Ample, la plaza del Born, la calle de Montcada, la calle de la Bòria y la plaza de Sant Jaume. En las inmediaciones de la Seu, el clero en procesión había acudido a recibir a Fernando y, luego, lo había acompañado hasta el interior del templo para asistir y participar en la liturgia habitual y conocida para este tipo de eventos, dentro de la cual, entre cantos corales y el sonido imponente de los órganos, se incluía la visita ritual a la capilla de Santa Eulalia, patrona de la ciudad. Por último, ya a pie, el infante y la reina habían sido acompañados por los consellers hasta su alojamiento en el cercano Palacio Real, acto con el cual se había dado por concluida una ceremonia cuyo correcto desenlace ${ }^{58}$ no podía borrar, en ningún caso, ni el escaso brillo de sus

\footnotetext{
${ }^{56} \mathrm{La}$ cual, según el testimonio dejado por el escribano de la Generalitat, Jaume Safont, no pareció tener el lucimiento de las grandes ocasiones: «E aprés passaren les confraries dels manestrals, quascuna ab son standart, sens alguns castells ne altres entrameses, sinó un castellot mal fet, tot cubert de rama que·y feren la confraria dels bossers» (J.M. SANS (ed.), Dietari o Llibre de Jornades, p. 143).

${ }^{57}$ «e denant lo dit primogenit anava don Johan de Prades, fill del comte de Prades e camerlench del dit senyor primogenit, portant-li una spasa denant ab pom mantí e croera deurats, lansade sus lo coll, ab lo pom alt» (Llibre de les Solemnitats de Barcelona, vol. I, p. 259). Ácerca de la importancia adquirida por este elemento como símbolo de la monarquía catalanoaragonesa, en detrimento de la corona real, véase Bonifacio PALACIOS MARTíN, Los símbolos de la soberanía en la Edad Media española. El simbolismo de la espada, en VII Centenario del Infante Don Fernando de la Cerda, Madrid, 1976, pp. 283-287.

${ }^{58}$ Así era como describía la propia reịna, en carta a Juan II, el evento en su conjunto: «En el dicho monasterio stuvimos yo e el illustrissimo principe primogenito, fijo nuestro, por causa de preparatorio que se fazia de la recepcion, fasta ayer sabado, que yo e el dicho principe entramos en aquesta ciutat de Barchinona; somos stados recibidos en ella con muy gran fiesta, alegria, reposo e celebritat por todos los que en ella se han trobado. E han sallido todos los oficios, con banderas, a la plaça de Frayres Menores, en do fue fecho el cadafalto, e levado en palio, como se acostumbra a primogenito, a la Seu, e depues al palacio mayor, en do stamos aposantados»
} 
preámbulos, ni los inquietantes detalles que habían poblado el desarrollo de la misma ${ }^{59}$.

Poco más tarde, en los primeros meses de 1462, los acontecimientos se precipitarían y, de ese modo, la entrada del primogénito en Barcelona quedaría ligada para siempre al inicio de la Guerra Civil Catalana. En diciembre de 1461, tras jurar, como tutora de Fernando, tanto la Capitulación de Vilafranca como los privilegios municipales de la ciudad, la reina planteaba al consistorio barcelonés la conveniencia del regreso de Juan II al Principado. A finales de febrero de 1462, eran los miembros del partido de la Busca -desplazados del poder municipal de la mano de la nueva coyuntura política y de su correspondiente aprovechamiento por parte de la oligarquía bigairelos que intentaban promover el retorno del monarca, dinamitando así definitivamente el inconsistente y forzado equilibrio nacido de las negociaciones de 1461. En marzo de 1462 , la reina y el primogénito abandonaban precavidamente Barcelona, en dirección a Girona, mientras la represión se desataba en el interior de la ciudad contra los afines a Juan $\mathrm{II}^{60}$. En junio, en plena escalada de tensión, tanto el rey como la reina eran declarados enemigos del Principado. A esas alturas, las tropas organizadas por la Generalitat ya apuntaban hacia ambos, en una nueva demostración de fuerza que, probablemente, se inspiraba en el éxito de lo sucedido un año atrás durante la campaña para la liberación del príncipe de Viana ${ }^{61}$. En julio, sin embargo, la contra-

(ARV, Gobernación, Lletres secretes, reg. 2.809, f. 45v. 1461, noviembre, 22. Barcelona. Reproducimos aquí la transcripción que, del documento aparece en Miguel GUAL CAMARENA, Fernando el Catolico primogénito de Aragón, rey de Sicllia y príncipe de Castilla (1452-74), "Saitabi", 8 (1950-51), p. 187).

${ }^{59}$ A la tensión previa por la presencia de la reina en la celebración, habría que añadir la evocación permanente que, de la figura del fallecido príncipe de Viana, se hizo durante toda la jornada -su hijo natural, el conde de Beaufort, había ocupado un destacado lugar en la comitiva ceremonial, mientras que el infante Fernando y la reina habían tenido que visitar la sepultura del príncipe en el interior de la Catedral-, así como la susceptibilidad con la que parecieron ser interpretados algunos de los incidentes ocurridos a lo largo de la misma -por ejemplo, la caída de columnas y rotura de cuerdas de campanario durante la estancia del primogénito en la Seu barcelonesa. Puede encontrarse una pormenorizada descripción de dicha entrada tanto en Llibre de les Solemnitats de Barcelona, vol. I, pp. 254-261, como en J. M. SANS (ed.), Dietari o Llibre de Jornades, pp. 143-144.

${ }^{60}$ El fracaso del "Complot de San Matías", que implicaba a destacados representantes de la Busca y salpicaba igualmente a la figura de la reina Juana, acabó forzando la partida de ésta y del primogénito hacia Girona, con la excusa de intervenir en la resolución del conflicto remença que afectaba el área rưral del norte del Principado, y supuso el ingreso en prisión -cuando no la muerte por ejecución- de muchos de aquellos -incluidos consellers y otros cargos públicos- que habían podido figurar, no hacía mucho, ocupando lugares destacados en las ceremonias de entrada de Juan II, del príncipe de Viana o del infante Fernando en la ciudad. Acerca de todo este agitado proceso, véanse C. BATLLE, La crisis social y económica de Barcelona a mediados del siglo XV, vol. I, p. 360-369; N. Coll Julià, Doña Juana Enríquez, vol. I, pp. 219-240.

${ }^{61}$ El 9 de junio de 1462 , la Generalitat, tras condenar la alianza de Juan II con el rey de Francia para atacar el Principado, así como su colaboración con el movimiento remença, entre otras graves acusaciones, declaraba al monarca, y a todos sus seguidores, «enemichs de la cosa pública del dit Principat» El 11 de ese mismo mes, la reina pasaba, igualmente, a ser considerada como «enimiga, discipadora, destruhidora e subvertidora, no solament del patrimoni reyal, ans encara de la cosa pública del dit Principat e de les libertats de aquell» (J. M. SANS (ed.), Dietari o Llibre de Jornades, p. 158-160). El 24 de junio, los consellers de Barcelona, mientras el ejército del Principado asaltaba ya Girona, donde se encontraban refugiados la reina y el primogénito, había llegado a sopesar la posibilidad de presionar a ésta para quẹ, por la seguridad del infante, pusiese a Fernando en manos de las autoridades del propio Principado, puesto que, en definitiva, se trataba de aquél que, en el futuro, estaba destinado a ser el nuevo rey de los catalanes (AHCB, CC, Deliberacions, II-14, f. 140v). 
ofensiva militar realista anunciaba que, esta vez, todo iba a ser diferente. En agosto, Barcelona comenzaba a adoptar la fisonomía de una ciudad amenazada (véase nota 16). En septiembre, Juan II se presentaba ante sus murallas y la sitiaba. La Guerra Civil Catalana había dado comienzo.

La dramática fractura política, los bruscos giros dinásticos que se producirían en los años inmediatos, así como la propia dinámica del conflicto, originarían igualmente una clara ruptura en el orden de lo ceremonial. La valiosa y defendida tradición en el ritual de entrada real en Barcelona habría de compartir protagonismo, ahora, con importantes variaciones que, en el fondo, no harían más que evidenciar el rumbo tomado por los acontecimientos.

\section{EL CONFLICTO Y SUS CEREMONIAS}

(1462-1471)

El 12 de junio de 1471, el hijo bastardo del fallecido Juan de Anjou llegaba a Barcelona como lugarteniente de su abuelo, el rey Renato de Anjou, en Cataluña ${ }^{62}$. En la tarde de ese día, en la que iba a ser la última ceremonia de entrada celebrada en la ciudad antes de su rendición ante Juan II, los consellers y las autoridades del Principado habían acudido a recibir al peculiar enviado del monarca a las afueras del recinto urbano. A ojos de Jaume Safont, el escribano de la Generalitat testigo del hecho, dicha decisión, por inusual y poco acorde a la categoría de la propia ciudad, era un verdadero atentado a la tradición ceremonial del municipio. Tanto, que, en opinión de Safont, ésta quedaba irremediablemente tocada de muerte desde aquel mismo instante ${ }^{63}$.

En realidad -y Safont no podía ignorarlo, puesto que él fue uno de los principales cronistas de la práctica institucional cotidiana del municipio entre 1454 y $1472^{64}$-, el conjunto de la actividad ceremonial de Barcelona se había

\footnotetext{
${ }^{62}$ Renato, duque de Anjou, conde de Provenza, tío de Luis XI de Francia, y nieto, por línea materna, de Juan I de Aragón, había aceptado en 1466 la oferta de las instituciones catalanas para convertirse en el nuevo señor del Principado, en sustitución del desaparecido Pedro de Portugal. Había sido, en cualquier caso, su primogénito, Juan, duque de Calabria, quien se había desplazado hasta Cataluña para dirigir las operaciones militares contra las fuerzas de Juan II. A la muerte del duque de Calabria, y quizás ante el cariz desfavorable que tomaba en aque momento el curso de la guerra, Renato había preferido enviar como sustituto al hijo natural de fallecido, Juan, miẹntras Nicolás, el verdadero sucesor del primogénito, permanecía en Francia. Acerca de la relación y presencia de la Casa de Anjou en el Principado, entre 1466 y 1472 , véanse J. CALMETTE, Louis XI, pp. 265-347; Francina SolsonA CLIMENT, Aspectos de la dominación angevina en Cataluña (1466-1472), "Cuadernos de Historia Jerónimo Zurita", 14-15 (1963), pp. 31-54; Jacques BÉNET, Jean d'Anjou, duc de Calabre et de Lorraine (1426-1470), Nancy, 1997, pp. 113-128; A. RYDER, The Wreck of Catalonia, pp. 175-225.

${ }^{63}$ «entrà en la ciutat de Barchinona lo il-lustre don Johan de Calàbria, fill bestart del il-lustríssimo don Johan de Calàbria, primogènit d'Aragó e de Sicília, de loable recordació Isqueren-li a reebre los consellẹrs e deputats, de què molts se meravellaren, car no és custum de la ciutat exir a fill de rey qui sie bastart, perquè de huy avant podem dir que bona glòria hajen totes les antigues e bones serimònies de Barchinona» (J.M. SANS (dir.), Dietaris de la Generalitat, vol. I, p. 202).

${ }^{64}$ Tanto a través del Dietario de la Diputación del General -registro oficial emanado de la escribanía mayor de la Generalitat-, como de la redacción, a partir de las anotaciones de dicho registro oficial, de su propio dietario personal. Sobre la figura y la obra de Jaume Safont, véase J. M. SANS (ed.), Dietari o Llibre de Jornades, pp. IX-CII.
} 
visto sometido a significativas modificaciones desde el inicio de la Guerra Civil en 1462. En una ciudad que se debatía entre el temor al enemigo exterior y la desconfianza respecto a la fidelidad de sus propios habitantes, el mismo pulso diario de ésta había de cobrar, por fuerza, un sentido diferente. El conflicto del Principado con Juan II había pasado a ser, en definitiva, el nuevo eje sobre el cual giraba la vida pública de Barcelona. Ese preciso contexto, en la misma medida que requería nuevas específicas ceremonias, imponía igualmente que las ya preexistentes y habituales de la ciudad se adaptaran a sus necesidades y exigencias.

Así, por ejemplo, el tradicional fervor procesional de la Barcelona bajomedieval había tendido a expresar, a lo largo de estos años, una sensibilidad sociopolítica - promovida, obviamente, desde el gobierno municipal- que bebía directamente de las aguas del conflicto: el beneficio general de la ciudad en su enfrentamiento con Juan II $^{65}$, las victorias militares contra las fuerzas realistas ${ }^{66}$, o la llegada -ya en las postrimerías de la conflagración, con Barcelona a punto de claudicar ante el sitio al que la sometía el monarca- de provisiones por mar ${ }^{67}$, fueron motivo, en uno u otro momento, de expresiones colectivas de devoción cívico-religiosa que, en forma de ceremonias procesionales, recorrían las calles de la ciudad intentando conjugar la intervención divina con la necesidad, cada vez más imperiosa, de convocar imágenes efectivas de la cohesión del cuerpo social urbano $^{68}$.

Por el contrario, la manifestación procesional por excelencia de la ciudad en el siglo XV -aquella que tenía lugar, cada año, el día de la celebración del Corpus- vio como, desde el inicio de la guerra, su tradicional esplendor se veía notoriamente reducido y, tras perder sus elementos más

${ }^{65} \mathrm{El} 19$ de noviembre de 1463 , los consellers de Barcelona convocaban a la población de la ciudad a participar, al día siguiente, en una procesión en la que se pretẹndía invocar la ayuda divina para poder «endreçar los affers e negocis de la present ciutat e Principat de Cathalunya, en tal manera que succehescha pau, tranquil-litat e repós» (AHCB, CC, Ordinacions, IV-9, f. 37rv). El 19 de marzo de 1466, ante los estragos de la peste, tres habían sido las procesiones que, en días sucesivos, fueron programadas a fìn de «pus fàcilment obtenir gràcia e mercè de Nostre Senyor Déu e de la sua beneyta mare en les multiplicades tribulacions en les quals aquesta ciutat, per peccats e deffalliments, és constituida» (ibídem, ff. $71 \mathrm{v}-72 \mathrm{r}$ ). Igualmente, el 20 de octubre de 1462, las autoridades barcelonesas habían reclamado una mayor intensidad en la celebración de las festividades de Santa Eulalia o de San Miguel, dada la necesidad del momento: «com nunqua aquesta ciutat fonch constituida en més necẹssitat de obtenir la ajuda divinal e de sos beneyts Sants... a ffi que Nostre Senyor Déu, per intercessió dels dits Sants, vulle endreçar los fets concorrents» (AHCB, CC, Deliberacions, II-15, f. 39r)

${ }^{66} \mathrm{El} 26$ de noviembre de 1467. Barcelona celebraba, mediante procesión general, la derrota de las tropas realistas en Viladamat (Girona, 21 de noviembre de 1467) (AHCB, CC, Ordinacions, IV-9, f. 107v). Igualmente, el 30 de mayo de 1469, con motivo de la conquista de la ciudad de Girona, los consellers barceloneses habían determinado que, durante tres días, se conmemorase el hecho con procesiones y festejos populares (ibídem, f. 136v).

${ }^{67}$ AHCB, CC, Ordinacions, IV-10, ff. 16v-17r. 1472, marzo, 17.

${ }^{68}$ Acerca de las prácticas procesionales en la Barcelona bajomedieval, véanse Jordi FERNÁNDEZ CUADRENCH, Les processons extraordinàries a la Barcelona baixmedieval (13391498). Assaig tipológic, "Ảcta Historica et Archaeologica Mediaevalia”, 26 (2005), pp. 403-428; Miguel RAUFAST CHICO, Itineraris processionals a la Barcelona baixmedieval "Revista d'Etnologia de Catalunya», 29 (2006), pp. 134-146. Asimismo, para un interesante análisis de los mecanismos procesionales en la sociedad urbana bajomedieval, véase Jacques CHIFFOLEAU, Les processions parisiennes de 1412. Analyse d'un rituel flamboyant, "Revue Historique", 284 (1990), pp. 37-76. 
llamativos -los entremeses o representaciones escénicas que acompañaban dicha procesión- y experimentar modificaciones en el trazado de su característico recorrido urbano por las calles de Barcelona, pareció ceder protagonismo, durante este tiempo, en favor de iniciativas más inmediatas y puntuales como podían ser las procesiones que acabamos de comentar ${ }^{69}$.

Llamamientos a la participación armada de la población ${ }^{70}$; recepciones ofrecidas a los mandos y tropas del Principado ${ }^{71}$; o escenificaciones públicas de condena a los traidores ${ }^{72}$, procedieron a ensanchar, igualmente, el espectro ceremonial de la ciudad, mientras que la peculiar apuesta política de Cataluña en dicho período iba quedando reflejada, mediante la alegría y el luto oficiales, a través de los actos con los que Barcelona acogía y despedía a sus nuevos señores ${ }^{73}$.

${ }^{69}$ El 14 de junio de 1462 , desde el consistorio barcelonés se había dispuesto que, ese año, la procesión del día del Corpus quedase limitada a su mínima expresión: «que, aquesta vegada, no sia feta segons lo acustumat, ans, lo dit die, la processó sia feta tensolament per lo honorable clero de la Seu, sens luminaria de confraries, trahent la custodia de aquella e passant-la per aquells carrers e lochs hon la processó acustume de passar quescun any lo die de la Concepció de Nostra Donà (AHCB, CC, Ordinacions, IV-8, f. 179r-v). No sería hạsta dos años después de la finalización del conflicto cuando dicha procesión recuperaría su imagen habitual. As quedaba establecido, de manos de las autoridades municipales, el 2 de junio de 1474: «com per alguns dels anys passats, causant lo error de les guerras, la celebritat de la processó de Corpore Christi, en quant toquave les representacions, fos stade intermissa e cessade, e ara lo Concell ordinari de la dita ciutat, considerant la grandíssima gràcia Nostre Senyor Déu li ha atorgada de ésser restituida la pau, haje ordonat la ditạ celebració esser ab tota integritat, en la present anyada, tornade e feta» (AHCB, CC, Ordinacions, IV-10, ff. 52v-53r). Para una aproximación a la celebración del Corpus en la Barcelona bajomedieval, véase Agustí DURAN I SANPERE, La fiesta del Corpus, Barcelona, 1943.

${ }^{70}$ El 21 de mayo de 1464 , Pedro de Portugal -nuevo monarca del Principado desde principios de ese mismo ano-, en virtud de la potestad que le otorgaba el Princeps namque (usatge que concedía al soberanó la facultad de reclamar la inmediata participación de sus súbditos en defensa del territorio), había ordenado que se hiciera convocatoria pública, por las calles de Barcelona, para acudir en socorro de la ciudad de Lleida, sitiada en aquel momento por las tropas de Juan II: «e lo dit vaguer o Regent anava per la dita Ciutat a cavall ab sobrevesta reyal, e devant ell anaven molts saigs cridant a grans veus viafos princeps namque, e portaven falles de foch enceses e axi discorrian la dita Ciutat» (Manual de Novells Ardits, vol. I1, pp. 449-450). Similar ritual sería escenificado el 1 de noviembre de 1467, esta vez bajo el reinado de Renato de Anjou, con motivo de la campaña militar en el Empordà (ibídem, p. 482).

${ }^{71}$ Așí había sucedido el 13 de enero de 1463, cuando las tropas organizadas bajo la bandera de la ciudad que habían luchado en Tàrrega regresaron a Barcelona: «axiran los honorables consellers fins al coll de la creu e acompanyaren lo dit capita ab la dita bandera fins a la casa de la present Ciutat» (ibídem, p. 425). Parecida distinción había tenido Francesc Junyent, conseller de la la ciudad, el 13 de octubre de 1466, al desembarcar en la playa de Barcelona como capitán de un pequeño destacamento naval: «axi en terra ab la barca armada, e II altres barques ab trompetes e los consellers e deputats a peu reberan aquell exint de mar ab tres trompetes de la Ciutat, e axi ab les trompes sonant acompanyat dels demunt dits e molts altres sen intra dins lotge, e poch apres parti de lotge sens los consellers e deputats acompanyat de molta gent ab les trompetes devant sen ana a casa sua» (ibídem, p. 472).

${ }^{72}$ El 17 de julio de 1462, la imagen invertida de Joan Agulló, síndico de Lleida, había sido pintada en el patio de la casa consistorial, así como en diversas plazas de Barcelona, para expresar la condena de dicho personaje por su traición a la causa del Principado (ibídem, p. 413). Igualmente, el 23 de noviembre de 1471, imágenes de trapo, representando los cuerpos de aquellos que habían entregado Girona al enemigo, habían sido arrastradas por toda Barcelona, precedidas por los gritos que reclamaban insistentemente la muerte de dichos traidores (J.M. SANS (ed.), Dietari o Llibre de Jornades, pp. 226-227).

${ }^{73}$ El 8 de julio de 1466 tenían lugar en la ciudad las exequias fúnebres en honor del rey Pedro de Portugal, fallecido el 29 de junio de ese año (Llibre de les Solemnitats de Barcelona, vol. I, pp. 280-285). El 21 de diciembre de 1470 volvía a escenificarse una ceremonia similar, ahora con motivo de la muerte de Juan de Calabria, primogénito del rey Renato de Anjou y lugarteniente suyo en el Principado, el día 16 de aquel mismo mes (J.M. SANS (ed.), Dietari o Llibre de Jornades, pp. 220-222). Entremedias, Barcelona había celebrado, a finales de octubre de 1466, 
Finalmente, en una ciudad cuya integridad pasaba a depender, de manera directa y literal, de la consistencia de sus murallas ${ }^{74}$, de la infranqueabilidad de sus accesos ${ }^{75}$, del mantenimiento de un estado de alarma casi permanente $^{76}$, y de la depuración incesante del más mínimo atisbo de defección interna ${ }^{77}$, no resultaba, por tanto, extraño que, en el período que nos ocupa, toda ceremonia de entrada en ella acabase compartiendo protagonismo con la correspondiente, paralela y aparentemente antagónica preocupación de

la aceptación, por parte de Renato de Anjou, del trono ofrecido por las autoridades del Principado. En carta fechada el 4 de noviembre de dịcho año, los consellers barceloneses informaban al nuevo monarca cómo, tras conocer la noticia, un solemne acto religioso había sido dispuesto en la Catedral, mientras la ciudad iniciaba dos jornadas llenas de festejos y manifestaciones de alegría ante la llegada de dicha nueva: «ab los deputats de Cathalunya, acompanyats de gran multitud de poble, som anats a la Seu, sglèsia cathedral d'aquesta vostra ciutat, en la qual lo clero d'aquella, molt devotament decantant lo Te Deum laudamus, ffahent lahors a Nostre Senyor Déu de tanta gràcia d'ell obtenguda d'haver tal e tant virtuós rey e senyor, e més, lo dit die, ẹ lo aprés següent, són stades fetes en aquesta ciutat grans alimares e alegries, e no crehem los vivents hajen memòria haver vist lo poble minça tant alegrar-se de qualsevol noves e novelles entrades de reys com han fet d'aquesta» (AHCB, CC, Lletres closes, VI-23, ff. 80v-81r).

${ }^{74} \mathrm{El} 4$ de septiembre de 1462, ante la proximidad de las tropas enemigas que, poco después, habían de poner sitio a la ciudad, el consistorio barcelonés había ordenado derribar todo aquel edificio o construcción exterior que, por su proximidad, pudiera enturbiar la correcta defensa de perímetro amurallado (AHCB, CC, Deliberacions, II-15, f. 29v). Aún así, durante la Guerra Civil Catalana, Barcelona tan sólo experimentó una amenaza bélica directa en el inicio (1462) y el final (1471-1472) de dicho conflicto.

${ }^{75} \mathrm{El} 8$ de octubre de 1467, dos habitantes de Barcelona habían sido ejecutados públicamente, acusados de haberse hecho, de manera clandestina, con las llaves de uno de los portales de la ciudad para intentar facilitar la entrada en ella de las tropas realistas de Juan II (J.M. SANS (ed.), Dietari o Llibre de Jornades, p. 211).

${ }^{76} \mathrm{El}$ escaso rigor inicial con el que se llevaban a cabo las tareas de vigilancia armada de la ciudad había llevado a los consellers de Barcelona a exigir, el 17 de julio de 1462 , que éstas se efectuasen con la misma intensidad con que se habían realizado, en 1461, en la época del conflicto del príncipe de Viana con Juan II: "segons se fahien en temps que vivia lo beneventurat Sanct Carles, primogènit» (AHCB, CC, Deliberacions, II-15, f. 1r). El 8 de julio de 1466 , en plena Guerra Civil, Tas autoridades barcelonesas habían tenido que volvẹ a intervenir para garantizar la correcta ejecución de las guardias nocturnas en el interior del recinto urbano, «per quant se veu que les guaytes de nits no: $s$ fan per los qui convidats hi són, axí ab aquella diligència e sol·licitud gue-s pertany es deurien fer» (AHCB, CC, Deliberacions, II-17, f. 108v). Y el 28 de diciembre de 1471 , ya con la ciudad sitiada por las tropas de Juan II, una nueva disposición consistorial reclamaba la máxima colaboración de la población en las tạreas de defensa, y se veía obligada a prohibir -en lo que era una chocante imagen, totalmente alejada de la posible épica del momentoque nadie utilizase lo alto de las murallas para, entre otras cosas, tender ropa lavada: «que alguna persona, hom o dona, qui no sien destinats en fer algun exercici de la deffenció dessús dita, no s'atrevescha ni gos pujar a les muralles per stendre bugades, o per mirar, o per altre qualsevol exercici» (AHCB, CC, Ordinacions, IV-10, f. 10r).

${ }^{77}$ El 2 de julio de 1466, pocos días después de la muerte del rey Pedro de Portugal, una ordenanza pública reçordaba a los habitantes đe Barcelona la estricta prohibición de hablar a favor de Juan II, estableciendo la pena de muerte para aquél que contraviniera dicha disposición (Manual de Novells Ardits, vol. II, p. 471). El 19 de noviembre de 1471, los abades de Montserrat y de Sant Cugat, entre otros, habían sido detenidos, acusados de conspiración, y expulsados de la ciudad -y del Principado - en una nave que había de llevarlos hasta la Provenza francesa y que, supuestamente, nunca llegó a su destino: "foren mesos tots V en la barcha de la dita nau e recullitș en aquella, que sol no ls lexaren anar a lurs cases ne comunicar ab algú. E pochs dies aprés s'ic sabe que tots eren negats, e la nau perduna, que no:n campà persona alguna» (J. M. SANS (ed.), Dietari o Llibre de Jornades, p. 225). El 24 de septiembre de 1472 , ya en los últimos compases del conflicto, había sido el propio conde de Pallars, uno de los grandes líderes militares del Principado, quien se había visto obligado a abandonar furtivamente Barcelona ante la inminencia de su detención, acusado de tratar en secreto con Juan II (J. M. SANS (dir.), Dietaris de la Generalitat, vol. I, p. 126). 
las autoridades municipales por garantizar, al mismo tiempo, el hermetismo del propio recinto urbano ${ }^{78}$.

De hecho -y Safont tampoco podía desconocerlo, dado que él mismo fue testigo y nos ha dejado testimonio de ello-, ninguna de las ceremonias de entrada celebradas en Barcelona en el período comprendido entre 1462 y 1472 respondió a lo que podía esperarse tradicionalmente de un evento de este carácter. En algunos casos, sencillamente, ni siquiera hubo ocasión para que la ciudad pudiese llegar a escenificarlas.

\section{1462-1466}

La inicial aceptación, por parte de Enrique IV de Castilla, del trono que le ofrecían las instituciones catalanas, una vez retirada la fidelidad a Juan II, nunca llegó, en realidad, a traducirse en un encuentro real y físico entre monarca y territorio, en lo que era una clara muestra de la provisionalidad y prudencia diplomática que rodeó a dicho contrato político ${ }^{79}$. La llegada por mar desde Tortosa, el 24 de octubre de 1462, de Juan de Beaumont y Juan Ximénez de Arévalo a Barcelona, en calidad de procuradores del monarca castellano, tan sólo pareció dar lugar a una simple recepción institucional, ajustada a la categoría de los visitantes y muy alejada del gran festejo que hubiera acompañado la llegada del propio soberano ${ }^{80}$.

Festejo que sí se materializaría, aunque en una forma nada habitual, con motivo de la llegada, a inicios de 1464, del nuevo monarca elegido por el Principado, tras la renuncia al trono de Enrique IV de Castilla. El 21 de enero de dicho año, ya en el anochecer del día, desembarcaba en la playa de Barcelona, procedente de Ceuta, el Condestable Pedro de Portugal, dando pie a una celebración sorprendentemente fragmentada y discontinua que, al descomponer la cohesión dramática de la ceremonia, parecía constituirse en reflejo ritual, no sólo de la fracturada realidad política del momento, sino

\footnotetext{
${ }^{78}$ Así quedaba, al menos, de manifiesto - tal como lo refiere Jaume Safont- con motivo de la fiesta ofrecida por Barcelona al rey Pedro de Portugal a su llegada a la ciudad, a finales de enero de 1464: «E no'm vull oblidar de fer ací menció e memòria com tot aquest die los consellers ordonaren que tots los portals de la ciutat stiguessen tencats, així com de fet stigueren, perquè com en aquests dies tot lo Principat de Cathalunya era en guerra, e stàvem ab les armes adòs contra lo rey Johan Sens Fe e sos sacassos» (J.M. SANS (ed.), Dietari o Llibre de Jornades, pp. 189-190).

${ }^{79}$ Enrique IV había aceptado la oferta del Principado a finales de agosto de 1462 y, unas semanas después, el 11 de septiembre de ese año, había designado a Juan de Beaumont y a Juan Ximénez de Arévalo como procuradores suyos en Cataluña, conjuntamente con el envío de tropas de auxilio. Tras su llegada a Barcelona, ambos habían jurado, en nombre del monarca castellano, los privilegios de la ciudad y del Principado, y habían recibido el correspondiente juramento de fidelidad por parte de las instituciones catalanas. En 1463, sin embargo, los acuerdos diplomáticos entre Castilla y Francia, que hasta ese momento apoyaba la causa de Juan II en el conflicto, desembocaron en la renuncia oficial de Enrique IV al trono, a pesar de que Juan de Beaumont continuaría desempeñando el cargo de lugarteniente del monarca hasta inicios de 1464. Acerca de la participación de Enrique IV de Castilla en la Guerra Civil Catalana, véanse J. CALMETTE, Louis XI, pp. 170-202; J. VICENS VIVES, Juan II de Aragón, pp. 278-290; Jaume SOBREQUÉS I CALLICO, Enric IV de Castella, senyor del Principat de Catalunya, Barcelona, 1989; A. RYDER, The Wreck of Catalonia, pp. 124-150.

${ }^{80}$ Apenas nada ha quedado registrado sobre dicha acogida, excepto la simple constancia del hecho y un escueto comentario sobre su repercusión: «e de la lur venguda fou gran elegria en la present Ciutat» (Manual de Novells Ardits, vol. II, p. 420).
} 
también de la nueva relación de fuerzas que, tras el rechazo a la figura de Juan II, existía en el Principado entre las instituciones catalanas y la monarquía ${ }^{81}$.

Desde el 14 de enero de 1464, los consellers poseían información fidedigna sobre la inminencia de la llegada del nuevo soberano y, ese mismo día, ya se había deliberado en el consistorio municipal acerca de la construcción tanto del puente de madera destinado a acoger al visitante cuando éste abandonase la nave en la que viajaba, como del catafalco honorífico en el cual el monarca había de jurar los privilegios de la ciudad y contemplar el desfile de los oficios artesanales barceloneses, sin olvidar la designación y acondicionamiento del que iba a ser su inicial alojamiento en casa del ciudadano Bernat de Gualbes ${ }^{82}$. Y sin embargo, una semana más tarde, cuando Pedro de Portugal se presentó frente a la playa de Barcelona, pareció como si nada de todo ello hubiese servido para acabar de configurar y definir la prevista ceremonia. En su lugar, tuvieron que transcurrir seis días desde que el rey entró en la ciudad hasta que pudo darse por concluida una celebración que, normalmente, había de ocupar tan sólo una única jornada.

Si tomamos como guía el testimonio de Jaume Safont -no en vano su descripción de la ceremonia de la entrada de Pedro de Portugal ha quedado, sin ningún género de dudas, como uno de los más coloristas y vívidos retratos que poseemos de un evento de estas características en la Barcelona bajomedie$\mathrm{val}^{83}$-, nos encontramos, en el anochecer del sábado 21 de enero de 1464, con un mar agitado que impide a la nave del soberano aproximarse a la playa y

\footnotetext{
${ }^{81}$ Hijo del infante Pedro de Portugal y nieto, por línea materna, del conde de Urgell -uno de los candidatos al trono de la Corona de Aragón en tiempos del Compromiso del Caspe, tras la muerte de Martín el Humano en 1410-, el Condestable ya se había ofrecido, como sustituto de Juan II a las instituciones del Principado en 1462, aunque entonces el ẹlegidó había sido Enrique IV de Castilla. Fracasada la apuesta castellana, y después de tantear, sin exito, la opción de Luis XI de Francia, las autoridades catalanas habían vuelto su mirada hacia el príncipe portugués y le habían ofrecido la corona, no ya del Principado, sino del conjunto de la Corona de Aragon, el 27 de octubre de 1464. Las naves enviadas por el Principado, el 30 de octubre, a Portugal para recoger al Condestable se habían encontrado con éste en Ceuta, adonde había llegado formando parte de la expedición militar portuguesa del rey Alfonso V contra Tánger. No sería hasta principios de enero de 1464 cuando la pequeña comitiva naval partiría finalmente en dirección a Barcelona (el viaje de las mencionadas naves aparece resumido, en palabras de quien estaba al mando de ellas -Rafael Julià-, en las actas municipales de la época: «E partim de la plage de Barcelona a XXX del mes d'octubre, e som arribades en Barcelona, ab lo dit senyor rey, a XXI del mes de janer, que són dos mesos, XXIII jorns», AHCB, CC, Deliberacions, II-16, f..97v). Acerca de la figura de Pedro de Portugal y de su breve reinado (1464-1466) en el Principado, remitimos, a partir de ahora, a J. CALMETTE, Louis XI, pp. 236-264; Ernesto MARTÍNEZ FERRANDO, Pere de Portugal, rei dels catalans, vist a través dels registres de la seva Cancelleria, Barcelona, 1936; IDEM, Tragedia del insigne Condestable don Pedro de Portugal, Madrid, 1942; Luís ADAO FonsECA, O Condestável D. Pedro de Portugal, Porto, 1982; A. RYDER, The Wreck of Catalonia, pp.151-174.

${ }^{82}$ Una nave portuguesa había llegado -tal como recogía el dietario municipal de la época- el 14 de enero de 1464 a Barcelona, anticipando la posterior llegada del Condestable (Manual de Novells Ardits, vol. II, p. 443). En la reunión consistorial de ese día también se había determinado el envío de una comisión diplomática - aunque ignoramos si éste se hizo efectivo- para encontrarse con el nuevo rey antes de su entrada en la ciudad (AHCB, CC, Deliberacions, II-16, f. 85 r).

${ }^{83}$ J.M. SANS (ed.), Dietari o Llibre de Jornades, pp. 185-190. Descripción que, evidentemente, ha de complementarse con la que, de dicho acto ofrece el Llibre de les Solemnitats de Barcelona, vol. I, pp. 274-277. Puede encontrarse también alguna información añadida sobre la ceremonia en el registro de deliberaciones del Consulado de Mar de Barcelona (AHCB, Consolat de Mar, Deliberacions, I-1, f. 179r-v).
} 
que ha acabado por engullir el puente de madera construido para la ocasión junto a la Lonja ${ }^{84}$. Una barca permite al rey llegar a tierra firme y encontrarse con las autoridades y personalidades, no sólo de la ciudad, sino también del Principado, que esperan su desembarco. A partir de aquí, se inicia un desconocido desplazamiento -en este tipo de recepciones- que conduce directamente a Pedro de Portugal, a caballo, hasta la iglesia de Santa María del Mar, el segundo templo en importancia de Barcelona, tras la Seu, y muy próximo al litoral marítimo de la ciudad. Allí es recibido por el clero en procesión y, después de adorar la Vera Cruz, penetra en un recinto sagrado que aparece abarrotado de gente, inundado de luz y tomado por el sonido imponente de órganos y cantos religiosos. Luego, el monarca, siempre rodeado por un innumerable gentío que se distribuye por calles, tejados, puertas y ventanas, se dirige a los aposentos que le han sido lujosamente preparados en casa de Bernat de Gualbes, en la calle Ample, y, tras acceder a ellos, parece desaparecer por completo durante tres días, mientras la ciudad se ilumina en su honor y la población celebra su llegada con música, bailes y fuego.

Como si se tratara de un forzoso preámbulo impuesto por las circunstancias del momento -el largo viaje por mar, la azarosa climatología, las imposiciones de la guerra-, la inusual recepción inicial ofrecida a Pedro de Portugal parecía quedar desligada del resto de la ceremonia y, en cierta forma, venía a sustituir al tradicional encuentro extramuros entre el visitante y las autoridades municipales que solía preceder -como ya hemos podido ver a lo largo del presente trabajo- toda entrada real en Barcelona. En el mismo sentido, la aparente ocultación posterior del monarca podría tener algo que ver con una práctica -claramente perceptible en la entrada realizada, posteriormente, por el primogénito de Renato de Anjou, Juan de Calabria, en 1467por la cual el ritual período de espera del visitante en el exterior de las murallas de la ciudad -ahora poco aconsejable, dada la proximidad de la guerra- quedaba reemplazado por una discreta e inoperativa presencia en el interior del recinto urbano hasta el día elegido para la escenificación de la ceremonia. Discreción que, sin embargo, no excluía necesariamente la participación en el hipotético proceso negociador que pudiera establecerse acerca de los términos exactos en los que habría de desarrollarse la celebración $n^{85}$.

${ }^{84}$ La utilización de puentes honoríficos para las ceremonias de recepción que tenían lugar cuando el visitante llegaba por mar ya aparece bien documentada en Barcelona durante el siglo XIV. En 1355, Pedro el Ceremonioso y su esposa, la reina Leonor, habían entrado en la ciudad «per unum pontem factum in mari» (Crònica del Racional de la ciutat de Barcelona, «Recull de Documents i Estudis», I (1921), p. 125). En 1397, Martín el Humano había sido recibido de igual manera durante su primera visita como monarca: «et arripuit terram per pontem positum et factum de postibus et cohopertum de pannis de lana» (BC, Ms. 485, f. 271v).

${ }^{85} \mathrm{Nada}$ ha quedado recogido, sin embargo, en la documentación de la época acerca de la actividad de Pedro de Portugal en Barcelona entre el 21 y el 25 de enero de 1464 , ni de su contacto, durante esos días, con el gobierno de la ciudad. El domingo 22, los consellers habían solicitado de los representantes del estamento artesanal su disposición para participar en la fiesta que, con fecha aún por determinar, se pensaba ofrecer al nuevo rey (Llibre de les Solemnitats de Barcelona, vol. I, p 275). El martes 24 , el consistorio municipal había procedido a deliberar sobre algunos gastos motivados por la llegada del soberano, asi com también sobre el urgente 
No encontramos de nuevo a Pedro de Portugal hasta la tarde del 25 de enero, cuando, partiendo desde su alojamiento en la calle Ample, se dirige a caballo -siempre de la mano del escribano Safont- hacia el catafalco instalado en la cercana plaza de Framenors. Acompañado por algunos nobles - entre los cuales, el conde de Pallars- y sorteando al numeroso público que, de nuevo, se aglomera a su paso, el monarca llega hasta el engalanado estrado para, una vez en él, jurar respetar -sobre la Vera Cruz y un misal sostenido por el obispo de Vic- los privilegios y libertades que sus predecesores en el trono concedieron en el pasado a la ciudad de Barcelona ${ }^{86}$. Tras ello, abandona la escena sin más solemnidad y, por segunda vez, se refugia en sus aposentos en la casa de Benat de Gualbes.

$\mathrm{Ni}$ rastro, ese día, de la tradicional fiesta con la que la ciudad celebraba el juramento del soberano, puesto que ya había sido decidido que ésta, a diferencia de lo acostumbrado, tuviese lugar un día más tarde, y no inmediatamente después del trascendente acto mediante el cual quedaba sellado el compromiso de la monarquía con el municipio ${ }^{87}$. La ceremonia de la entrada real de Pedro de Portugal, cada vez más fragmentada, perdida toda su inmediatez, anulada gran parte de su intensidad escénica, tendía a adquirir, a medida que se prolongaba en el tiempo, un aire funcional que, tal vez, encajaba a la perfección con lo que se esperaba, por parte de los regidores barceloneses y de las autoridades del Principado, del nuevo rey ${ }^{88}$.

Finalmente, en la tarde del 26 de enero, vemos cómo Pedro de Portugal regresa al catafalco y, ahora sí, desfilan ante él los diferentes oficios

auxilio a la localidad de Cervera, asediada por las tropas de Juan II (AHCB, CC, Deliberacions, II-16, ff. 89v-90r) y, ese mismo día, una ordenanza pública anunciaba, por fín, los días 25 y 26 como aquellos en los que iba a hacerse realidad la esperada celebración (AHCB, CC, Ordinacions originals, XXVI-10, carpeta 663).

${ }^{86}$ Con la salvedad -según menciona Safont- de los que habían sido otorgados por Fernando I y Alfonso el Magnánimo, a los cuales, en tanto que miembros de la dinastía trastámara entronada en la Corona de Aragón desde el Compromiso de Caspe de 1412, no se les reconocía legitimidad alguna. En cualquier caso el nuevo monarca volvió a concederlos en ese mismo momento, ahora a título propio (J.M. SANS (ed.), Dietari o Llibre de Jornades, p. 187). Sospechamos -pero no es posible demostrarlo- que dicha cuestión biẹ pudo ser uno de los aspectos más tratados en los tres días que precedieron la ceremonia del juramento.

${ }^{87}$ En un registro de la serie de Clavaria -libros de carácter contable en los que se recogían los gastos e ingresos del erario municipal- del AHCB ha quedado constancia del documento en el que fue recogido dicho compromiso: «la carta de confirmació, per lo dit senyor rey a la dita ciutat feta, dels privilegis, usos e concesions de aquella, la qual carta és stada liurada a la dita ciutat francha de sagell, per gràcia que lo dit senyor ne ha feta a la dita ciutat» (AHCB, CC, Clavaria, XI-76, f. 85v. 1464, mayo, 11).

${ }^{88} \mathrm{El}$ motivo aducido para la escenificación por separado del juramento del monarca y de la fiesta en su honor tenía que ver, aparentemente, con la elección del cargo de batlle de la ciudad. La designación de este oficial real -junto al veguer, el máximo representante de la jurisdicción del soberano en el municipio-, se realizaba, cada tres años, el 25 de enero, a partir de una terna pressentada al rey por el propio consistorio barcelonés. YY, efectivamente, ese mismo día, coincidiendo con el juramento de Pedro de Portugal, se había procedido a elegir, en la Casa de la Ciudad, a los tres candidatos para ocupar dicho puesto (AHCB, CC, Deliberacions, II-16, ff. 90v-92r). Según se recogía en la memoria oficial de la ceremonia de entrada, el juramento de Pedro de Portugal era condición previa imprescindible para poder intervenir en la designación de oficiales y çargos relacionados con la ciudad: «e açó fou fet per quant lo dit dia de sant Pạu se havian alegir tres persones de les quals lo dit senyor havia a pendre una en batle de aquesta ciutat, e no poguera sens haver fet primerament lo dit jurament; e per ço en lo dit dia se feu lo dit jurament, sens altre serimonia, com encare no fos preparade la festa la qual es acustumade fer» (Llibre de les Solemnitats de Barcelona, vol. I, p. 276). 
artesanales de Barcelona con sus estandartes, representaciones y bailes distintivos. Instalado bajo un lujoso dosel, el rey tiene ocasión de contemplar -y aquí Safont no escatima detalles en la descripción- el paso de marineros y barqueros, acompañados de esclavos con los rostros pintados que atruenan el aire con el sonido de sus timbales; de observar cómo un dragón va arrojando fuego para conseguir abrirse camino entre la multitud que asiste al espectáculo, y de ver una nave que, transportada sobre carros, lleva a San Elmo en su popa. Luego, carpinteros armados, herreros, ballesteros, curtidores junto a hombres salvajes, pintores y freneros escoltando la figura de un águila dorada que no deja de bailar, plateros luciendo sus más selectas joyas, y sastres, también armados, con halcones posados en sus manos, completan, junto a otros oficios, el resto de la parada artesanal ${ }^{89}$.

Así que el último oficio -aquél cuyo mayor prestigio dentro del estamento le concede el privilegio de cerrar el desfile- abandona la plaza de Framenors, donde ha tenido lugar la ceremonia, y emboca por la calle Ample, siguiendo al resto de la comitiva en dirección a la Seu, Pedro de Portugal desciende del catafalco, monta en su caballo y, precedido por el conde de Pallars -quien exhibe la espada real-, toma el mismo camino. El ritual, a lo largo de esta jornada, no difiere del modelo clásico que ya conocemos. El palio que cubre al monarca ${ }^{90}$, las autoridades de la ciudad que lo escoltan y guían su montura, el guarnecido itinerario que conduce hasta la Catedral, la procesión del clero que recibe al soberano y lo acompaña hasta el interior del templo, la liturgia que allí se desarrolla ${ }^{91}$, y el regreso final del soberano a su alojamiento, ya concluido el día ${ }^{92}$, son imágenes que podrían devolver al evento una sensación de normalidad ceremonial, si no fuera porque correspon-

${ }^{89} \mathrm{La}$ intensidad descriptiva de la que hace gala Jaume Safont contrasta con el tono oficial y algo rutinario con el que son desglosados este tipo de desfiles en el Llibre de les Solemnitats de Barcelona. Por el contrạio, posee menos precisión a la hora de determinar el orden exacto -reflejo de un estatus sociạl y político- ocupado por cada oficio participante en dicha celebración. Para un análisis comparativo del desfile artesanal ofrecido a Pedro de Portugal con los realizados en otras ceremonias de entrada real en la Barcelona del siglo XV, véase M. RAUFAST, " $E$ vingueren los officis e confraries ab llurs entremeses e balls", $\mathrm{pp}$. 675-681. Por lo que se refiere a los entremeses y representaciones utilizados durante dichos desfiles, se ha de señalar que muchos de ellos -como el águila o el dragón- también desempeñaban un papel importante en la procesión que, cada año, tenía lugar en la ciudad con motivo de la celebración del Corpus.

${ }^{90}$ Palio del cual, siguiendo la tradición, se apropiaron, una vez acabada la ceremonia, los servidores de Pedro Portugal, para ser recuperado posteriormente por el consistorio municipal, a cambio de una compensación económica: «en quitar e cobrar dels uxers e ministrers del senyor rey en Pere, vuy beneventuradament regnant, lo pali, cordons e bordons per la dita ciutat fets per rahó de la novella entrada del dit senyor rey, als quạls uxers e ministers les dites coses se pertanyan per anticha pràticha e consuetut de la dita ciutat» (AHCB, CC, Clavaria, XI-76, f. $67 \mathrm{v})$. La misma situación se había dado, por ejemplo, en 1460 , con motivo de la entrada del príncipe de Viana (AHCB, CC, Clavaria, XI-73, f. 98v).

${ }^{91}$ Tras la oración frente a un altar mayor deslumbrante de oro y plata, Pedro de Portugal había descendido hasta la cripta de Santa Eulalia para rendir visita al sepulcro del príncipe de Viana. De la preparación del recinto sagrado para dicho acto ha quedado constancia en los registros de Sagristia de la propia Catedral (AСB, Sagristia, Llibre de Comptes, 1463-1465, f. 55r).

${ }^{92}$ Bajo la luz de numerosas antorchas que, igualmente, también habían servido para la recepción inicial del soberano en su llegada a la playa de la ciudad el 21 de enero. El consistorio pago, en esta ocasión, más de 60 libras por la compra de la cera necesaria para elaborar dichas antorchas (AHCB, CC, Clavaria, XI-76, f. 71v) 
den a la celebración de una entrada real, y ese día -tal como se encarga de remarcar Safont- las puertas de la ciudad permanecen todas cerradas ${ }^{93}$.

Lo que sigue tras la ceremonia es una historia de desencuentros y fracasos que colocará al Principado, a mediados de 1466, muy cerca de la derrota final frente a Juan II. Las divergencias entre el nuevo monarca y las instituciones catalanas, la incapacidad para encontrar apoyos en el complejo entramado diplomático europeo, las dificultades económicas para costear el conflicto, y la ausencia de éxitos remarcables en el campo de batalla, acabaron convirtiendo la ilusionante evocación de la figura del condottiero -según la terminología empleada por Vicens Vives ${ }^{94}$ - que partía inmediatamente hacia Cervera para enfrentarse al enemigo, en una apagada sombra, agonizando distante en las localidades de Vic y Manresa, cuya desaparición, el 29 de junio de 1466, concedía, paradójicamente, una nueva oportunidad a sus súbditos para prolongar la guerra ${ }^{95}$.

\section{1467-1471}

En agosto de 1466, Renato de Anjou aceptaba el urgente ofrecimiento de las autoridades catalanas y se convertía, para éstas, en el nuevo monarca de la Corona de Aragón. Su llegada al trono comportaba la intervención de Luis XI de Francia en favor del Principado y garantizaba, así, la posibilidad de equilibrar, como mínimo, el desarrollo del conflicto armado ${ }^{96}$. Sin embargo, el soberano nunca visitaría Cataluña, transformando su peculiar

${ }^{93}$ Véase nota 78.

${ }^{94}$ J. ViCEns ViVES, Juan II de Aragón, p. 292.

${ }^{95}$ En todo este tiempo, Pedro de Portugal tendría oportunidad de efectuar nuevas entradas en Barcelona, ahora ya sin la solemnidad de la primera. El 16 de marzo de 1464 , el monarca regresaba a la ciudad para jurar, días después, tos privilegios del Principado y recibir, a su vez, la prestación de fidelidad como nuevo senor de éste (Manual de Novells Ardits, vol. II, pp. 446447). En mayo de ese año, el consistorio municipal aprobaba la concesión del donativo -la habitual y costosa vajilla de plata- que había quedado pendiente de entregar al soberano con motivo de su entrada inaugural (AHCB, CC, Deliberacions, II-16, f. 115v). Finalmente, en agosto de 1465. Pedro de Portugal era recibido hasta en dos ocasiones diferentes por los consellers barceloneses en los aledaños de la ciudad. Un pago por el alquiler de monturas para dichas recepciones así lo corrobora: «per loguer de IIII bèsties en los quals, lo dit Johan Marqués e Johan Vilanova, vergués, cavalcaren, acompanyant los dits honorables consellers los dos jorns que lo senyor rey intră en la present ciutat» (AHCB, CC, Correu i menut, XX-1, f. 109v).

${ }^{96} \mathrm{La}$ nueva apuesta del Consell del Principat -organismo que, integrando a representantes de las diferentes instituciones y estamentos catalanes, conducía la politica del pais desde 1462intentaba claramente resolver los puntos débiles de su anterior elección. Frente a la imagen individual y solitaria de Pedro de Portugal, un retrato de familia con garantías de continuidad dinástica; ante la inferioridad bélica y el aislamiento internacional, la seguridad de la poderoșa contribución militar francesa; para solventar el desgaste y los efectos de la guerra, un territorio próximo capaz de abastecer al Principado. Así se había justifiçado la elección de Renato de Anjou ên una sesion del consistorio barcelonés celebrada el 30 de julio de 1466: "perquè la sua alteșa és virtuosíssima e té fill primogènit, home valerós, timorat, e de molta virtut e seny decorat, ja insignit de fill mascle de edat de XVIII anys o circa, molt bella creatura. E lo dit senyor rey té la terra, specialment Prohença, molt vehina a aquest Principat de Cathalunya, habitadora e farta de moltes coses, specialment de forments» (AHCB, CC, Deliberacions, IÎ-17, f. 118v). En cualquier caso -como ya se han encargado de remarcar la mayor parte de los historiadores-, esa aparente cercanía no escondía que, hasta ese momento, y por espacio de casi dos siglos, angevinos y catalanes habían sido enconados enemigos en el escenario político mediterraneo. Acerca del reinado de Renato de Anjou en Cataluña (1466-1472), remitimos, de nuevo, a las obras citadas en la nota 62 . 
reinado en una permanente y diplomática ausencia física -que, en cierta forma, aunque en un contexto muy diferente, podía hacer recordar la época napolitana de Alfonso el Magnánimo-, tan sólo compensada por la tardía llegada de su hijo y primogénito, Juan, duque de Calabria y de Lorena ${ }^{97}$.

Primero será Bofillo del Giudice, noble italiano al servicio de los Anjou, quien, tras cruzar los Pirineos al mando de una primera avanzada de socorro, entre en Barcelona el 22 de febrero de $1467^{98}$, y seis meses más tarde, en agosto de ese año, después de un largo e infructuoso asedio sobre Girona -bastión del bando realista en el norte del Principado-, el propio Juan de Calabria tendrá ocasión, por fin, de formalizar ceremonialmente, en tanto que primogénito al trono y lugarteniente general de Renato de Anjou, su encuentro con el municipio barcelonés. La celebración de su entrada dará lugar, una vez más, a una escenificación que, aún manteniéndose fiel a un modelo básico predeterminado, resultará diferente, por diversos motivos, de todo precedente conocido en la ciudad.

El 31 de agosto de 1467, una nutrida representación municipal, acompañada de numerosa gente armada, había recibido al primogénito en las proximidades de Barcelona. Descendiendo desde el norte del Principado, y tras hacer escala en Mataró y Badalona, Juan de Calabria se había encontrado, en el atardecer de dicho día, con las autoridades de la ciudad y los diputados de la Generalitat en las inmediaciones del Portal Nou -una de las principales vías de acceso a la ciudad, en el lado este de su perímetro- para, después de la protocolaria acogida, ser escoltado, por unos y otros, hasta el interior del recinto urbano. Apenas traspasado el umbral del mismo, sin embargo, la ceremonia había quedado bruscamente interrumpida y el primogénito había sido conducido hasta un alojamiento cercano, en la casa del tintorero Francesc Estaper, donde permanecería -reproduciendo, de alguna manera, lo sucedido con Pedro de Portugal en 1464- durante dos días, a la espera de que la celebración de su llegada se hiciese realmente efectiva ${ }^{99}$.

\footnotetext{
${ }^{97}$ En consonancia con todo ello, los iniciales mensajes que, desde el Principado, se habían hecho llegar a la corte de Renato, solicitando la visita de la familia real a Cataluña, habían dejado paso, finalmente, a las llamadas de auxilio en las que se reclamaba al monarca, ante todo, el envío de tropas con las que contener el avance del ejército realista. El 11 de diciembre de 1466, los consellers barceloneses se dirigían a la esposa de Renato de Anjou manifestando el deseo de poder contar con la presencia de la pareja real en el Principado: «exprimir, senyora molt excel·lent, no porien quanta és la affecció e devoció que, nosaltres e vostres fidelíssimos vassalls, han en la desijada e beneventurada venguda del dit senyor rey e vostra, de la qual supplicam li plàcia ésser migencera e supplicadora sia molt presta» (AHCB, CC, Lletres closes, VI-23, f. 89r-v). El 16 de febrero de 1467, las mismas autoridades municipales manifestaban su preocupación al soberano por el retraso en la llegada a Cataluña de las fuerzas francesas destinadas a intervenir ẹ el conflicto: «Lo rey Johạn, vehent que vostra alteșa no ns havia tramés soccors per poder-li resistir, ha haut ànimo de venir en los lochs circumvehins a aquesta vostra ciutat» (ibídem, f. 107r-v).

${ }^{98}$ Una ordenanza municipal publicada ese mismo día en Barcelona permite confirmar la existencia de una recepción -de tono marcadamente militar-por parte de la ciudad: «Ara hojats tothom, generalment, de part del molt magnífich mossèn Johan de Marimon, conseller, capità general de la ciutat de Barcelona, que tots los hòmens d'armes, ab lurs armes, cavalls e rossins, sien jus are, de present, a la plaça del Born, per exir al capità del senyor rey» (AHCB, CC, Ordinacions, IV-9, f. 86v).

${ }^{99}$ El dietario de Jaume Safont no presenta, en esta ocasión, el nivel de detalle del que hacía gala a la hora de describir la entrada real de Pedro de Portugal en Barcelona. Son los datos suministrados por el Llibre de les Solemnitats, por tanto, los que nos permiten aproximarnos, con una mayor nitidez, a la celebración de la visita de Juan de Calabria a la ciudad. En cualquier caso,
} 
El motivo de la repentina desaparición del ilustre visitante -que ya intuíamos en el caso de Pedro de Portugal- aparecía, ahora, claramente explicitado. Debido a la inseguridad del momento y a la creciente amenaza de un posible ataque enemigo, la expuesta espera ritual en el exterior de la ciudad quedaba sustituida por el seguro refugio en el interior de sus muros. A cambio, el primogénito perdía su imagen pública hasta que, tanto la forma como el contenido de la ceremonia de entrada real, quedasen verdaderamente configurados y concertados ${ }^{100}$.

En cualquier caso, todo ello no era sino el reflejo final y concluyente de un proceso preparatorio que se remontaba varios meses en el tiempo. Ante la llegada de las primeras noticias sobre el viaje del primogénito hacia el Principado, ya habían comenzado a activarse, desde Barcelona, los resortes destinados a evidenciar la capitalidad ceremonial y política del municipio ${ }^{101}$. El 6 de abril de 1467, el consistorio gestionaba la forma y el contenido de la celebración de la esperada entrada de Juan de Calabria en la ciudad ${ }^{102}$. El 12 de abril, tras conocerse la llegada del primogénito a Perpiñán, una primera embajada era enviada al encuentro de éste para establecer el marco de prioridades institucionales que exigían su presencia en Barcelona, con especial incidencia en la tradición que concedía a esta ciudad el privilegio de acoger el juramento del real visitante a su llegada a Cataluña ${ }^{103}$. Y a finales de ese

tal como sucedía en la entrada anterior, ambas obras resultan obligatoriamente complementarias: Llibre de les Solemnitats de Barcelona, vol. I, pp. 286-293; J. M. SANS (ed.), Dietari o Llibre de Jornades, pp. 209-210.

${ }^{100}$ «E com no fos custum que lo senyor rey o primogenit intra dins la ciutat, sens que dreta via no vage al cadeffal per fer lo jurament acostumat, los dits honorables consellers, per la necessitat e indisposició concorrent per causa de la guerra, volent metre lo dit senyor en repós e bona guarda, delliberaren metre lo dit senyor dịns la present ciutat, donant-li posada la casa d'en Ffrancesch Staper, tintorer, la qual es propinque al dit Portal Nou, e sobre lo Rech Comdal; la qual casa fou apparellada e mesa a punt com posada de senyor, e allí lo dit senyor sech lo dilluns e lo dimarts apres següent, en los quals dies los dits honorables consellers feren preparar les coses necessaries a la dita festa... e aximatex, per los dits honorables consellers los dits dies lo dit senyor primogenit fou visitat en la dita casa, de la qual no axí fins la jornada del jurament fahedor en lo cadeffal» (Llibre de les Solemnitats de Barcelona, vol. I, pp. 287-288). Aún así, la población de Barcelona había sido llamaada el mismo 31 de agosto, a celebrar la llegada de Juan de Calabria mediante el cese de la actividad laboral por la tarde y las clásicas iluminaciones nocturnas (AHCB, CC, Ordinacions, IV-9, f. 105r).

${ }^{101}$ Una capitalidad, por otra parte, ampliamente asumida en el conjunto del territọio catalán, pero que, desde el inicio de la guerra y, en especial, debido a la evolución del propio conflicto, había adquirido una dimensión mucho más trascendente. Centro político del Principado, las sucesivas victorias de Juan II en el terreno militar habían convertido a Barcelona en el único -aunque aún poderoso- antagonista real del depuesto monarca. De hecho, en 1467, la zona de influencia del Consell del Principat había quedado constreñida a un área, càda vez más reducida, que pivotaba alrededor de la propia Barcelona, y que dejaba fuera ciudades tan importantes como Lleida, Tarragona y Girona.

${ }_{102}{ }_{\text {} S}$ Sobre la felicíssima entrada e forma del jurament prestador per lo dit il-lustríssimo primogènit, lo dit Concell deliberà e conclós ésser remès als honorablẹs consellers e VIII persones del present Concell, los quals, ensemps ab los dits advocats ordinaris de la dita ciutat, e encara $\mathrm{ab}$ persones antigues e experimentades, vegen e regoneguen la forma del dit jurament prestador, a tota observacio de libertats e privilegis de la dita ciutat, e encare vegen e regoneguen la festa que serà feta al dit senyor primogènit en la beneventurada entrada» (AHCB, CC, Deliberacions, Il-18, f. 3r).

${ }^{103}$ El 10 de abril de 1467 , ante la noticia de la entrada de Juan de Calabria en Perpiñán, «en la qual molt honorosament és stat receptat», los consellers invitaban a los habitantes de Barcelona a realizar las clásicas iluminaciones nocturnas «per demostració de tanta alegria com haver se déu de la felicíssima venguda del dit senyor primogenit» (AHCB, CC, Ordinacions, IV-9, f. 90v). El 13 de ese mes, los regidores barceloneses expresaban, mediante instrucciones precisas a sus 
mismo mes, el 30 de abril, las autoridades municipales disponían que fuera la plaza del Born -y no la de Framenors, como era lo habitual- el escenario central de la prevista ceremonia, destacando su idoneidad espacial, su mayor proximidad al portal por el cual el visitante realizaría su ingreso en la ciudad, y certificando, al mismo tiempo, la nula incidencia que esta modificación podía tener en el aspecto jurídico del evento ${ }^{104}$.

Luego, las diferentes disposiciones tomadas y su correspondiente negociación -mientras Juan de Calabria seguía demorando su desplazamiento hasta Barcelona y persistía, estérilmente, en su intento de arrebatar Girona al bando realista- se habían prolongado, esporádicas y discontinuas, desde mayo hasta agosto de $1467^{105}$. Por último, el 27 de este postrero mes, el primogénito había anunciado su inminente llegada a la ciudad ${ }^{106}$, y, días después, el 31 de agosto, entre los inquietantes rumores que situaban al enemigo tan cerca de Barcelona como para hacerse sentir en el transcurso de la ceremonia de recepción, había entrado, finalmente, en ella ${ }^{107}$.

embajadores ante el primogénito, su negativa a que éste pudiese efectuar el acto de juramento en otro lugar que no fuera la propia Barcelona, dado que ello repercutiría inmediatamente en el privilegio que la ciudad, a este respecto, poseía: «crehents que, fahent-se lo dit jurament en altra part, seria dada dilació a la sua beneventurada venguda, e, si-us seria respost que, ab salvetat, la dita ciutat passàs per aquesta vegada en la prestacio del dit jurament, direu que tal salvetat seria total destrucció del dit privilegi, usus e pràtiques en açò observades, e, fahent-se aquest forat, los qui aprés vindrien volrien usar de la dita salvetat, e axí fareu punt ferm ẹ aço, no poder-se comportar que lo dit jurament sia prestat en altra part, sino en aquesta ciutat» (AHCB, CC, Lletres closes, VI-23, f. 122r-v). Con posterioridad, el 22 de mayo de 1467, una copia del juramento realizado por Pedro de Portugal, en su entrada en la ciudad en 1464, había sido enviada al embajador de la misma para que la utilizara como prueba fehaciente ante Juan de Calabria (ibídem, f. 137r).

${ }^{104}$ «Sobre lo jụrament fahedor per lo il·lustríssimo senyor primogènit, per quant en acò no concorre privilegi que los reys, en lurs novel·les entrades, sien tenguts jurar en lo Pla de Framenors, attés que lo dit primogènit ve de part de sol ixent, e la sua entrada és més dessent ésser feta per lo Portal Nou, per no haver fer tant circuit de anar al Portal de Sant Antoni, lo dit Concell del-liberà e conclós que lo dit senyor primogènit entre per lo dit Portal Nou e vingue jurar a la plaçe del Born, la qual plaçe és molt spaciosa e pertinent esser feta en aquella» (AHCB, CC, Deliberacions, II-18, f. 10r).

${ }^{105} \mathrm{~A}$ mediados de junio de 1467 , por ejemplo, los consellers barceloneses se dirigían a su embajador ante Juan de Calabria para, entre otras cosas, señalar la imposibilidad material de concentrar, en una misma jornada, la fiesta de recepción ofrecida al primogénito y la posterior ceremonia mediante la cual éste había de recibir, en nombre del rey Renato, la prestación de fidelidad por parte de sus nuevos súbditos: «lo qual jurament de fidelitat és acustumat d'ésser prestat a la gran sala del Palau Real, lo qual se preste alguns dies aprés de la entrada, segons tenits ja en memorial, car lo die de la felicíssima entrada del dit senyor tal jurament de fidelitat lo dit senyor acceptar no pot, com sia de molt occupat, axí per lo jurament que lo dit senyor ha a prestar, quant per festa d'entremesos, balls e de molta alegria que feta li serà» (AHCB, CC, Lletres closes, VI-23, ff. 146v-147r. 1467, junio, 15).

${ }^{106} \mathrm{AHCB}, \mathrm{CC}$, Lletres reials originals, IXA-4, carta 1135. El documento aparece transcrito en Llibre de les Solemnitats de Barcelona, vol. I, p. 286.

${ }^{107} \mathrm{El} 30$ de agosto, desde Mataró, el propio Juan de Calabria había solicitado a los consellers el envío de un destacamento armado con el que reforzar su no excesivamente numerosa escolta en la última fase de su viaje hacia Barcelona (AHCB, CC, Lletres reials originals. IXA-4, carta 1136). Un día antes, el 29 de agosto, los regidores municipales habían decidido reclamar la contribución del estamento artesanal de la ciudad para organizar un cuerpo armado con el que garantizar la seguridad del primogénito -y de ellos mismos-durante el encuentro institucional que había de desarrollarse fuera de las murallas: «E les dites cofraries, co es, cascuna d'elles, oferí als dits honorables consellers hun gran nombre de gent armada, qui la jornada de la dita entrada foren prests e aperellats de axir fora la dita ciutat, per rebre lo dit senyor primogenit, acompanyant aquell ensemps ab los dits honorables consellers dins la present ciutat» (Llibre de les Solemnitats de Barcelona, vol. I, p. 287). 
A la fragmentada apariencia que, en 1464, había tenido la celebración de la entrada de Pedro de Portugal, vinieron a añadirse, ahora, variaciones tan notables que parecían -ya fuera por la forzada adecuación a las circunstancias del momento, ya se tratase de la expresión voluntaria de una realidad diferente- remodelar, en cierta forma, la ceremonia. El aspecto estrictamente geográfico de la misma, en este caso, podía tener, igualmente, un trasfondo político: la nueva dinastía ya no llegaba a Barcelona desde Castilla y Aragón, como los trastámaras, sino desde Francia, y por lógica, accedía a la ciudad por su lado este, en lugar de hacerlo por el oeste. La simple evidencia física comportaba, en ese sentido, un claro desplazamiento del centro gravitacional de la celebración, en la misma medida que la nueva apuesta dinástica lo era respecto a la existencia misma del Principado.

Así, en la mañana -y no pasado el mediodía, como era tradicionaldel 2 de septiembre de 1467, el primogénito recuperaba la visibilidad y, abandonando su estricta reclusión de dos días en casa del tintorero Francesc Estaper, hacía lo propio con la ciudad y, directamente, salía de ella por el mismo portal por el que había entrado el 31 de agosto. A continuación, y como si nada de lo anterior hubiera sucedido, recorría el perímetro exterior de la muralla en dirección al mar para, unos cientos de metros más allá, volver a entrar en Barcelona, ahora con total solemnidad y acompañado de su distinguido séquito, por el Portal de Sant Daniel ${ }^{108}$.

Poco después, los presentes en la cercana plaza del Born habían visto como Juan de Calabria, tras ser recibido por los consellers y ascender los quince escalones del catafalco representativo allí construido, había jurado respetar los privilegios y libertades de Barcelona ante la Vera Cruz traída desde la iglesia de Santa María del Mar -en lugar de desde la Catedral, como siempre había ocurrido ${ }^{109}$. Formalizado el contrato jurídico, y mientras el

${ }^{108}$ Una ordenanza municipal del 28 de agosto, en la que se resumía el conjunto de la celebración, ya parecía preveer dicha circunstancia: "com lo ịllustríssimo senyor primogènit, lo die que entrerà per jurar, entrerà per lo Portal de Sanct Daniel, fahent la via de Sancta Marta e del Pla d'en Lull, e vendrà a jurar en la plaça del Born, en lo cadeffal aquí fet. E, prestant lo dit jurament, cavalcarà e tirerà la via dels Cambis, del carrer Ample, del Regomir, tot dre fins a la Seu, e aquí, feta oració, irà posar al Palau Real Major» (AHCB, CC, Ordinacions, IV-9, f. 104v). El sorprendente ritual no hacía, de hecho, más que zanjar -simbólica y literalmente- el dilema creado por la presencia del primogénito en el interior de la ciudad "antes" de haber realizado su entrada en ella. Pueden encontrarse resoluciones similares de dicha "problemática", aunque en relación a las entradas de prelados en las ciudades de la Francia bajomedieval, en Véronique JULEROT, La première entrée de l'évêque: réflexions sur son origine, «Revue Historique», 639 (2006), pp. 648-650.

${ }^{109}$ El contenido de dicho jưramento -sospechamos de nuevo (véáse nota 86)- debió volver a ser objeto de debate y discusión durante el tiempo que el primogénito pasó en su provisional alojamiento junto al Portal Nou. Por un lado, se obviaba en él de nuevo -aunque con mayor sutilidad que en tiempos de Pedro de Portugal- a los reyes de la dinastía trastámara: «totes libertats, constitucions, privilegis, consescions e gracies fetes e atorgades a la dita ciutat, ciutadans e habitadors de aquella, per los illustrissimos princeps e reys Jaume primer, Pere segon, Alfonso segon, Jacme segon, Alfonso tercs, Pere terçs, Johan primer, Martí primer, e altres qui aprés d'els hac succehit e loctinents lurs» (Llibre de les Solemnitats de Barcelona, vol. I, p. 290). Por otro, el hecho de que fuera el heredero de la Corona, y no el propio rey Renato de Anjou, quien realizara dicho juramento, obligaba a la ciudad a añadir, de inmediato, una cédula de protesta al documento oficial para evitar que la puntual práctica pudiera crear précedente de cara al futuro: «que per lo present acte no puga esser derogat ne fet algun prejudici tacitament o expresse, directament o indirecta, o en attre qualsevol manera a las constitucions, privilegis, libertats, consuetuds, us e práticha, ans aquels romanguen salves e illeses» (ibídem, p. 291). 
primogénito tomaba asiento en la lujosa silla destinada a su persona, los oficios artesanos de la ciudad habían iniciado su tradicional desfile en honor del visitante, exhibiendo sus enseñas, bailes y representaciones característicos en un escenario inhabitual, entoldado en su totalidad, y en el cual había quedado prohibida toda actividad que pudiera despertar confusión sobre el seguro desarrollo del evento ${ }^{110}$.

Por un itinerario igualmente inusual, a traves del cual se describía un dibujo inverso en el mapa urbano de la ciudad con respecto al trazado habitual de este tipo de ceremonias, la comitiva se había dirigido, posteriormente, hacia la Catedral ${ }^{111}$. Las calles Ample y del Regomir habían sido recorridas, así, por los oficios y sus entremeses, anunciando el paso de un Juan de Calabria que, precedido por la espada real ${ }^{112}$, cabalgaba bajo palio y aparecía rodeado, en todo momento, por las autoridades y representantes estamentales de la ciudad. Palio que, por lo que parece, ya nunca había abandonado del todo al primogénito, puesto que, al acabar la tradicional visita a la Seu, había seguido figurando -de nuevo, de la mano de los propios consellers- sobre la cabeza de éste durante el breve desplazamiento que lo había llevado hasta su alojamiento definitivo ${ }^{113}$.

${ }^{110}$ Así quedaba dispuesto en una ordenanza municipal publicada el mismo 2 de septiembre: «que no sia lícit ne permés a persona alguna, de qualsevol ley, stament, grau o condició sien, star a cavall en la plaça del Born la hora que lo jurament se presterà per lo il lustríssimo senyor primogènit e los entremeses se faran, ne poder lençar o tirar foc gresch ne cohets en la dita plaça, ne encare en alguna part de les encontrades hon lo dit senyor primogènit passarà (AHCB, CC, Ordinacions, IV-9, f. 106r).

${ }^{111}$ En realidad, la suma de ambos trazados -como si se tratase de las dos mitades de una misma cosa- venía, prácticamente, a coincidir con el recorrido de la procesión del Corpus en la Barcelona del siglo XV, esto es, básicamente: calle de la Bòria, calle de Montcada, plaza del Born, calle Ample y calle del Regomir. Esta última parte del itinerario implicaba -casualmente o no- que la procesión del Corpus -y, en este caso, también Juan de Calabria- habían de pasar, por fuerza, ante la sede del consistorio municipal -la Casa de la Ciutat-, con lo que ello pudiera tener de distinción y homenaje para dicha institución.

${ }^{112}$ Espada que, muy probablemente, era la misma que había sido utilizada por el rey Pedro de Portugal en su entrada en la ciudad en 1464. El 27 de abril de 1467, y a solicitud del propio Juan de Calabria, el consitorio barcelonés habia aprobado la entrega a éste de dicha espada (AHCB, CC, Deliberacions, II-18, f. 8v). Igualmente, el 30 de ese mismo mes, quedaba registrado el coste de la restauración y embellecimiento del -suponemos- mencionado emblema: «en pagar lo gorniment de la spasa feta per servey del senyor primogènit» (AHCB, CC, Clavaria, XI-81, f. 100v).

${ }^{113}$ Una novedad, esta última, de la cual no parecía encontrarse precedente alguno en la memoria ceremonial de la ciudad: «e los honorables consellers tornaren pendre los bordons e lo pali, e jus lo dit pali, lo dit senyor, axint de la Seu, acompanyat ab lo dit pali, anà al palau reyal, e descavalcant, muntà alt, acompanyat dels honorables consellers. Però es ver, que dels pessats se tench prática que pus erent intrats en la Seu, allí.s jequia lo pali, e sens pali anaven de la Seu fins al palau» (Llibre de les Solemnitats de Barcelona, vol. I, p. 293). La práctica, sin embargo, sí aparece documentada en el ceremonial francés, así como, muy concretamente, en el ritual de entrada solemne de la Provenza bajomedieval, donde el palio acompañaba al visitante hasta su alojamiento una vez concluida la ceremonia. Ha de entenderse, por tanto, que su aplicación en Barcelona, en esta ocasión, tenía mucho que ver con la procedencia de Juan de Calabria, ya fuera por deferencia hacia su persona por parte de las autoridades de la ciudad, ya fuera por exigencia del propio primogénito. Véanse, para la constatación de esta costumbre en la Francia de los siglos XIV y XV, Bernard GUENÉE; Françoise LEHOUX, Les entrées royales francaises de 1328 a 1515 , Paris, 1968; Noël COULET, Les entrées solennelles en Provence au XIV siècle, «Ethnologie Française», 7/1 (1977), p. 63-82. 
Acabada la ceremonia, instalado el primogénito en el Palacio Real ${ }^{114}$, las autoridades barcelonesas habían comenzado ya a ultimar la escenificación del acto de juramento de fidelidad al nuevo señor, mediante el cual se cerraba el acuerdo jurídico entre monarca y municipio ${ }^{115}$. Luego, se había de informar de todo ello al propio Renato de Anjou ${ }^{116}$. Más tarde, quedaba confirmar el donativo económico que, con motivo de su entrada solemne, la ciudad había de ofrecer a Juan de Calabria ${ }^{117}$.

El ciclo ceremonial dinástico iniciado con la entrada del primogénito, sin embargo, nunca quedaría cerrado. Ni Renato de Anjou ni su esposa, a pesar de sus promesas, se desplazaron jamás al Principado, y todo aquello que de novedad tuvo la solemnidad ofrecida a Juan de Calabria tan sólo pudo ser refrendado -si es que realmente así sucedió- tras el final del conflicto, con la dinastía trastámara de nuevo en el poder. Mientras tanto, la guerra siguió su curso, cada vez más internacionalizada, pero incapaz, al mismo tiempo, de llegar a un desenlace concluyente, y, en algunos momentos, mucho más condicionada por el juego diplomático que, en torno a ella, libraban Juan II y Luis XI en el escenario europeo, que por las operaciones militares llevadas a cabo en el campo de batalla ${ }^{118}$.

\footnotetext{
${ }^{114}$ Aunque, inicialmente, se había dispuesto que Juan de Calabria se instalase en el Palacio Episcopal, este se había negado a ello, y, el 22 de agosto, desde Hostalric, había reclamado ser alojado en el Palacio Real: «Entés havem nos féu metre a punt lo Palau del Bisbe de aquexa ciutat per nostra posada, lo que no és intenció nostra, e, perque del-liberam e volem posar en lo Palau Reial, per ço us pregam conmuteu vostra diligència e preparació en aquell» (AHCB, CC, Lletres reials originals, IXA-4, carta 1131). El Palacio Episcopal de Barcelona, sin embargo, ofrecía mucho mejores condiciones de alojamiento, frente al progresivo estado de deterioro del Palacio Real, y había sido residencia habitual de Juan II en sus visitas a la ciudad entre 1458 y 1461.

115 «lo dit Concell del-liberà e conclós ésser elects dotze síndichs, tres de quescum stament, per prestar al il-lustríssimo senyor primogènit, com a procurador de l'excel-lentíssimo senyor, lo senyor rey, la fidelitat en semblants entrades acustumades prestrar» (AHCB, CC, Deliberacions, II-18, f. 44r. 1467, septiembre, 3).

${ }^{116} \mathrm{El} 18$ de septiembre, los consellers notificaban al monarca el satisfactorio desarrollo de la entraḍa de su hijo en Barcelona, al tiempo que aprovechaban para insistir, una vez más, sobre la necesidad de su visita al Principado: «quant humílment podem, molt e molt, a vostra senyoria supplicam e, en gràcia, li demanam sia mercè sua la dita beneventurada venguda abreujar e anticipar quant pus prest porà. Lo il·lustríssimo senyor primogènit, caríssimo fill vostre, es en aquesta ciutat, en la qual és stat receptat ab aquella més honor que may sia stat receptat rey ne príncep de la Casa d'Aragó» (AHCB, CC, Lletres closes, VI-23, ff. 171v-172r).

${ }^{117}$ El propio Juan de Calabria se había apresurado a reclamar dicho donativo a su llegada a Barcelona, en un gesto que, probablemente, derivaba de su experiencia señorial en los territorios de la Casa de Anjou (vêase, sobre este aspecto, Michel HÉBERT, Dons et entrées solennelles au XVe siècle: Marguerite de Savoie (1434) et Jean d'Anjou (1443), «Provence Historique», 195-196 (1999), pp. 277-281). Finalmente, el 10 de octubre de 1467, el consistorio barcelonés había aprobado la fabricación de la tradicional vajilla de plata, siguiendo el modelo de aquéllas que, en el pasado, habían sido entregadas a anteriores primogénitos: «lo dit Concell del-liberà e conclós ésser fet, al senyor primogenit, semblant donatiu de vexella d'argent qual fou fet al senyor don Carles, de santa recordacio, e altres» (AHCB, CC, Deliberacions, II-18, f. 66r).

${ }^{118} \mathrm{El}$ apoyo de Luis XI a la causa del Principado nunca tuvo la continuidad ni el peso necesario para acabar de desequilibrar la balanza a su favor. En 1468, los propios conflictos internos del reino francés provocaron, incluso, que Juan de Calabria se ausentará durante casi un año de Cataluña, no regresando hasta mayo de 1469. En 1470, ante el progresivo distanciamiento del monarca francés, el primogénito se había visto obligado a viajar hasta Provenza para intentar obtener, sin aparente éxito, los recursos humanos y económicos que requería el mantenimiento de una guerra cada vez más difícil de ganar. A su regreso, el 2 de agosto de 1470 , las autoridades barcelonesas le habían ofrecido la protocolaria ceremonia de recepción institucional (AHCB, CC Correu $i$ menut, XX-1, f. 177v) y habían decretado que la ciudad celebrase su llegada con las correspondientes iluminaciones nocturnas (AHCB, CC, Ordinacions, IV-9, f. 156r).
} 
Ni siquiera la muerte de Juan de Calabria, en diciembre de 1470, provocó cambio alguno en la prudente postura de Renato de Anjou. Por el contrario, en lugar de Nicolás, hijo del fallecido $-\mathrm{y}$ legítimo continuador de la dinastía-, había sido Juan, el hijo bastardo de Juan de Calabria, el elegido para sustituir a éste en el Principado ${ }^{119}$. Su posterior llegada a Barcelona, el 12 de junio de 1471, sería la que provocaría la indignación del escribano Jaume Safont -tal como veíamos en el inicio de este apartado-, al contemplar cómo, contra toda costumbre, un bastardo era recibido formalmente por las autoridades de la ciudad y del Principado en el exterior del recinto amurallado ${ }^{120}$. En realidad, si nos atenemos a lo que todavía faltaba por llegar, una vez concluido el conflicto bélico, la verdad es que, en cuanto a sorpresas ceremoniales, Safont -permítasenos decirlo así- aún no lo había visto todo.

\section{CEREMONIAS PARA DESPUÉS DE UNA GUERRA}

(1472-1473)

Explica Peter Arnade, en uno de los pasajes más apasionantes de su estudio sobre el universo ceremonial de la ciudad de Gante en la Baja Edad Media, cómo, tras el fracaso final de la rebelión armada que, entre 1451 y 1453, había enfrentado al municipio con su señor, el duque de Borgoña, los líderes de la misma se habían visto obligados a escenificar su derrota a través de una humillante ceremonia de contrición. El 30 de julio de 1453, cumpliendo lo estipulado en el tratado de paz firmado con Felipe el Bueno, los dirigentes municipales de Gante habían salido a encontrarse con el duque y su séquito en las afueras de la ciudad, descalzos y vestidos con simples túnicas blancas, para arrodillarse ante el vencedor, reconociendo el error cometido e implorando su perdón. No contento con ello, Felipe el Bueno había exigido, además, el cierre perpetuo de uno de los portales de Gante que más se habían significado durante el conflicto, al tiempo que procedía a confiscar los estandartes representativos de la ciudad. Con dicha ceremonia -que podría ser entendida como una representación del poder y, en la misma medida, como

${ }^{119}$ Así lo comunicaba Renato de Anjou a los consellers barceloneses en una carta fechada el 5 de abril de 1471: «Nós trametem aquí, loctinent general, lo il·lustre don Joan de Calabria, fill natural de l'il·lustríssimo don Joan, primogènit nostre de inmortal memòria, per presidir en aqueys regne e terres, fins que nós o nostre primogènit hi siam, lo que havem sperança en Nostre Senyor Deu que serà en breu» (AHCB, CC, Cartas reials originals, IXA-4, carta 1173).

${ }^{120} \mathrm{~A}$ pesar de que Alan Ryder parece presentar el ingreso del bastardo Juan de Calabria en Barcelona como si éste hubiera tenido categoría de entrada solemne (A. RYDER, The Wreck of Catalonia, p. 207), la realidad es que nada, en las fuentes de la época, permite realizar tal aseveración. De lo único que ha quedado constancia - tal como estas mismạs fụentes señalan- es de la ya comentada recepción institucional extramuros, y del posterior alojamiento del visitante en el Palacio Real (J.M. SANS (dir.), Dietaris de la Generalitat, vol. I, p. 202; Manual de Novells Ardits, vol. II, p. 502; A HCB, CC, Correu i menut, XX-1, f. 186v). Sí que existió, sin embargo, un intenso debate acerca de las atribuciones que Renato de Anjou había concedido a su nieto como lugarteniente suyo en el Principado (AHCB, CC, Deliberacions, II-20, ff. 93r-107v). A causa de los reparos de las autoridades catalanas, el juramento de Juan de Calabria en Barcelona no había podido ser efectuado - una vez matizado el alcance de dichas atribuciones- hasta ocho días más tarde, el 20 de junio de 1467, en la Catedral de la ciudad (Manual de Novells Ardits, vol. II, p. 502). 
un ejemplo del poder de la representación ${ }^{121}-$, el duque de Borgoña, según interpreta Peter Arnade, recuperaba la imagen de autoridad que, desde la propia Gante, tanto se había cuestionado en los últimos años ${ }^{122}$.

La resolución escénica del conflicto entre la ciudad de Gante y el duque de Borgoña queda bien lejos -y es precisamente a causa de ello, dado su marcado contraste, que nos ha interesado reseñarla aquí- de lo sucedido, en 1472, con motivo de la capitulación firmada entre la ciudad de Barcelona y Juan II, tras el año de asedio con el que el monarca había certificado su victoria final en la Guerra Civil Catalana ${ }^{123}$. En clara concordancia con los términos contenidos en el pacto firmado entre ambas partes, la puesta en escena del regreso del soberano a la ciudad, después de más de diez años de forzada ausencia, no parecía pretender pasar cuentas con aquellos que habían provocado esta última circunstancia, ni tampoco servir como catarsis dramática destinada a devolver a la figura del rey, en un solo acto, el prestigio durante tanto tiempo negado. En su lugar, la entrada de Juan II en Barcelona, el 17 de octubre de 1472, lo que pareció querer borrar fue, precisamente, esa misma negación, ese largo rechazo, prevaleciendo en ella -por encima del recuerdo de la confrontación, también presente- la búsqueda de un reencuentro ceremonial que permitiese, evocando un pasado anterior a la guerra, escenificar la ficción pactada de una continuidad política que, en la realidad, y como era obvio, nunca había existido. De esa forma, si -según parecía sugerir el texto de la Capitulación de Pedralbes en su primera cláusula ${ }^{124}$ - no había existido rebelión ni tampoco rebeldes, nada obligaba, por tanto, a que el regreso del monarca a Barcelona hubiese de ser, forzosamente, ni reparador ni iniciático. En ese sentido, dicha entrada fue, más bien, el primer acto de una obra mucho más elaborada que no habría de concluir hasta un año más tarde, cuando Juan II, tras su campaña contra la ocupación francesa del Rosellón, retornó a la ciudad en octubre de 1473 y fue acogido en ella con una distinción ceremonial que superaba, en mucho, la que pudiera haber recibido cualquier otro soberano durante ese siglo en Barcelona.

Así, tras encontrarse con las autoridades de la ciudad en las proximidades de la misma, el soberano había entrado en Barcelona -en las primeras horas de la tarde de aquel 17 de octubre de 1472- por una abertura realizada

\footnotetext{
${ }^{121}$ Véase, sobre esta cuestión, G. BALANDIER, Le pouvoir sur scènes.

${ }^{122} \mathrm{P}$. ARNADE, Realms of Ritual, pp. 114-126.

${ }^{123}$ Tras un prolongado asedio que había llevado a la ciudad a una situación de precariedad alimenticia dificilmente sostenible por más tiempo, y ante la imposibilidad de conseguir e aprovisionamiento necesario, las autoridades barcelonesas habían accedido a negociar con el monarca el final del conflicto, al tiempo que procedían a retirar su fidelidad a Renato de Anjou El 16 de octubre de 1472 se firmaba, finalmente -en el monasterio que le daba nombre, en el exterior de la ciudad-, la Capitulación de Pedralbes, en la cual, a grandes rasgos, Juan II se avenía, no sólo a mantener ințactos los privilegios y libertades de Barcelona y del Principado, sino también a no condenar -ni represaliar- la actitud de las instituciones catalanas desde su levantamiento en 1462. El texto del documento aparece reproducido en Manual de Novells Ardits, vol. II, pp. 554-570. Para un análisis del contenıdo de dicha Capitulación véase S. SOBREQUÉS; J. SOBREQUES, La guerra civil catalana del segle XV, vol. II, pp. 333-354.

${ }^{124}$ «que placia a vostra $M^{\text {at }}$ decernir e declarar los dits actes no esser stats preiudicials, o derogants en alguna manera a la fidelitat ans los poblats en dita ciutat e principat esser haguts per bons leyals e feels» (Manual de Novells Ardits, vol. II, p. 555).
} 
en el baluarte que había defendido el portal de Sant Antoni durante el asedio, para, a continuación, recorrer el amplio itinerario urbano que, a través de la calle del Hospital, la Rambla, la calle Ample, la plaza del Born, la calle de Montcada, la calle de la Bòria y la plaza de Sant Jaume, llevaba hasta la Catedral. Recibido por el clero en procesión, Juan II había entrado en el templo y, tras el acostumbrado ritual, se había dirigido, finalmente, a su alojamiento en el Palacio Real ${ }^{125}$.

En su estructura básica, se trataba de una sencilla ceremonia que tendía a identificar dicha entrada con aquéllas que carecían del grado de solemnidad privativo de las primeras ocasiones, diferenciándola, justamente, de la que el propio monarca había realizado en 1458 (la entrada por el portal de Sant Antoni, en lugar de por el de las Drassanes, y la ausencia del catafalco honorífico y del desfile de los oficios artesanos, serían los rasgos que podríamos considerar más llamativos) ${ }^{126}$. Supeditando jerárquicamente la entrada de 1472 a la efectuada en 1458 -pero ello es tan sólo una posible interpretación-, se escenificaba una lógica continuidad ceremonial con la que poder suavizar la realidad de una gran fractura política.

Sobre dicha estructura conciliadora vinieron a incorporarse, sin embargo, signos que traducían con mayor literalidad el momento histórico. Por un lado, el reconocimiento a las fuerzas sitiadoras por parte de Juan II había tenido lugar, primero, mediante los actos de nombramiento de caballeros que el rey había ido escenificando, durante la propia entrada, tanto en el monasterio de Valldonzella como en el interior del ahora ya inservible baluarte del portal de Sant Antoni, y luego, un día más tarde, a través del desfile que las naves de la armada realista habían efectuado, en presencia del soberano y de las autoridades municipales, frente a la playa de Barcelona ${ }^{127}$. Por otro, la debilidad del municipio, tras el desgaste de los años de guerra y las privaciones del asedio final, no podía quedar al margen de la propia celebración, de tal manera que, en la ordenanza pública en la que, el mismo

${ }^{125}$ Las fuentes de la época son relativamente parcas a la hora de suministrar información precisa sobre la ceremonia de reingreso de Juan II en Barcelona en 1472. Es el dietario consistorial barcelonés, en esta oportunidad, el que permite visualizar -sólo hasta cierto puntolo ocurrido durante dicho evento (ibídem, pp. 508-509). Frente a ello, el dietario de la Generalitat apenas dedica un par de líneas de compromiso a la noticia: «Aquest die entrà en la ciutat de Barchinona, ab gran gala e triunpho, lo excellentíssimo senyor lo senyor rey don Johan» (Dietaris de la Generalitat, vol. I, p. 210).

${ }^{126} \mathrm{El}$ itinerario utilizado en 1472 era el mismo que había seguido el propio Juan II en 1454 con motivo de su entrada en Barcelona como lugarteniente general en Cataluña del entonces monarca, Alfonso el Magnánimo, o, sin ir más lejos, el que había recorrido el príncipe de Viana, en su segunda entrada en la ciudad, en 1461.

${ }^{127}$ El 18 de octubre, situados junto al edificio de la Lonja, Juan II y los consellers, así como un numeroso séquito real, habían contemplado el paso ostentoso -estandartes alzados, artillería en funcionamiento- de aquellas naves que, bloqueando el acceso a la playa de Barcelona, habían contribuido decisivamente al triunfo del asedio sobre la ciudad. Luego, el rey había subido a la galera insigna de la flota y había nombrado caballero al capitán de la misma (Manual de Novells Ardits, vol. II, p. 509). 
17 de octubre de 1472, se anunciaba la entrada de Juan II en la ciudad, quedaba evidenciada, al mismo tiempo, la delicada situación de la misma ${ }^{128}$. Luego, mientras las clásicas iluminaciones festivas -siempre presentes en este tipo de eventos- se prolongaban noche tras noche, fusionando la llegada del rey con el regreso de la paz, Juan II había recibido el juramento de fidelidad por parte de los representantes de la ciudad de Barcelona y, apenas transcurridos dos meses, había partido hacia un Rosellón dominado por las tropas de Luis XI para recomponer las adversas consecuencias del tratado que él mismo -con el fin de disponer de efectivos militares con los que hacer frente al levantamiento en armas del Principado- había firmado con el monarca francés en $1462^{129}$.

Con dicho gesto, se operaba un rápido desplazamiento escénico en el cual confluían y se asociaban, potencialmente, hasta tres objetivos distintos: la recuperación material -aprovechando los recursos inmediatos que ofrecía la existencia de un ejército ya organizado- de los condados del Rosellón y la Cerdaña ${ }^{130}$; la desactivación, simbólica y real, de la intervención francesa -léase Luis XI o Renato de Anjou- en Cataluña; y la canalización efectiva -derivando el conflicto hacia un enemigo exterior- de los mecanismos -emocionales, económicos, militares- que agilizaban la nueva adhesión del conjunto del Principado a la figura de su soberano.

${ }^{128}$ «ab tenor de la present pública crida preguen los dits honorables consellers a tothom, generalment, que, la present jornada, cascú en ses cases, botigues e obredors ces de fer lo exercici de son offici, festivant la beneventurada entrada de la magestat del sereníssimo e virtuossíssimo senyor, lo senyor rey don Johan, beneventuradament regnant, lo qual, per se gran virtut, humanitat e clemencia, ha atorgat $\mathrm{e}$ porte a la present ciutat lo dit benifici de pau... Preguen, més avant, los dits honorables consellers, a tots aquells ciutedans, poblats e habitadors de la dita ciutat qui tinguen ffarines, que la present jornada lus plàcie pastar al pes degut per vendre pa a tothom qui'n vulle» (AHCB, CC, Ordinacions originals, XXVI-3, carpeta 908). Jaume Safont, en su escueta referencia sobre la entrada de Juan II, también incidía en dicha circunstancia: «aprés dinar, lo senyor rey en Johan Segon d'Aragó entrà en la ciutat de Barchinona, la qual havia tenguda asetjada contínuament per mar e per terra per spay d'un any e III dies; e érem venguts a manjar pa de faves mesclades ab mastall. E havia prou dies en la setmana que no's trobava pa de alguna ley per les places» (J. M. SANS (ed.), Dietari o Llibre de Jornades, p. 237).

${ }^{129} \mathrm{El}$ juramento de fidelidad -requisito obligado tras los reinados de Enrique IV, Pedro de Portugal y Renato de Anjou en el Principado- tuvo lugar el 22 de octubre de 1472 en el Palacio Real de Barcelona (Manual de Novells Ardits, vol, II, p. 510). El 25 de dicho mes, las autoridades barcelonesas aún seguían solicitando a la población de la ciudad que continuara celebrando el final del conflicto (AHCB, CC, Ordinacions, IV-10, f. 27r-v). Finalmente, el 29 de diciembre de 1472, Juan II había abandonado Barcelona para dirigirse hacia Perpiñán (Manual de Novells Ardits, vol. II, p. 511).

${ }^{130}$ Por el tratado de Bayona, Juan II había aceptado ofrecer a Luis XI, en 1462, los condados del Rosellón y la Cerdaña como garantía del pago de la deuda contraída con dicho monarca por la ayuda militar francesa en el inicio de la Guerra Civil Catalana. Posteriormente, en 1463, Luis XI había anexionado, unilateralmente, ambos condados a Francia, basándose en el vacío de poder creado tras el nombramiento de Enrique IV como señor del Principado. Acerca de esta cuestión, véase J. CALMETTE, Louis XI, pp. 67-92. 
Así, actos políticos ${ }^{131}$, procesiones $^{132}$, llamamientos a las $\operatorname{armas}^{133} \mathrm{e}$, incluso, ceremonias de entrada ${ }^{134}$ tendieron a girar, en este período, alrededor del inicio, y posterior evolución, de la campaña del Rosellón, y con ello, Barcelona pasó, sin solución de continuidad, de celebrar las desgracias de Juan II a congraciarse por sus victorias que, ahora, eran también las del Principado ${ }^{135}$.

A su regreso de dicha campaña -tras la firma de un tratado de paz con Luis XI que, sin embargo, lejos de solucionar el conflicto, tan sólo se limitaba a postergar su incierto desenlace-, revestido de un aura heroica hábilmente promocionada, convertido en triunfador frente a los enemigos del Principado -en una imagen que pretendía borrar aquella otra, todavía muy reciente, que podía identificarlo a él mismo como el enemigo que había triunfado sobre el propio Principado-, Juan II pudo, por fin, asumir el papel que la entrada de 1472 en Barcelona -por los posibles motivos que ya hemos tenido ocasión de valorar- le había impedido representar.

Antes de ello, sería el primogénito Fernando quien, tras su decisiva contribución al fracaso del asedio francés sobre Perpiñán, tendría ocasión de

\footnotetext{
${ }^{131}$ Tras su exitosa entrada en Perpiñán, Juan II había convocado, a finales de febrero de 1473, Cortes generales en dicha ciudad, al tiempo que dirigía los preparativos de defensa destinados a protegerla del inminente contraataque francés (ibídem, pp. 362-364).

${ }^{132} \mathrm{El} 5$ de febrero de 1473 , Barcelona había celebrado con una procesión la llegada de la noticia de la entrada de Juan II en Perpiñán (Manual de Novells Ardits, vol. II, p. 512). El 26 de septiembre de ese mismo año, otra procesión había conmemorado el tratado de paz firmado entre Juan II y. Luis XI, con el cual se cerraba -pero sólo temporalmente- el conflicto (AHCB, CC, Ordinacions originals, XXVI-4, carpeta 936).
}

${ }^{133}$ El 5 de abril de 1473 , Juan II requería públicamente de los habitantes de Barcelona -en virtud del Princeps namque (véase nota 70)- su participación activa en la defensa de Perpiñán ante las tropas francesas de Luis XI: "fonch cridat lo princeps namque per totes les places e lochs públics de Barchinona en aquesta manera: que primer vẹnien dos trompetes a peu, e detrạs ells gran colp de saigs a peu portant sengles fayes de foch cridants a grans crits; "Via fora; princeps namque»; e detrac venia mossèn Johan Bernat Terré, regent la vegaria de Barchinona, a cavall, vestit d'una cota d' armes reyals» (J.M. SANS (ed.), Dietari o Llibre de Jornades, pp. 237-238).

${ }^{134} \mathrm{El} 31$ de mayo de 1473, el infante Fernando, tras 11 años de ausencia -después de su apresurada partida, junto a la reina, en 1462- regresaba a Barcelona, ahora como «rey de Sicília, príncep de Castella, primogènit e governador general d'Âragó». Al igual que había sucedido con su padre en octubre de 1472 , el inicial reencuentro volvió a carecer de la solemnidad atribuible a las entradas inaugurales de la monarquía. Por otra parte, el primogénito, que llegaba desde Castilla conduciendo tropas de refuerzo, apenas se detuvo unos días en la ciudad antes de partir hacia el Rosellón, el 4 de junio, en auxilio de Juan II. Así quedaba recogida dicha entrada -por lo demás, verdaderamente mimética de la realizada por Juan II en 1472- en el Dietario dẹ la Generalitat: "Aquest dia entrà en Barchinona, a les VI hores deprés dinar, lo excel-lentíssimo senyor don Fferrando... venint de Castella e d'Aragó. Entrà per lo portal de Sant Anthoni fins al portal de la Bocaria, e per la Rambla avall, e per lo Dormidor de Frares Menors passà per lo carrer Ampla e per los Cambis, e per lo carrer de Muncada fins a la capella d'en Marcús, e per la Bòria e a la plassa del Rey, e descavalcà a la Seu, qui bellament ere ornada, on féu oració, e aprés se'n muntà al palau reyal, en lo qual fa la sua residència» (Dietaris de la Generalitat, vol. I, p. 212).

${ }^{135}$ Hasta tres procesiones, en días consecutivos, habían sido celebradas en Barcelona, a finales de junio de 1473 , tras conocerse en la ciudad la victoria de Juan II sobre los sitiadores franceses en Perpiñán (AHCB , CC, Ordinacions originals, XXVI-4, carpeta 923). Como exacerbado contraste, retêngase la cruda y calculada interpretación que, en 1468 , en plena Guerra Civil Catalana, habían realizado los consellers de Barcelona de la muerte de la reina Juana y del estado de salud de Juan II y del infante Fernando: «per moltes vias som stats avisats com la reyna Johanna morí dissabte prop passat a les $\mathrm{V}$ hores, e lo digmenge següent la portaren a Poblet, e que lo rey Johan era malalt de mal de costat, e lo fill stave assats enfresquat. Totes aquestes coses són vias e carreres per les quals Nostre Senyor Déu prepare la endreça e benefici d'aquesta pàtria» (AHCB, CC, Lletres closes, VI-24, f. 2r. 1468, febrero, 17). 
realizar su ingreso solemne en Barcelona, el 20 de julio de 1473, a manera de anticipo dinástico de lo que sucedería, tres meses más tarde, con Juan II.

En la mañana del mencionado día ${ }^{136}$-como si se tratara de exorcizar ritualmente la presencia de los Anjou en la ciudad, apropiándose del espacio ceremonial que, una vez, Juan de Calabria había utilizado para acceder a ella-, Fernando entraba en Barcelona por el portal de Sant Daniel para dirigirse hasta la plaza del Born y contemplar -desde la ventana de una de las casas de dicha plaza, y no desde el catafalco habitual- el brillante desfile de entremeses, representaciones y oficios artesanos que la ciudad organizaba en su honor ${ }^{137}$. Luego, bajo palio, por un itinerario idéntico al utilizado en 1467 por el primogénito de Renato de Anjou -calles Ample y del Regomir, y plaza de Sant Jaume-, Fernando llegaba hasta la Catedral, oraba en su interior, y acababa alojándose en el Palacio Episcopal ${ }^{138}$.

La ceremonia, que recuperaba el aire inaugural de las grandes solemnidades $^{139}$, preparaba ya el terreno -tal como hemos apuntado- para la posterior llegada de un Juan II que, a principios de octubre de 1473, tras formalizar la tregua con Luis XI y trasladar la celebración de las Cortes de Perpiñán a Barcelona, iniciaba el viaje de regreso, por mar, hacia el Principado. Bordeando la costa, convalesciente aún de una reciente enfermedad -no hay que olvidar que, en junio de ese año, Juan II había alcanzado los 75 años de edad-, el monarca había fondeado en Roses y Blanes, antes de desembarcar en Badalona y dirigirse al monasterio de Sant Jeroni de la

\footnotetext{
${ }^{136}$ El propio Fernando había solicitado, ya en las cercanías de Barcelona, que la ceremonia de entrada se realizase por la mañana (AHCB, CC, Lletres reials originals, IXA-4, carta 1295. 1473, julio, 17. Sant Andreu).

${ }^{137}$ Así describía Jaume Safont lo sucedido en la plaza del Born en dicha entrada: «e trobà tot lo Born enpaliat de molts bells draps de ras e tot lo cel envalat de draps de colors perquè lo sol no $y$ entràs, e aquí ell descavalcà e muntà a casa d'en Pujades, e asech-se en una finestra, sperant la gran festa que li havien apperallada, e stant axí, començaren a passar molts castells ab moltes belles representacions. Aprés vengueren tots los oficis o gents de confraries, quascuns ab lur standart e quascuns venien ben abillats ab algun entramés que l'u no era semblant del altre» (J.M SANS (ed.), Dietari o Llibre de Jornades, p. 240) La imagen contrasta vivamente con la que el mismo Safont ofrecía en 1461, con motivo de la primera y discutida entrada de Fernando en la ciudad como primogénito (véase nota 56).

${ }^{138}$ El programa de la ceremonia ya había sido anticipado por el consistorio municipal a la población de Barcelona, mediante una ordenanza pública, el 15 de julio: «entrant per lo portal de Sant Daniel, e venint, sens serimònia, fins al Born, e aquí, stants los officis e confraries, venints quescuns ab lurs entremesos e alegries, li faran la deguda reverència, e discorreran, quescuns per son orde, la via de Sancta Maria de la Mar e, passants devant la sglèsia, tireran per lo carrer Ample e per lo Regomir amunt e, passant devant Sanct Jaume, vindran a la Seu, e, passants tots, e feta la dita reverencia al dit senyor, partirà se reyal persona, ab la serimònia del-liberada, e tirerà la mateixa via fins sie arribạt a la dita Seu» (AHCB, CC, Ordinacions, IV-10, f. 43r-v). Igualmente, otra ordenanza municipal, publicada el 19 de julio, prohibía taxativamente que nadie pudiese llevar armas o exhibirse a caballo en la plaza del Born durante el tiempo que durase la ceremonia (AHCB, CC, Ordinacions originals, XXVI-14, carpeta 930).

${ }^{139}$ No en vano, 10 días después, el 30 de julio de 1473, Fernando juraba respetar los privilegios y libertades del Principado, así como también el contenido de la Capitulación de Pedralbes, tras lo cual recibía el correspondiente juramento de fidelidad por parte de los representantes de la ciudad de Barcelona (J.M. SANS (ed.), Dietari o Llibre de Jornades, p. 241).
} 
Murtra, ya en las proximidades de Barcelona, para completar allí su total recuperación ${ }^{140}$.

El 16 de octubre, el consistorio barcelonés había comenzado a planificar la recepción al soberano ${ }^{141}$. Luego, las visitas de las autoridades municipales a Sant Jeroni de la Murtra y las consiguientes negociaciones con el monarca y su entorno habían acabado configurando un modelo de ceremonia que, siguiendo los pasos de la otorgada al primogénito en junio de ese año, iba mucho más allá y, por primera -y única- vez en la Barcelona del siglo XV, adoptaba el aspecto de una verdadera entrada triunfal. El 19 de octubre, en una sesión en la que se había procedido a ensalzar enfáticamente la figura de Juan II, destacando tanto su conducta heroica en Perpiñán en defensa del nombre y prestigio «de la Casa d'Aragó», como su humildad personal a la hora de no reclamar abiertamente distinción ceremonial por ello, los consellers habían planteado la posibilidad de que su entrada en Barcelona gozase, en esta ocasión, del privilegio -insólito, como ya hemos dicho, en la tradición de la ciudad- de ser realizada sobre una carroza triunfal ${ }^{142}$. El 23 de ese mismo mes, finalmente, el Consell de Cent aprobaba la forma de la recepción, así como el gasto que su puesta en escena había de suponer para las mermadas arcas municipales ${ }^{143}$.

${ }^{140}$ El 9 de octubre de 1473 , los consellers de Barcelona ponían en conocimiento del primogénito el paso de su padre por Roses y por Blanes, su inminente llegada a Badalona y la posibilidad de que el monarca prefiriese descansar, durante unos días, en el monasterio de Sant Jeroni de la Murtra antes de realizar su entrada en la ciudad (AHCB, CC, Lletres closes, VI-25, f. 109r). El 12 de octubre, Juan II desembarcaba en Badalona (Manual de Novells Ardits, vol. II, p. 517).

${ }^{141}$ Mediante la creación de una primera comisión consultiva, en la cual -sị no confundimos su identidad con la de otro hipotético notario del mismo nombre- figuraba, curiosamente, Jaume Safont (AHCB, CC, Deliberacions, II-21, f. 254r).

${ }^{142}$ En realidad, el monarca sí parecía haber sugerido, aunque cọn hábil diplomacia, tal posibilidad: «E jatsia se majestat no sia desijosa de coses pomposes e, interrogat en qual forma vol se gran altesa entrar, ço és, si vol li sia feta festa o no, ha respost ho remet tot a la ciutat, emperô, som hauts sentiments li plauria li fọs fet carreró triumphal» (AHCB, CC, Deliberacions, II-21, f. 254v). Desgraciadamente, los registros de deliberaciones del consistorio barcelonés en el período bajomedieval suelen limitarse a informar del tema debatido y de su resolución final, omitiendo los detalles del proceso de discusión que tan útiles nos serían para poder valorar y determinar la adhesión o el rechazo que despertaba cada propuesta, así como el grado de unanimidad que respaldaba las decisiones tomadas en dichas sesiones.

${ }^{143}$ Ibídem , f. 259v. A dichos gastos venían a sumarse los realizados, apenas unos meses antes, con motivo de la entrada del primogénito, en lo que era un importante dispendio para una ciudad que tardaría aún años en recuperar su pulso económico habitual. Asimismo, Juan II había solicitado de la ciudad la concesión de un donativo económico para ayudar a paliar los gastos que la campaña del Rosellón había supuesto para el tesoro real (Ibídem, f. 258r). 
En consecuencia, el 29 de octubre de $1473^{144}$, Juan II entraba como triunfador en Barcelona, instalado en una engalanada carroza de la cual tiraban cuatro caballos blancos, en lo que era una imagen que recordaba poderosamente la de su hermano, Alfonso el Magnánimo, en su ingreso solemne en Nápoles, en 1443, tras la conquista de dicha ciudad ${ }^{145}$. Nada más atravesar el portal de Sant Daniel, a la sombra de un palio cuyas varas ya no sostenían exclusivamente los representantes de la ciudad, sino también miembros de la nobleza afines al monarca, Juan II se había encontrado -otra novedad- con la procesión del clero de la Catedral y, descendiendo de su honorífica atalaya móvil, había orado ante la Vera Cruz. De nuevo sobre su carroza, el rey había sido conducido hasta la plaza del Born para contemplar el paso de los oficios artesanos y, tras ello, se había desplazado hasta la Seu por el itinerario habitual que discurría por las calles Ample y del Regomir ${ }^{146}$. Concluido el ritual religioso en el interior del templo, el soberano había sido acompañado, por último, hasta sus estancias en el Palacio Episcopal.

Ceremonia reconocible -puesto que de ello dependía su efectividady, al mismo tiempo, única y singular -confirmando, una vez más, la voluntad histórica de estas celebraciones-, la entrada de Juan II en Barcelona en 1473 venía a poner punto final a un período de una intensidad escénica poco común en la historia de la ciudad, acorde a la magnitud del drama político que en ese tiempo se había representado en Cataluña. Y lo hacía de una manera que no sólo reflejaba la resolución del conflicto a favor del soberano -lejos ya los días en que el príncipe de Viana, en 1461, era recibido solemnemente por una Barcelona en armas, mientras el propio Juan II se veía privado de poder entrar siquiera en el Principado-, sino que también parecía anunciar una nueva

\footnotetext{
${ }^{144}$ Curiosamente, ninguno de los dietarios barceloneses -ni el municipal ni el de la Generalitat, ni siquiera el particular de Jaume Safont- registran noticia alguna sobre esta entrada. Tan sólo el Memorial Històric de Joan Francesc Bosca -ciudadano de Barcelona y activo partidario del bando realista durante la Guerra Civil Catalana- recoge una breve descripción del evento, aunque sin precisar la fecha exacta del mismo (Joan Francesc Boscè, Memorial Històric, Barcelona, 1977, pp. 93-94). Posteriormente, Jerónimo Zurita reutilizó dicha descripción en sus Anales de la Corona de Aragón, señalando, eso sí, su deuda con Boscà (Jerónimo ZurITA, Anales de la Corona de Aragon, 9 vols., Zaragoza, vol. 7, pp. 729-730). Es a partir de la información contenida en una de las dos ordenanzas municipales con las que se anunció la entrada de Juan II cuando podemos asegurar con exactitud que la ceremonia tuvo lugar el 29 de octubre de 1473: «que com aprés que, per crida, fonch notifficada la entrada per nostre rey e senyor en la present ciutat fahedora lo die de demà, que serà dijous, lo dit senyor, per certs respectes,... haje del-liberat la dita sua entrada ésser differida fins a divendres» (AHCB, CC, Ordinacions, IV-10, f. 45r-v. 1473, octubre, 27).

${ }^{145}$ Imagen que, en cierto sentido, convierte en legítima la duda acerca de si el triunfo que, ese día, se celebraba en Barcelona tenía que ver estrictamente con lo acaecido en Perpiñán en 1473 o si, por el contrario, remitía diferidamente a la realidad de lo sucedido -pero nunca explicitado a nivel ceremonial- en la propia ciudad catalana en noviembre de 1472. Tanto una como otra evocaban, a su vez, el espíritu y la iconografía del triumphus, ceremonia clásica del mundo romano que, de hecho, se encuentra en el origen de las prácticas de recepción solemne bajomedievales. Acerca de la transmisión de dicho ritual desde la Antigüedad hasta la Edad Media, véase Michael MCCORMICK, Eternal Victory. Triumphal Rulership in Late Antiquity, Byzantium, and the Early Medieval West, Cambridge, 1986.

${ }^{146} \mathrm{El} 26$ de octubre de 1473 , una primera ordenanza municipal ponía sobre aviso a la población de Barcelona acerca del previsto desarrollo de la entrada de Juan II: «entrant per lo portal de Sant Daniel, vindrà en la plaça del Born e, passant per la sglèsia de Sancta Maria de la Mar, procehirà per lo carrer Ample e, per lo Regomir, vindră e entrerà en la Seu» (AHCB, CC, Ordinacions, IV-10, f. 44v).
} 
distribución de fuerzas en la relación entre la ciudad y la monarquía ${ }^{147}$. Por uno u otro motivo, las ceremonias de entrada real en Barcelona, en adelante, no volverían jamás a ser lo mismo ${ }^{148}$.

\section{CONCLUSIÓN}

El recorrido por las ceremonias de entrada real celebradas en Barcelona entre 1461 y 1473 , las cuales hemos intentado describir -a fin de poner en evidencia la existencia en la ciudad de un modelo local básico reconocible para este tipo de eventos- y analizar -en aras a determinar la posible relación entre las variaciones de dicho modelo y el contexto histórico en el que éstas se producen-, nos ha permitido mostrar un ritual celebrativo vivo y cambiante, de una complejidad interpretativa que va mucho más allá de la mera lectura escénica, y que es, al mismo tiempo, señal de identidad -en tanto que tradición propia de una ciudad-, práctica política -al expresar y graduar vínculos entre ésta y la monarquía- y lenguaje orgánico -en la medida en que pone en contacto al municipio con lo que se halla en el exterior de sus muros protectores. Ritual que, por otra parte, no ha de contemplarse como esencialmente ajeno a las dinámicas ceremoniales que todo municipio bajomedieval es susceptible de generar en su devenir cotidiano, sino que, por el contrario, necesita ser estudiado como una manifestación más -excepcional y extraordinaria, eso sí- de dicha capacidad.

El hecho de situar este estudio en el marco cronológico de la Guerra Civil Catalana nos ha posibilitado, por otra parte, percibir con mayor intensidad la interacción entre ceremonia y realidad política, al comprobar cómo las vicisitudes del enfrentamiento bélico incidían en la forma tomada por las diversas recepciones ofrecidas por la ciudad de Barcelona a la monarquía en estos años, y al descubrir que éstas, a su vez, no sólo podían, en cierta

\footnotetext{
${ }^{147}$ En diciembre de ese mismo año, Juan II, como "señor de todas las ceremonias", intervendría personalmente en la organización de la tradicional procesión que, anualmente, se celebraba en la fiesta de la Concepción, con el fin de conseguir que determinados miembros de la nobleza y del clero - al igual que había sucedido respecto de los portadores del palio en su entrada en Barcelona- pudieran participar en ella ocupando lugares de privilegio que, hasta eșe momento, estaban reservados a personalidades de la ciudad designadas por el consistorio municipal: «E nos meravell algu la present scriptura e serimonia legint si veu cosa no acustumada car comtes ne ecclesiastichas personas en semblants coses no son acustumades esser collocades sino son strenges o missatges, pero lo Senyor Rey qui es cap de les serimonies ell ab propria persona ho volgue e ordona, e axi covench affer se voluntat» (Manual de Novells Ardits, vol. II, pp. 518).

${ }^{148}$ La celebración de la entrada sọlemne de Fernando II en Barcelona, en 1479, a pesar de retomar el modelo ceremonial previo a la Guerra Civil Catalana -recuperando, incluso, la celebración de justas urbanas, totalmente olvidadas desde la entrada de Juan II en 1458-, fue, sin embargo, escenificada en dos días no consecutivos, «per no donar tedi al dit senyor», al tiempo que incorporaba una procesión idéntica a la de la fiesta del Corpus como parte relevante del evento (AHCB, CC, Deliberacions, II-24, f. 175r-v. 1479, julio, 6). Posteriormente, la recepción ofrecida por la ciudad a Isabel I de Castilla, en 1481, supondría un punto de inflexión definitivo en la historia de la entrada real en Barcelona, convirtiéndose, a su vez, en modelo de las ceremonias venideras del siglo XVI (Véase, para un breve análisis sobre la trascendencia de dicha entrada, M. RAUFAST, Imagenes para una ceremonia).
} 
manera, "explicar" -en tanto que reflejo- el propio conflicto, sino que también conseguían desempeñar un papel como agentes activos dentro de él. Igualmente, hemos querido aprovechar ese preciso contexto para ir un poco más allá y, sin perder de vista la ciudad de Barcelona, realizar una reflexión inicial previa -que se nos antojaba pertinente y casi obligada- sobre la conflictividad interna inherente a toda ceremonia cívica urbana, planteando - una vez más- la estrecha relación entre la escenificación de todo orden social y la incesante tensión -en ocasiones latente, en otras explícita- sobre la cual dicho orden está sostenido.

Fecha de recepción del artículo : mayo 2008.

Fecha de aceptación y versión final: septiembre 2008. 


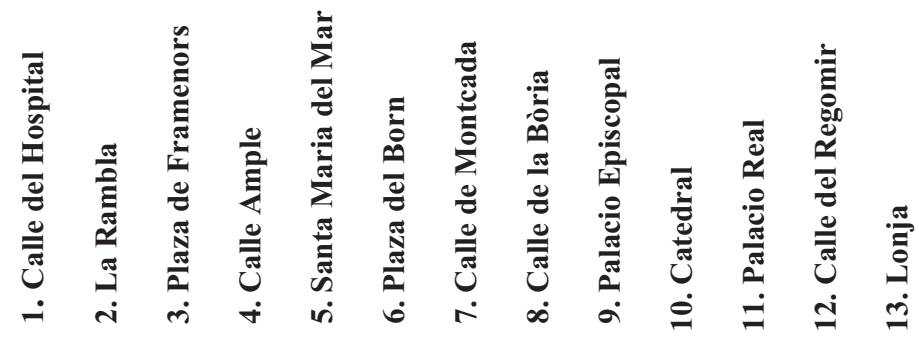

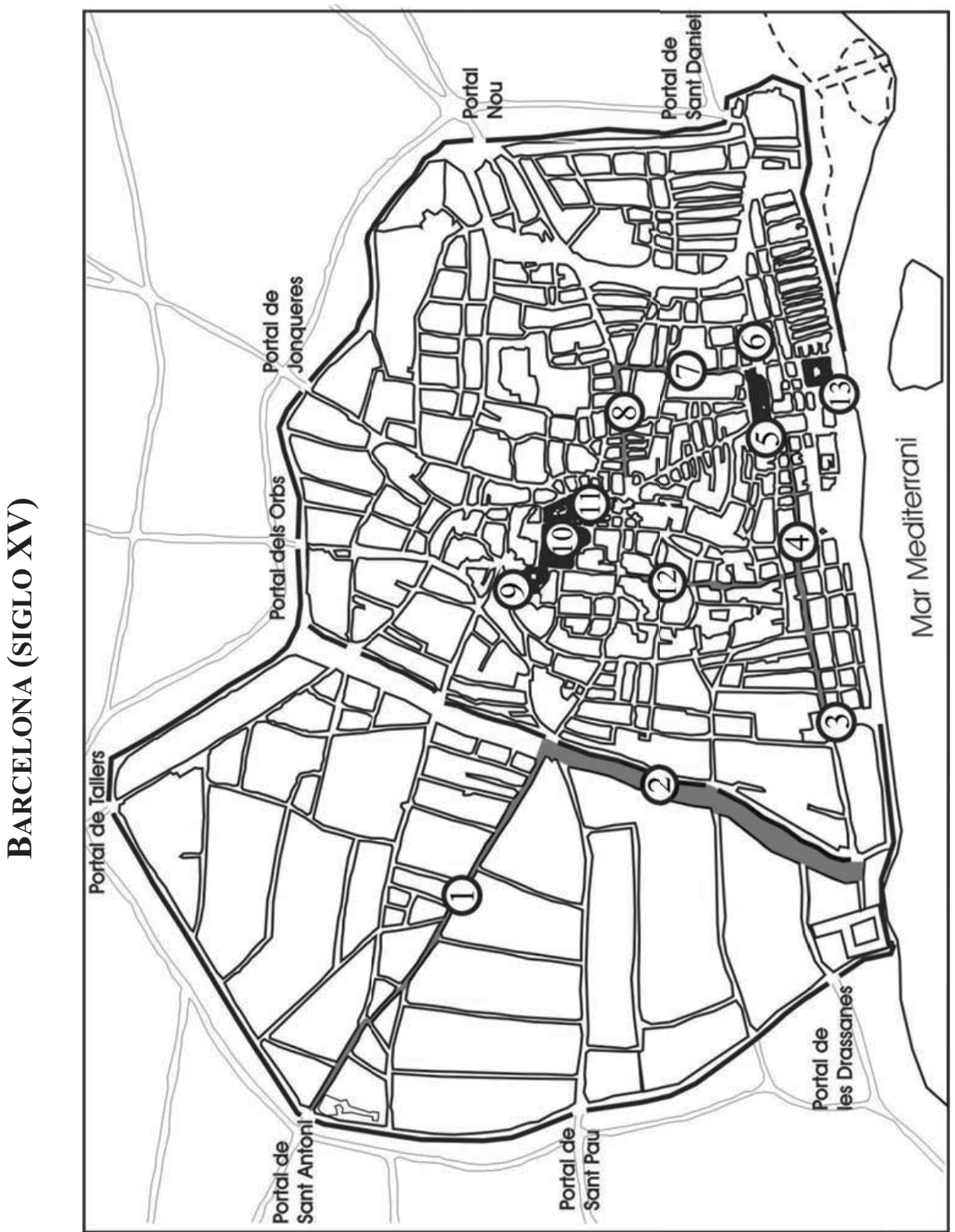

